Carmen Soares

Irene Coutinho de Macedo (coords.)

\title{
ENSAIOS SOBRE
}

\section{Património Alumientar LUSO-BRASILEIRO}

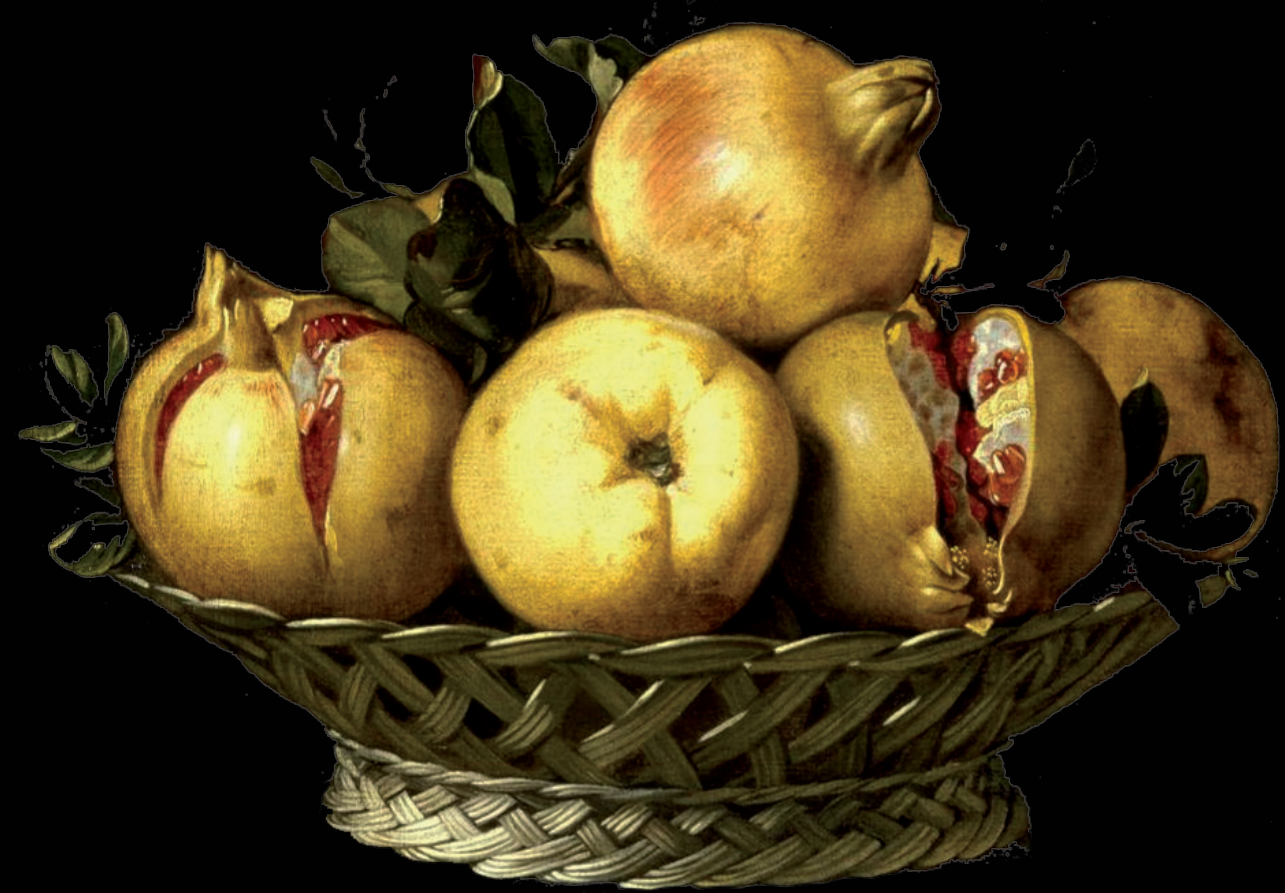

IMPRENSA DA UNIVERSIDADE DE COIMBRA COIMBRA UNIVERSITY PRESS 

SÉrie DIAITA

Scripta \& Realia 


\section{Estruturas Editoriais}

SÉrie DIAITA

SCRIPTA \& REALIA

ISBN: 978-989-26-0885-3

Diretor Principal

Main Editor

Carmen Soares

Universidade de Coimbra

\section{Assistentes Editoriais}

Editoral Assistants

João Pedro Gomes

Universidade de Coimbra

\section{Comissão Científica}

EDITORIAL BOARD

Adeline Ruquoit

CNRS-Paris, França

Frederico Lourenço

Universidade de Coimbra, Portugal

Ana Maria Maud

Henrique Soares Carneiro Universidade de Sáo Paulo, Brasil

Ariel Guiance

Maria José Azevedo Santos

Universidad de Córdoba, Argentina

Universidade de Coimbra, Portugal

Carlos Fabião

Maria José García Soler

Universidade de Lisboa, Portugal

Francisco Contente Domingos Univerdidade do País Basco, Espanha

Universidade de Lisboa, Portugal

Nilma Morcef de Paula Universidade Federal do Rio de Janeiro, Brasil 


\section{ENSAIOS SOBRE PATRIMÓNIO ALIMENTAR LUSO-BRASILEIRO}

\section{Carmen Soares e Irene Coutinho de Macedo (coords.)}

IMPRENSA DA UNIVERSIDADE DE COIMBRA

COIMBRA UNIVERSITY PRESS

ANNABLUME 


\title{
SÉRIE DIAITA
}

Scripta \& REALia

Título Title

Ensaios sobre património Alimentar Luso-brasileiro

Studies on Luso-brazilian Food Heritage

Coords. Eds.

Carmen Soares e Irene Coutinho de Macedo

Editores Publishers

Imprensa da Universidade de Coimbra

Coimbra University Press

www.uc.pt/imprensa_uc

Contacto Contact

imprensa@uc.pt

Vendas online Online Sales

http://livrariadaimprensa.uc.pt

Coordenação Editorial Editorial Coordination

Imprensa da Universidade de Coimbra

Conceção Gráfica Graphics

Rodolfo Lopes, Carlos Costa, Nelson Ferreira

Infografia Infographics

Nelson Ferreira

\author{
Annablume Editora * Comunicação \\ www.annablume.com.br \\ Contato Contact \\ @annablume.com.br
}

Imagem da capa Cover's image

Juan van der Hamn [Public domain],

via Wikimedia Commons

Impressão e Acabamento Printed by

Simōes \& Linhares, Lda. Av. Fernando Namora, n.o 83

Loja 4. 3000 Coimbra

ISBN

978-989-26-0885-3

ISBN Digital

978-989-26-0886-0

DOI

http://dx.doi.org/10.14195/978-989-26-0886-0

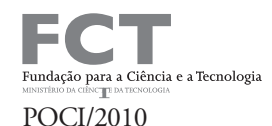

$\mathrm{POCI} / 2010$

Depósito Legal Legal Deposit

\section{(C) Outubro 2014}

Annablume Editora * Săo Paulo Imprensa da Universidade de Coimbra Classica Digitalia Vniversitatis Conimbrigensis http://classicadigitalia.uc.pt

Centro de Estudos Clássicos e Humanísticos da Universidade de Coimbra 


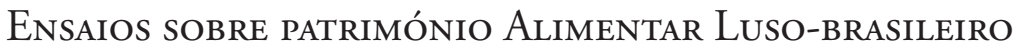 Studies on Luso-brazilian Food Heritage
}

Coords. EDs.

Carmen Soares \& Irene Coutinho de Macedo

Filiaçấo Affiliation

Universidade de Coimbra \& Centro Universitário SENAC-São Paulo

\begin{abstract}
Resumo
O presente livro oferece uma abordagem diacrónica de elementos patrimoniais de alguns dos padróes alimentares dos Portugueses e da forma como a receção e fusão dos mesmos se dá na cultura brasileira. A obra constituise de quatro partes, formadas por capítulos agregados por épocas históricas (da Antiguidade Clássica à Época Contemporânea).

Assim os capítulos reunidos na I Parte apresentam estudos sobre hábitos de consumo e rituais de convivialidade oriundos das duas grandes civilizaçôes fundadoras da Europa, a grega e a latina, e têm por objectivo demonstrar como algumas práticas, hoje tidas irrefletidamente por hábitos dos tempos contemporâneos, são muito mais do que isso. Constituem a ligação do homem atual a um passado distante, a herança mediterrânea antiga, ainda assim modeladora da sua identidade.

$\mathrm{Na}$ Parte II o enfoque orienta-se para o universo da alimentaçấo na Idade Média, quer abordando questôes de ordem moral/religiosa, quer debruçando-se sobre dois dos universos mais documentados para a época em questão: a mesa dos reis e a das ordens monásticas.

Segue-se a Parte III, que permite ao leitor compreender, com base no exemplo da mesa régia e de um colégio universitário, alguns dos aspetos fundamentais da transição da Idade Média para a Idade Moderna. Os Descobrimentos portugueses provocaram um enorme impulso na produção de açúcar e, consequentemente, no fabrico, comércio e consumo de doces, temática central nesta parte da obra.

$\mathrm{Na}$ Parte IV, cria-se um espaço de reflexão sobre o contributo da herança cultural portuguesa na construção de um discurso sobre a cozinha brasileira e no aparecimento na sociedade, sob a influência colonial, de mitos, crenças e tabus associados ao aleitamento materno (um tema geralmente marginalizado no âmbito da História da Alimentação).
\end{abstract}

\section{PaLaVras-chave}

História da Alimentação, Património Alimentar, Dieta Mediterrânea Antiga, Idade Média, Época Moderna, Época Contemporânea, Portugal, Brasil, Lusofonia

\footnotetext{
Abstract

In this book the reader will find a diachronic analysis of some Portuguese food heritage patterns and the way they were received and adapted in the Brazilian culture. The work is organized in four parts, each one with several chapters, approaching food heritage from Classical Antiquity to the present.

Part I concerns eating practices and hospitality in the Greek and Roman worlds, the two great civilization founders of Europe. The main goal of its chapters is to demonstrate that some contemporary food habits are very strongly connected to a Classical Mediterranean heritage. The underlining of these cultural bounds between nowadays food culture and its past allows us to understand the real importance of food on the shaping of everybody's cultural identity.

Part II focus on food in the Middle Ages, particularly on its moral and religious issues. The social contexts considered are the king's table and the monastic communities, because those are the most well documented realities we have.

Part III discusses the transition from the Middle Ages to the Modern Era, taking as example, once again, the food habits of the royal family and also of a university college. With the Portuguese Discoveries came a great
} 
impulse on sugar production and, consequently, on the manufacturing, commerce and consumption of sweets, a thematic central on this part.

Part IV is dedicated to the contribution of Portuguese heritage in structuring a discourse on Brazilian cuisine and to the early appearance on the Brazilian colonial society of myths, beliefs, and taboos concerning breastfeeding (a field of research usually marginal on Food History).

\section{Keywords}

Food History, Food Heritage, Ancient Mediterranean Diet, Medieval History, Modern History, Contemporary History, Portugal, Brazil, Lusophone World 


\section{Coordenadoras}

Carmen Soares é Professora Associada com agregação da Universidade de Coimbra (Faculdade de Letras). Tem desenvolvido a sua investigação, ensino e publicaçóes nas áreas das Culturas, Literaturas e Línguas Clássicas, da História da Grécia Antiga e da História da Alimentação. Na qualidade de tradutora do grego antigo para português é co-autora da tradução dos livros V e VIII de Heródoto e autora da tradução do Ciclope de Eurípides, do Político de Platão e de Sobre o afecto aos filhos de Plutarco. Tem ainda publicado fragmentos vários de textos gregos antigos de temática gastronómica (em particular Arquéstrato). É coordenadora executiva do curso de mestrado em "Alimentação - Fontes, Cultura e Sociedade" e diretora do mestrado em Estudos Clássicos. Investigadora corresponsável do projecto DIAITA-Património Alimentar da Lusofonia (apoiado pela FCT, Capes e Fundação Calouste Gulbenkian: http://www.uc.pt/iii/research_centers/CECH/projetos/ diaita)

CV completo disponível na plataforma DeGóis: http://www.degois.pt/visualizador/curriculum.jsp?key=7724126685525965

Irene Coutinho de Macedo é graduada em Nutrição e mestre em Nutrição Humana Aplicada pela Universidade de São Paulo e especialista em Educação em Saúde pela Universidade Federal de São Paulo. Docente e pesquisadora do Centro Universitário Senac e da Universidade São Judas Tadeu, nos seguintes temas: educação alimentar e nutricional, nutrição e cultura. É coordenadora do curso de Bacharelado em Nutrição do Centro Universitário Senac, membro da equipe editorial da Revista Contextos da Alimentaçáo (ISSN 2238-4200) e colaboradora do projeto DIAITA - Património Alimentar da Lusofonia

Currículo Lattes: http://lattes.cnpq.br/2236612357599334 


\section{EDITORS}

Carmen Soares: Associate Professor of the University of Coimbra (Faculty of Letters). Teaching activities, research interests and publications: Classics, Ancient Greek History and Food History. Author of several books and papers and translator into Portuguese of Herodotus (books V and VIII), Euripides (Cyclops), Plato (Statesman), Plutarch (On Affection for Offspring) and fragments of gastronomic Greek literature (Archestratus, Life of Luxury). Executive Coordinator of the MA in Food: Sources, Culture and Society and Coordinator of the MA in Classical Studies. One of the main investigators of the DIAITA Project: Lusophone Food Heritage supported by FCT, Capes and Calouste Gulbenkian Foundation (http://www.uc.pt/en/iii/research_centers/CECH/projetos/diaita) CV: http://www.degois.pt/visualizador/curriculum.jsp?key=7724126685525965

Irene Coutinho de Macedo received her bachelor's degree in Nutrition and master's degree in Applied Human Nutrition from Universidade de São Paulo. She also has a specialist certificate in Education and Health from Universidade Federal de São Paulo. She is a professor and researcher in nutritional education and nutrition and culture of Centro Universitário Senac and Universidade São Judas Tadeu. Currently coordinates de Bachelor Degree in Nutrition of Centro Universitário Senac. Member of the editorial board of the peer-reviewed publication Food Contexts (ISSN 2238-4200) and collaborator of DIAITA - Lusophone Food Heritage.

Lattes profile: http://lattes.cnpq.br/2236612357599334 


\section{SuMÁRIO}

Prefácio

Parte I: Origens Mediterrâneas do Património Alimentar Luso-brasileiro

Pão e vinho sobre a mesa. Um “clássico” da Alimentação Portuguesa

(Bread \& wine: a classical motif of the Portuguese Food)

Carmen Soares

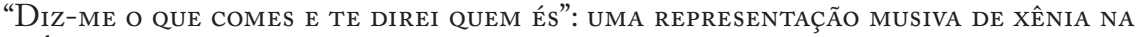
África Romana

("Tell me what you eat and I will tell you who you are": a mosaic depiction of xenia in

Roman Africa)

Regina Maria da Cunha Bustamante

Parte II: Identidades Alimentares da Idade Média

DE SPIRITU GASTRIMARGLAE - DisTOPIA ALIMENTAR E GULA NA REPRESENTAÇÃo DO INFERNO NA TRADIÇÃO MORAL OCIDENTAL

(De Spiritu Gastrimargiae - food distopia and gluttony in the representation of hell in

European moral tradition)

Paula Barata Dias

A Mesa do rei de Avis. Espaços, oficiais, alimentos e cerimoniais

(The table of John I, king of Avis: spaces, servants, food, ceremonial)

Maria Helena da Cruz Coelho

Alimentar a cidade de Coimbra na Baixa Idade Média: notas sobre os ALIMENTOS, AS ESTRUTURAS DE TRANSFORMAÇÃo ALIMENTAR E OS OFÍCIOS

(Feeding the city of Coimbra in the Late Middle Ages: notes on food production and processing structures and professional occupations)

Maria Amélia Campos

Parte III: Identidades Alimentares da Época Moderna

Aspectos da mesa do rei. Entre a Idade Média e a Época Moderna

(The king's table as an interdisciplinary field. Between Medieval and Modern times)

Ana Isabel Buescu

Confeiteiros na Época Moderna: Cultura Material, Produção e

Conflituosidade

(The Confectioners in the Modern Era: Material Culture, Production and Bickering) 165 Isabel M. R. Mendes Drumond Braga 
O CONTRIBUTO DAS FONTES PALEOGRÁFICAS PARA O ESTUDO DA HISTÓRIA DA alimentação: O caso do Livro de Superintendência de Cozinha do Real Colégio de São Pedro de Coimbra (séc. XVII)

(The contribution of paleographic sources for the study of history of food: The case of the Food's Superintendent Book of the Real Colégio de São Pedro de Coimbra (XVII century))

Guida Cândido

Uma Doce Viagem: Doces e Conservas na correspondência de D. Vicente Nogueira com o Marquês de Niza (1647-1652)

(A Sweet Journey: Lisbon's Confectionery in the correspondence between D. Vicente Nogueira and the Marquis of Niza (1647-1652))

João Pedro Gomes

Parte IV: Heranças portuguesas da gastronomia e nutrição brasileiras

Luis da Câmara Cascudo e a ementa portuguesa: a contribuição de Portugal NA CONSTRUÇÃO DO PENSAMENTO SOBRE A COZINHA BRASILEIRA

(Luís da Câmara Cascudo and the portuguese ementa: contributiond from Portugal for the construction of a Brazilian cuisine thought)

Leila Mezan Algranti \& Wanessa Asfora

Aspectos Culturais na prática do aleitamento materno decorrentes DA HERANÇA HISTÓRICA DO BRASIL COLÔNIA

(Cultural aspects of breastfeeding practices influenced by Brazil's colonial period historical heritage)

Irene Coutinho de Macedo

Bibliografia

Fontes

Estudos

ÍNDICE ONOMÁSTICO

Antropónimos

Topónimos/Etnónimos

Alimentar

Produção

Ofícios/Mesteres

Índice Comum 


\title{
A Mesa do Rei de Avis. ESPAÇOS, OFICIAIS, ALIMENTOS E CERIMONIAIS (The table of John I, king of Avis: spaces, servants, food, ceremonial)
}

\author{
Maria Helena da Cruz Coelho \\ Universidade de Coimbra (coelhomh@gmail.com)
}

Resumo: D. João I e a corte régia itinerou pelo reino por motivos de guerra ou em tempo de paz devido a exigências várias, das políticas e cerimoniais às lúdicas e pessoais. Aposentou-se, comendo e dormindo, em diversas instalações, entre castelos, mosteiros, e casas senhoriais de nobres e clérigos. Teve, porém, os seus próprios paços, onde mais demoradamente estanciou, bem como também percorreu os da rainha, e neles nos deteremos para conhecer mais de perto a sua cozinha e mesa. Constituídas as casas do rei e da rainha, em 1387, dispomos de um arrolamento sobre os seus vassalos e oficiais, que nos permite dar conta do número e função dos oficiais afectos à cozinha e à mesa de $\mathrm{D}$. João I e de $\mathrm{D}$. Filipa de Lencastre. Chegaram ainda até nós duas cartas de quitação que nos relatam algumas compras efectuadas pelos oficiais régios de objectos de mesa e sobretudo de bens alimentares. Com estas fontes e com as narrações cronísticas tentaremos acercarmo-nos dos pratos, dos gostos, dos sabores, da ética e etiqueta da mesa quotidiana ou festiva do rei de Avis.

Palavras-chave: corte régia medieval, palácio real, oficiais da cozinha e da mesa régia, mantimentos régios, cerimonial e da etiqueta da mesa do rei e da rainha.

Авsтract: John I and the Royal Court travelled throughout the Kingdom for reasons of war or, in peacetime, due to various requirements, from political and ceremonial to personal and leisure ones. They stayed, eating and sleeping, in several dwellings, including castles, monasteries and manor houses of nobles and clerics. The king had, however, his own palace, where he remained for longer periods of time; he also stayed at the Queen's residence. We will focus on both royal dwellings in order to look more closely at their kitchen and table. The Houses of the King and of the Queen were established in 1387, and we have some inventories of their vassals and servants that allow us to give an account of the number and function of officers assigned to the kitchen and table of King John I and Philippa of Lancaster. We came also to know two letters of discharge that report some purchases of tableware and, above all, of food, made by the royal servants. Through these sources and using chronicle narratives we will try to approach the dishes, tastes, flavours, etiquette and manners of the everyday or festive day table of the King of Avis.

KEYwORDs: medieval royal court, royal palace, servants of the royal kitchen and table, royal victuals, ceremonial and etiquette of the table of medieval kings and queens

\section{ITINERÁRIOS E APOSENTOS}

Como bem sabemos, os monarcas e a corte régia eram, em tempos medievais, itinerantes, uma condição intrínseca da própria realeza, que lhe 
permitia uma mais cabal apreensão do espaço e da gente do reino, como não menos uma exibição e propaganda do seu supremo poder. As deslocações dos monarcas eram exigidas por motivos de guerra, por acontecimentos políticos, como a realização de Cortes, pela presença em cerimónias ou actos solenes, pela fuga a pestes, pelas actividades lúdicas, como a caça, ou por certas deslocações sazonais da sua preferência ${ }^{1}$.

D. João, muito em particular compelido a uma significativa actividade bélica nos anos iniciais do seu reinado, teve de percorrer largos e longos percursos, dentro e fora do reino. Todavia, o seu demorado reinado contou também com muitas etapas de maior abrandamento na itinerância, e mesmo, a partir de certa data, de uma acentuada sedentarização ${ }^{2}$.

A partir da cidade de Lisboa, que o elevou ao poder, em campanhas de guerra mais ou menos activas até aos finais do século $\mathrm{XV}$, circulou entre o Minho, Trás-os-Montes e Beira, mas desceu também ao Alentejo e saiu mesmo do reino, na campanha luso-inglesa, avançando pela província de Salamanca, como noutras expedições conheceu vilas e cidades galegas ou estremenhas ${ }^{3}$.

No dobrar da centúria, firmada a paz em 1402, renovada por sucessivos tratados, o rei, já em idade madura, com cerca de 45 anos, abrandou a itinerância e optou mais significativamente pela sedentarização, ainda que em 1415 rumasse até Ceuta. A corte régia fixou-se, então, em torno do triângulo urbano e comercial de Lisboa, Santarém e Évora e, a partir de meados da década de 20, era quase apenas nesses locais que vivia o monarca com os seus familiares, vassalos e clientelas.

\subsection{Paços}

Toda esta intensa mobilidade da corte régia nos leva a problematizar as condições materiais da sua aposentadoria e alimentação. Primeiro do monarca e seus privados, e, em seguida, do seu maior ou menor séquito, consoante as circunstâncias ${ }^{4}$.

Recorriam os monarcas, na sua itinerância, a diversas instalações para se acomodarem. Antes de mais a espaços militares de castelos, por vezes associados a alcáçovas, residências do poder militar. D. João I muito se terá aproveitado deles quando circulou por terras nortenhas de Entre Douro e Minho ou pelas raianas e interiores de Trás-os-Montes e Beiras. Ao mesmo tempo serviam-se de espaços religiosos, em particular de mosteiros,

${ }^{1}$ Leia-se Gomes 1995: 241-255.

${ }^{2} \mathrm{O}$ itinerário de D. João I, elaborado a partir dos registos de chancelaria (que têm uma natureza própria e por vezes apresentam lacunas e deficiências) foi estudado por Moreno 1988.

${ }^{3}$ Uma síntese da itinerância de D. João I nos seus percursos "de andada" ou "de estada " se encontra na obra de Coelho 2008.

${ }^{4}$ Cfr. Gomes 1995: 255-285. 
principalmente em áreas onde outras possibilidades de instalação não se apresentavam, tendo o rei de Avis recorrido, no norte, aos de Grijó, Paço de Sousa e Santo Tirso e, no centro-sul, à casa beneditina de Semide e às cistercienses de Alcobaça, Almoster e Odivelas, à franciscana de Alenquer e à dominicana da Batalha. E não hesitaram mesmo em acomodarem-se em residências privadas de senhores eclesiásticos ou laicos, como fez D. João I quando se recolheu nos paços do arcebispo D. João Esteves de Azambuja, nos arrabaldes de Santarém, ou na quinta do seu guarda-mor, Martim Afonso de Melo, em Água de Peixes, no Alvito.

Mas, em certas cidades e vilas, enquadradas em ambientes mais urbanizados ou campestres, os soberanos dispunham também de paços, de residências próprias 5 . Localizavam-se, no geral, em lugares mais estratégicos e intensamente percorridos pela itinerância da corte régia ou de permanência prolongada. Muitos seriam apenas construções modestas e pouco imponentes, que estavam à guarda de um oficial próprio, o paceiro, apenas se destacando uns quantos.

Em Coimbra, Santarém e Lisboa dispunha o monarca de residência nas suas alçácovas, encimadas em estratégicas áreas defensivas e amuralhadas, que, por isso mesmo, eram também de incómodas acessibilidades ${ }^{6}$.

Assim em Coimbra, o soberano poderia ter, por vezes, preferido os paços de Santa Clara, mas a região oferecia-lhe muitas outras possibilidades ${ }^{7}$, desde logo em Tentúgal, onde o infante D. Pedro, duque de Coimbra, renovou o paço real com a sua capela, e aí estanciou muitas vezes D. João I.

Mais para sul, por todo o litoral estremenho, contava o rei com castelos e também com paços, sobretudo os que a rainha possuía nas suas terras aí localizadas. O rei de Avis terá assim ocupado os castelos de Leiria e Alenquer ou os paços da rainha em Torres Vedras, os paços do rei na alcáçova de Óbidos e ainda os que a rainha detinha na vila, adossados ao muro, com capela própria. Deixou, porém, marca mais assinalável em Leiria, onde mandou erguer um paço de quatro pisos, flanqueado por duas torres, servido pela igreja gótica de Nossa Senhora da Pena. No andar nobre, com uma varanda de arcos apontados com vista para a cidade, existiam três salas e três câmaras, espalhando-se pelos demais andares as cozinhas, edifícios de armazenamento e latrinas. Esta residência acastelada oferecia já um certo conforto, com vários

\footnotetext{
${ }^{5}$ Gomes 1995: mapa 3, aponta a localização das residências régias nos séculos XIV e XV. Veja-se também Marques 2010: 93-101 e Silva 2010: 78-97.

${ }^{6}$ As diversas instalações e paços em que se alojou D. João I foram abordadas por Coelho 2008: 215-220, remetendo-se para as abonações bibliográficas aí especificadas.

${ }^{7}$ Desde logo o paço de Botão, em área florestal e cinegética, mas também o castelo e igrejas dentro do recinto amuralhado de Montemor-o-Velho ou, nas terras ducais, qualquer residência em Vila Nova de Anços.
} 
pontos de luz, tectos forrados a madeira, pavimentos ornamentados com cerâmica policromada e vários compartimentos com lareiras, indiciadas por diversas pequenas chaminés.

De mais paços dispunha ainda em Arruda, Aldeia Galega ou em Atouguia. Aqui se encontravam os conhecidos Paços da Serra d'E1-Rei, com vários edifícios e terrenos cercados, em que se criavam mesmo animais exóticos, como cisnes, de que D. João I muito disfrutou em repousantes estadias.

Em Santarém, para além da alcáçova, havia um paço no Chão da Feira, na rua da Porta de Leiria, de mais fácil acesso, que D. João I deverá ter alargado, mandando derrubar casas situadas nessa rua.

Mas as terras estremenhas e ribatejanas eram uma excelente área cinegética, na qual os monarcas tinham muitos reguengos e espaços coutados, com paços nas proximidades, como os da Valada, de Muge ou de Salvaterra. E nas lezírias do Tejo, mandou D. João I construir, nos anos 20 da centúria de Quatrocentos, a sua residência de campo preferida, onde se recolhia frequentemente nos últimos anos da sua vida. Na propriedade que ficou conhecida por Vala de Almeirim ergueram-se, então, grandes paços com amplas salas, câmaras, varandas e jardins de muitas árvores e laranjeiras. Tinham mesmo capela própria, em honra da sua tão venerada Santa Maria. Por todo o circuito envolvente disseminavam-se casas térreas e sobradadas que podiam alojar os cortesãos, bem como se apresentavam campos cultivados, como vinhas, pomares, hortas "com palmeiras e outras árvores", a par de um "cerrado". Num ambiente campestre, assegurava-se, a um tempo, o prazer da convivência com a natureza, a alegria da caça e o deleite de saborear frescas verduras e frutos.

Por sua vez, na grande urbe lisboeta, D. João I dispunha dos Paços do Castelo, residência régia com uma certa monumentalidade, na qual o monarca realizou ainda obras de acrescento e melhoramento. Entre as salas, a principal, com uma área de cerca de $480 \mathrm{~m} 2$, seria assinalável, dispondo igualmente de diversas câmaras e de capela régia de invocação a S. Miguel. Completavam-nos diversas cozinhas e um pátio, o dito "curral" do paço, onde várias edificações se instalavam. 


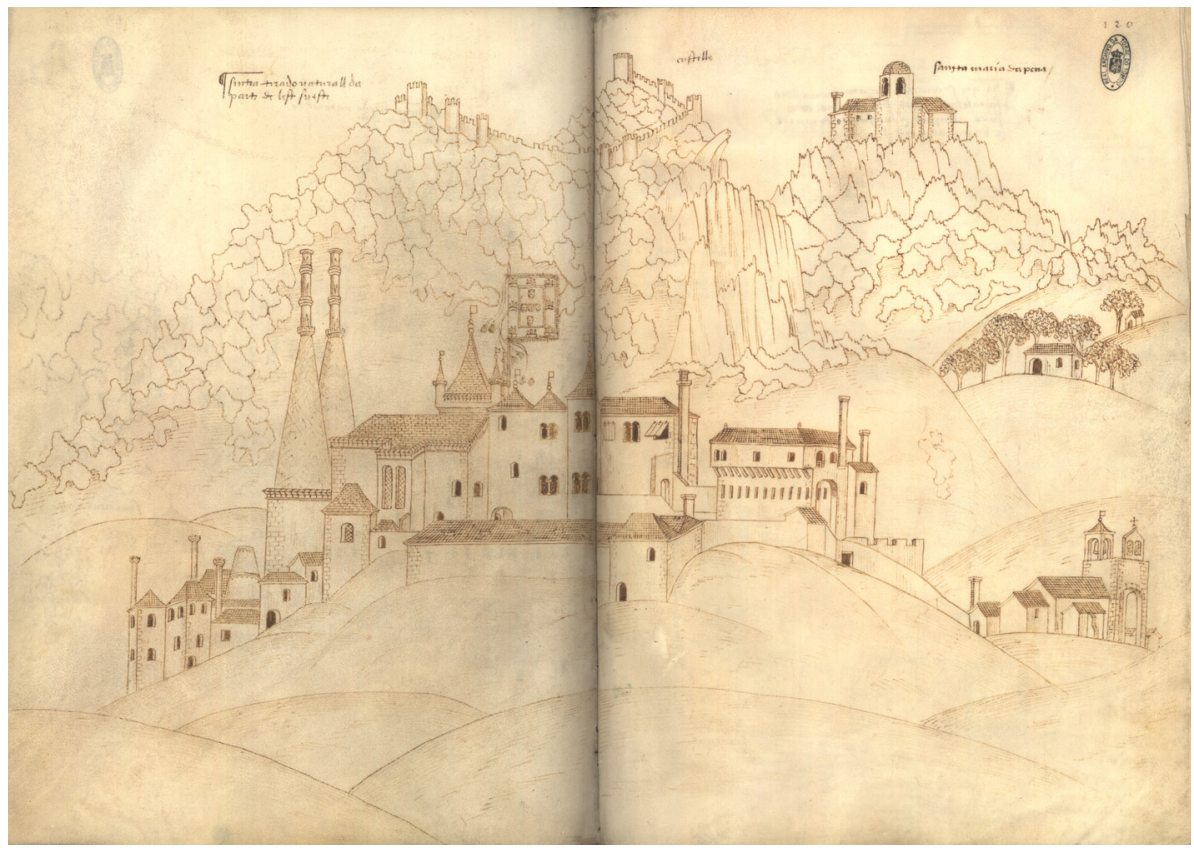

Fig. 1: Palácio da Vila em Sintra (Livro das Fortalezas de Duarte de Armas. Instituto dos Arquivos Nacionais/ Torre do Tombo).

No entorno de Lisboa, disseminados pelo campo, oferecendo calma e lazer, estavam à disposição do rei os paços do Lumiar e de Belas. Todavia, era essencialmente nos paços de Sintra que o monarca se refugiava para fugir ao rigor do Verão, para repousar e para se desenfadar em caçadas. Por isso acrescentou e melhorou esses paços régios da vila, que teriam, no seu tempo, vinte e seis compartimentos, repartidos entre rés-do-chão e primeiro andar, com uma torre, além de dois eirados, cozinhas e capela, numa superfície total pouco inferior a $1000 \mathrm{~m} 2$, como nos dá conta a descrição dos mesmos de D. Duarte no Livro dos Conselhos ${ }^{8}$. Compunham-no grandes salas e várias câmaras, além de espaços interiores mais pequenos e especializados, entre oratórios, guarda-roupas, saquitaria, várias casas para escrivães e privadas.

Teria, pois, capacidade para alojar a corte do rei e da rainha e até a dos infantes com os seus séquitos. Daí a grandeza das suas cozinhas, equipadas com diversas fornalhas e fornos, servidas por duas monumentais chaminés cónicas, que davam saída aos fumos. $\mathrm{E}$ a condução das águas, que corriam da serra para o seu interior, muito facilitaria nelas os afazeres das refeições e da lavagem da utensilagem.

\footnotetext{
${ }^{8}$ Livro dos Conselhos:166-168.
} 
Finalmente, em terras alentejanas, o rei de Avis podia acolher-se nos alcáçares de Évora, Crato, Estremoz, Elvas ou Beja.

Mas justamente em Évora, a terceira cidade-capital da corte, porque a residência fortificada era de reduzidas dimensões, D. João I mandou edificar, logo nos começos do seu reinado, uns paços no mosteiro de S. Francisco, que contava com duas câmaras, com trascâmara e privada, e ainda com um ferragial cercado com horta e laranjeiras.

\section{Oficiais de MESA E COZinha}

Conhecidos os espaços, que podiam dar cama e mesa ao rei, perscrutemos os homens que o deviam servir.

Após o seu matrimónio com D. Filipa de Lencastre, em Fevereiro de 1387, D. João I constituiu a casa do rei e a casa da rainha, que deviam organizar, disciplinar e ser modelo de toda a vida cortesã ${ }^{9}$.

Desta casa do rei e da rainha, bem como da dos infantes, conhecemos para o ano de 1402 um arrolamento do pessoal, que nos dá conta dos moradores na corte, dos membros da mais alta linhagem aos simples oficiais domésticos ${ }^{10}$. A partir dele poderemos acercarmo-nos dos oficiais que tinham funções na aquisição e aprovisionamento dos alimentos, na cozinha e na mesa real.

Mas antes de abordarmos a questão deste oficialato, convém referir alguns aspectos gerais.

Desde logo sabemos que no monarca se condensa uma dupla pessoa, pública e privada, e as instituições e pessoal da corte acompanhavam estes seus diferenciados corpos. No desenho da espacialidade da residência real, era a sala que se traduzia no espaço público de acolhimento, de funcionalidades políticas e de comensalidade, enquanto a câmara correspondia ao espaço íntimo, pessoal e privado da pessoa do rei.

Nos séculos XIV e XV esta separação era já muito vincada, o que se repercutia na vida cortesã. No que à alimentação dizia respeito, como agora nos interessa, cada vez menos o monarca comia com largas assembleias de comensais, mas tomava os alimentos em ambientes restritos, em câmaras, onde poderia privar com a rainha e com alguns vassalos mais íntimos.

O cerimonial e a ritualidade da mesa, com uma significativa presença de convivas, ficaria essencialmente restrito aos ciclos festivos religiosos, pessoais e políticos. Por isso os vassalos régios, fruto da evolução económica e social e até do clima de guerra vivido nestas centúrias, seriam providos ao seu sustento,

\footnotetext{
${ }^{9}$ Veja-se sobre a casa do rei e da rainha no seu conjunto Coelho 2008: 182-191.

${ }^{10}$ Publicado em $M H$,I, doc. 122; Faro 1965: doc. 5, que lhe atribui uma data crítica entre 1405 e 1406.
} 


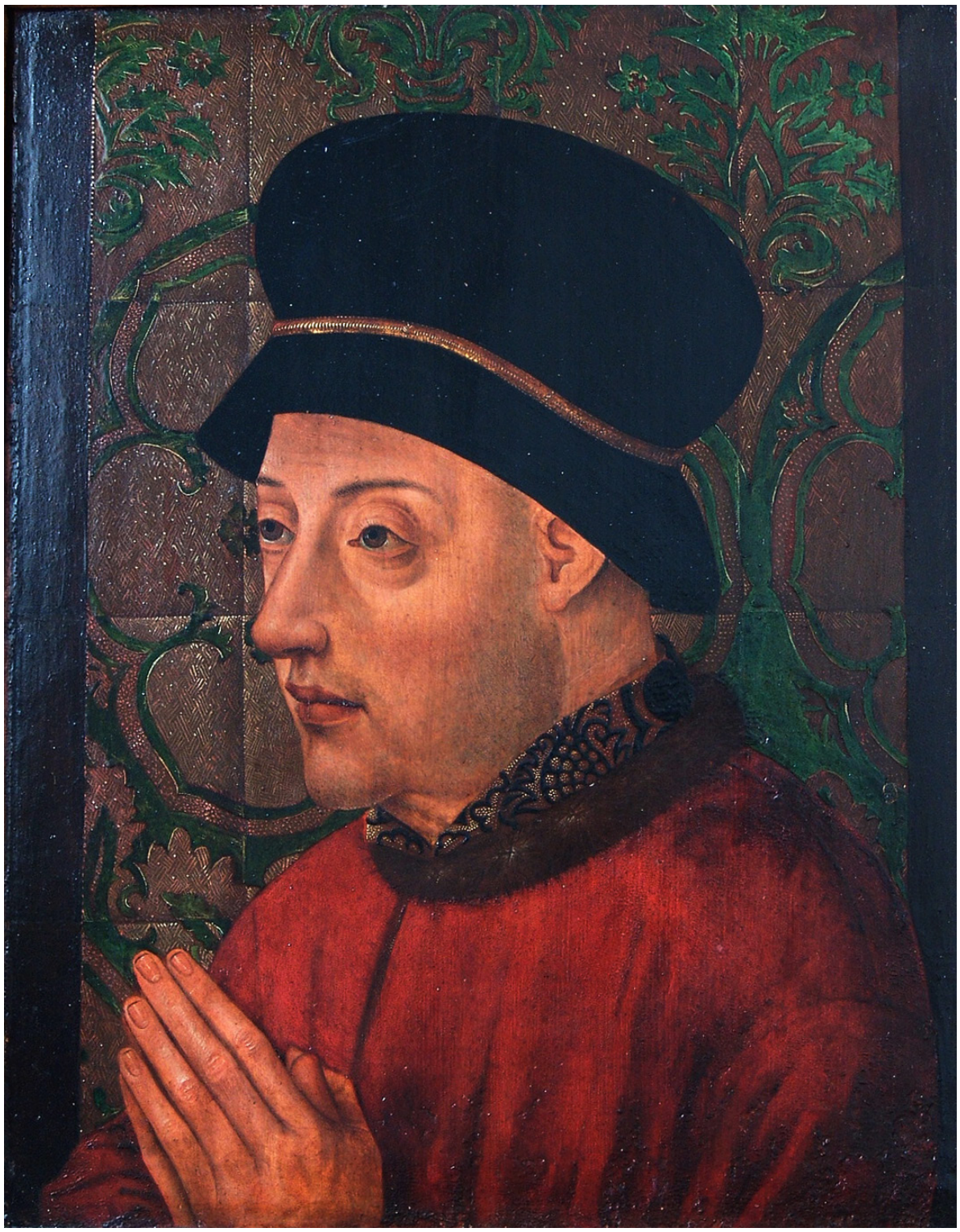

Fig. 2: Retrato de D. João I. Museu Nacional de Arte Antiga. Lisboa. (MNAA 2006 pint.) 
quando estanciavam na corte, essencialmente graças às moradias que recebiam e que lhes garantiam a comida, a bebida e a alimentação das suas montadas ${ }^{11}$.

Neste contexto, compreende-se também que houvesse uma "cozinha del-rei de seu corpo" e uma "cozinha do paço" 12 , o que de igual modo nos remete para a tomada privada de alimentos pelo monarca na sua câmara ou para a sua partilha em banquetes, com vassalos e convivas, na sala ou aula régia.

Ainda como pano de fundo, será de ter em conta que este rol do pessoal da casa real teria sido decretado pelo monarca e seus conselheiros com vista à diminuição das despesas da casa real ${ }^{13}$. Assinadas tréguas com Castela, o monarca procurava "correger" a sua casa, que o passaria a acompanhar e servir de uma forma mais permanente na governação interna do reino. E remodelava igualmente a casa da rainha e também as dos infantes, todos pequenos e de menor idade, não tendo mesmo ainda nascido $\mathrm{D}$. Fernando e já havendo morrido o primogénito D. Afonso ${ }^{14}$.

$\mathrm{Na}$ discriminação dos oficiais da casa do rei, chegam até nós os nomes dos vários oficiais, que cuidavam do sustento real, com seus nomes e respectivos pagamentos ${ }^{15}$, mas sem a especificação, como é evidente, das funcionalidades ou hierarquias ${ }^{16}$. O oficial que superintendia no serviço da mesa do rei, na dispensa ou ucharia e na cozinha era o vedor, pago com 7000 libras, o do rei, e com 9100 libras, o da rainha. Tinha o vedor autoridade sobre todos os demais oficiais, que tentaremos hierarquizar em grande medida pelo montante de numerário que recebiam.

Seguir-se-lhe-ia então o manteeiro, contemplado com 2200 libras, que deveria guardar e dispor da baixela e acessórios necessários à mesa, desde os objectos de prata aos panos. Mas, a par deste, havia ainda um reposteiro ${ }^{17}$,

${ }^{11}$ Sobre esta evolução das moradias leia-se Gomes 2011: 36-42.

${ }^{12}$ Gomes 1995: 307.

${ }^{13}$ Remetemos para a nota crítica que acompanha a publicação do mesmo em $M H$, I, doc. 122.

${ }^{14}$ Este nasce a 29 de Setembro de 1402 e nunca é referido no documento. Por sua vez o primogénito de D. João I e D. Filipa, D. Afonso, tinha já falecido em Dezembro de 1400. São pois citados D. Duarte, D. Pedro, D. Henrique, D. João e a infanta D. Isabel. (Sobre a linhagem do casal de Avis leia-se Coelho: 2008: 158-160). Os infantes só virão a ter casa própria em 1408.

${ }^{15}$ Mas esta domesticidade, dada a sua proximidade com a pessoa do monarca, recebia muitas vezes ainda os seus favores. E assim deparamos na chancelaria com diversas cartas régias que os beneficiavam de variados modos, as quais nos revelam também os seus nomes e cargos. A elas aludiremos a propósito dos diversos ofícios.

${ }_{16}$ Para um confronto com os oficiais da casa real em tempos modernos, consulte-se Pereira 2011: 82-99; e sobre a mesa na Casa dos duques de Bragança, veja-se Cunha 2011: 64-81.

${ }^{17} \mathrm{E}$ haveria um reposteiro-mor, membro da média ou alta nobreza, e outros, vassalos da casa real, que lhe estavam subordinados. Enquanto Mestre de Avis, D. João recompensou os serviços na guerra do seu vassalo Afonso Esteves, que fora reposteiro-mor de D. Fernando, mas abraçara a sua causa, doando-lhe, hereditariamente, a 7 de Outubro de 1384, uma herdade no termo de Azambuja (CHDJ, vol. I, t. 3, doc. 1328). Ao seu reposteiro-mor, Pero Lourenço de Távora, doou D. João I algumas terras no almoxarifado de Chaves, por carta de Guimarães, de 5 de Novembro 
que também cuidaria de certos utensílios específicos da mesa e, por certo, até de alguns alimentos, como a fruta, ou condimentos mais raros, do sal às especiarias e açúcar. Recebia o reposteiro 1200 libras e a ele estava associado um escrivão de reposte, que auferia o mesmo montante.

Um valor superior de 1950 libras cabia ao copeiro, a quem competia zelar pela bebida do rei e acompanhá-lo nas refeições ${ }^{18}$. Já o aprovisionamento da casa real em alimentos pertenceria ao despenseiro, que tinha um escrivão ao serviço da despensa, auferindo o primeiro 1800 libras e o segundo 1200 . Mas também com o abastecimento de víveres estava relacionado o uchão e o comprador que recebiam, cada um, 1200 libras.

Logo depois, num apartado intitulado jograis, enunciavam-se essencialmente servidores da mesa que velavam pelo conforto do ambiente e pelo aparato, etiqueta e ritualidade das refeições conviviais. Assim, para responder à crescente dimensão cerimonial da corte joanina, havia vários jograis ${ }^{19}$, portanto menestréis que animavam festas e banquetes, mas também, num paralelismo com as mais evoluídas cortes europeias, um arauto, ou seja, um oficial de armas com funções cerimoniais e diplomáticas, um trombeteiro, que dirigiria o corpo de músicos, um mestre do relógio e um reposteiro e periliteiro(?), que talvez cuidassem ornamentação e aconchego dos aposen-

de 1385 (CHDJ), vol. I, t. 3, doc. 1087), a terra de Aguiar de Sousa com a total jurisdição, a 3 de Julho de 1387 (CHDJ, vol. II, t. 1, doc. 4), e as honras de Galegos e Lordelo, no termo de Vila Real, com as suas rendas e jurisdições, em 29 de Outubro de 1395 (CHDJ, vol. II, t. 2, doc. 898). Permitiu-lhe ainda que, mediante o pagamento da dízima, pudesse fazer certos canais no rio Douro (CHDJ, vol. IV, t. 1, doc. 137, de Évora, 15 de Abril de 1421) e confirmou-lhe diversas cartas régias de privilégios e doações de $\mathrm{D}$. Fernando e suas, enquanto regente e depois rei, feitas a seus pais, Lourenço Peres de Távora e Alda Gonçalves (CHDJ, vol. IV, t. 1, doc. 144, de Évora, 27 de Abril de 1421). Por sua vez o reposteiro-mor de D. Filipa, Fernão Lopes de Abreu, recebeu de D. João I, enquanto fosse sua mercê, a doação de diversos direitos régios cobrados em Elvas (CHDJ, vol. II, t. 1, doc. 40, de Coimbra, 6 de Fevereiro de 1390). Entretanto, ao reposteiro-mor do infante D. Duarte, o cavaleiro Diogo Fernandes de Almeida, aforou D. João I, por carta de Lisboa, de 1 de Novembro de 1429, uma casa e uma várzea em Abrantes (CHDJ, vol. IV, t. 2, doc. 766). Muito beneficiou também o reposteiro-mor da infanta D. Isabel, Afonso Vasques, homem da criação do rei, doando-lhe hereditariamente bens que comprara por dois contos e umas tantas mil libras, além de lhe conceder a administração do morgado de Óbidos e de lhe legitimar um filho (CHDJ, vol. IV, t. 1, docs. 338, de Évora, 23 de Agosto de 1421; 347, de Montemor-o-Novo, 25 de Setembro de 1421; 259, de Montemor-o-Novo, de 25 de Janeiro de 1422). Um outro seu reposteiro, mas que não seria o principal, Gonçalo da Ponte, filho de um clérigo de Ponte de Lima, viu-se legitimado por carta de Lisboa, de 7 de Maio de 1422 (CHDJ, vol. IV, t. 1, doc. 282).

${ }_{18}$ Ao seu criado e copeiro, Vasco Anes, doou D. João I, enquanto fosse sua mercê, a 20 de Maio de 1388, a renda e os direitos de uma azenha em Atalaia, no termo de Tavira (CHDJ, vol. I, t. 3, doc. 1354). Também ao seu criado e copeiro, Gomes Lourenço, a sua mulher e um filho emprazou o rei de Avis, a 28 de Setembro de 1427, duas quintas e uma granja em Torres Vedras e Atouguia, pela renda anual de 1000 reais brancos (CHDJ, vol. IV, t. 2, doc. 543).

${ }^{19}$ Recebia um 2000 libras e 3 outros 1650 libras cada um. Depois, num acrescento ao rol, referem-se outros dois, sem especificar o seu pagamento. 
$\operatorname{tos}^{20}$. Neste conjunto englobava-se, ainda, o cozinheiro João Martins, que recebia 1000 libras $^{21}$.

Todavia, um acrescento ao pessoal que fora previamente ordenado faz-nos saber que o rei tinha ao seu serviço, para além destes, mais três cozinheiros ${ }^{22}$, dois reposteiros, certamente de câmara, um para ele e outro para os infantes ${ }^{23}$, e, atente-se, 32 moços de câmara ${ }^{24}$, o que nos remete para um crescendo do serviço privado na casa real, onde se desenrolariam muitas das refeições de D. João I.

O rei de Avis manifestava um particular gosto pela arte venatória, sobretudo pela caça grossa de montaria. Logo, na constituição da sua casa, havia um especial arrolamento dos monteiros. $\mathrm{E}$ aí, para além dos ofícios específicos de monteiro, monteirinho, moços do monte, homens de pé, caminheiros, sapateiros, ferradores, azeméis, cavalariços, caçadores, alveitares e falcoeiro, enumerava-se todo um conjunto de serviçais ligados à alimentação, o que nos esclarece sobre a subsistência dessas comitivas régias de caça.

$\mathrm{Na}$ verdade, encontramos vários oficiais que superintendiam ao abastecimento dos géneros - dois homens da dispensaria, um da reposte e ainda o reposteiro do infante - e outros que tratariam das bebidas, os três homens de copa ${ }^{25}$. Mais especificamente, para responder ao fornecimento de pão cozido, que se quereria leve e fofo para os senhores, acompanhavam a comitiva a regueifeira do rei, com a manceba que a auxiliava, a do infante, e ainda se lhe acrescentava a manceba da regueifeira da rainha ${ }^{26}$, que serviria a sua senhora, já que D. Filipa por certo se juntaria ao seu marido e filho em muitas das refeições campestres de caça. Note-se que são mulheres as responsáveis pela confecção cuidada do pão ${ }^{27}$, que se demarcava como uma actividade essencialmente feminina ${ }^{28}$. Encontramos também um carniceiro, que por certo seria imprescindível para cortar a carne dos animais caçados, e ainda um iguador, que devia superintender

${ }^{20}$ Note-se que, no século XVI, o reposteiro evolui para uma função de guarda das tapeçarias, alcatifas e almofadas (Pereira 2011: 92). Por sua vez "periliteiro", palavra cujo significado desconhecemos, poderá levar-nos a pensar em peliteiros, que tivessem a seu cargo os resguardos e peles. $\mathrm{O}$ arauto e mestre do relógio recebiam, cada um, 1650 libras, o reposteiro 1200 e o "periliteiro" 1000.

${ }^{21}$ Também aqui é referido o comprador dos infantes, mas que depois se repete no apartado a eles respeitante.

${ }^{22} \mathrm{O}$ seu ordenado mensal era de 1200 libras, devendo por isso ser da cozinha privada do rei.

${ }^{23}$ Recebiam 800 libras.

${ }^{24}$ Destes havia 10 mais importantes, que recebiam uma ração de sete pães (equivalente a 900 libras) e 22 que recebiam uma ração de 4 pães (equivalente a 500 libras), o que dava um total mensal de 20000 libras. Cfr. Gomes 2011: 37.

${ }^{25}$ Cada um destes oficiais auferia 600 libras.

${ }^{26}$ As regueifeiras pagavam-se a 600 libras e metade as mancebas.

${ }^{27}$ Sabemos também que, a uma regueifeira do rei D. Fernando, Maria Vasques, o Mestre de Avis doara, enquanto fosse sua mercê, uma casa para morar, sem pagar aluguer, à porta de Mancos, em Santarém (CHDJ, vol. I, t. 2, doc. 655, de 5 de Setembro de 1384).

${ }^{28}$ Cfr. Coelho 1990a: 45-47. 


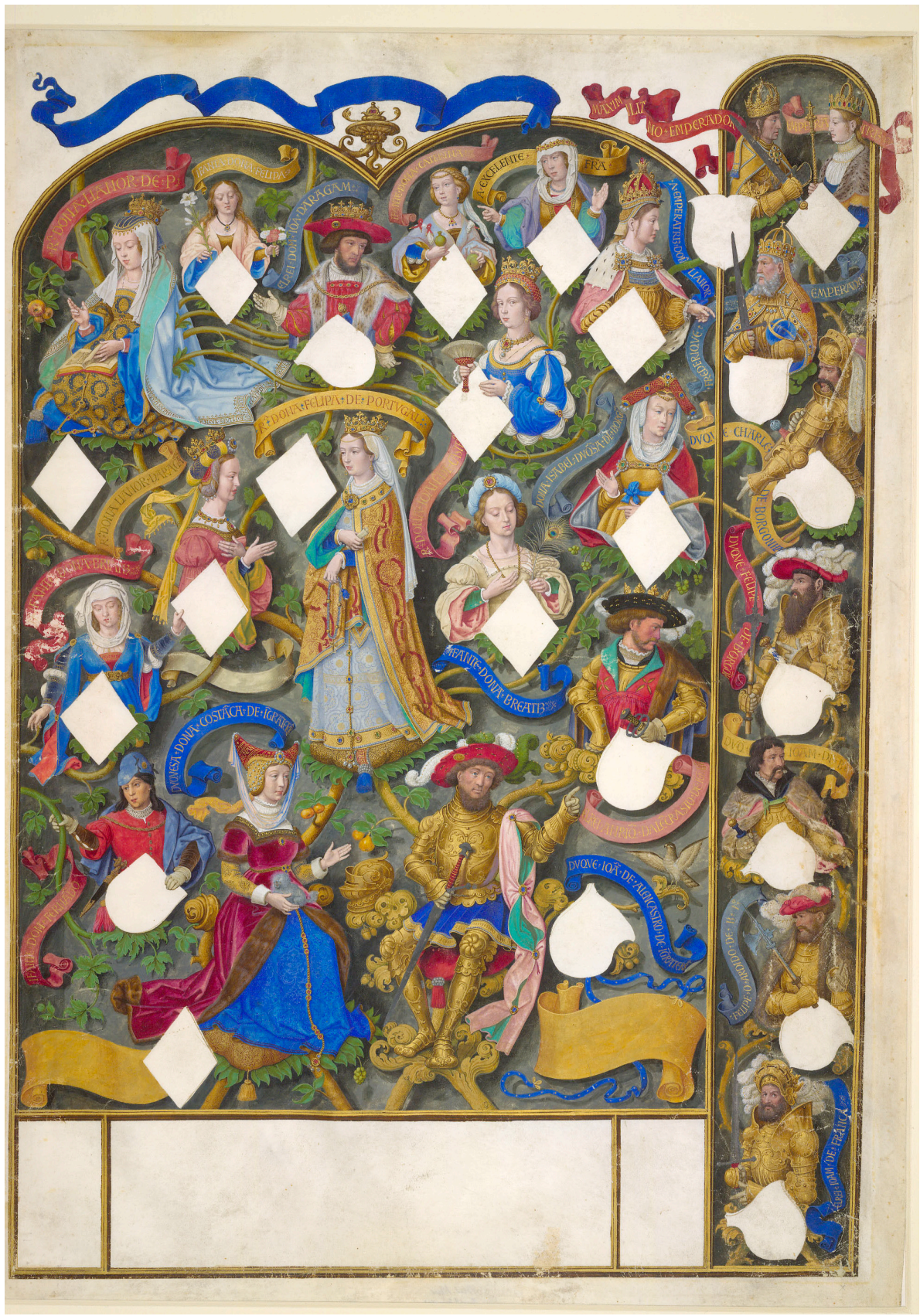

Fig. 3: D. Filipa de Lencastre (Genealogia dos Reis de Portugal de Simão Bening. British Library, Londres. Add. 12 53, no 10) 
na distribuição das rações alimentares dos muitos servidores da comitiva $^{29}$. Este vasto corpo de oficiais demonstra-nos, inequivocamente, a importância da arte venatória na corte avisina.

A lista de pessoal, que vimos seguindo, contempla ainda a casa da rainha, no seu séquito de donas, donzelas, vassalos e servidores. Era a casa da rainha o centro simbólico do gineceu, do núcleo feminino que compunha o universo social da corte. A casa da rainha tinha, pois, uma organização autónoma da do rei, com rendimentos e oficiais próprios. Essa autonomia garantia-lhe uma itinerância e vida separada da do monarca, ainda que as rainhas frequentassem, com mais ou menos regularidade, a corte régia ${ }^{30} . \mathrm{E}$ D. Filipa foi nela bastante assídua até porque com frequência participava nos negócios políticos e diplomáticos do reino ${ }^{31}$.

As funções de mesa e cozinha da rainha eram dirigidas, como já dissemos, pelo vedor, mas especificava-se ainda o copeiro, dois cozinheiros, um escrivão da cozinha ${ }^{32}$, uma regueifeira, um reposteiro e muitas mulheres, sem serviços especificados, que se repartiriam pelos trabalhos domésticos da câmara e da mesa $^{33}$. Atente-se que um dos cozinheiro era inglês, Richard, e outro português, Afonso Peres. Assim poderia D. Filipa dar resposta aos gostos culinários que trouxera da sua terra natal ou ainda surpreender os convivas da sua mesa com novidades de pratos e sabores ingleses, enquanto Afonso Peres responderia aos gostos culinários portugueses dos frequentadores da sua casa ${ }^{34}$.

Os infantes, que teriam nesta data, idades compreendidas entre os 11 anos - D. Duarte - e dois anos - D. João -, circulariam essencialmente entre a casa do rei e a da rainha. No entanto, já tinham alguns oficiais que estavam particularmente afectos à sua alimentação, como um $\operatorname{comprador}^{35}$, uma reguei-

${ }^{29}$ Recebiam, cada um, 500 libras.

${ }^{30}$ Sobre a itinerância das rainhas com os seus séquitos e funcionalidades, leia-se Rodrigues 2011: 44-63.

${ }^{31}$ As obras de Coelho 2011b e Silva 2012, entre os muitos aspectos da biografia desta rainha, abordam o seu protagonismo político.

${ }^{32}$ Justamente ao escrivão da cozinha da rainha, Vasco Afonso, concedeu D. João I, enquanto fosse sua mercê, a 12 de Outubro de 1390, umas casas em Lisboa, na Rua da Ferraria da judiaria (CHDJ, vol. II, t. 1, doc. 440).

${ }^{33} \mathrm{O}$ cozinheiro inglês, mais bem pago que o português, auferia 1000 libras e o segundo 800, mas superiorizava-se a ambos o escrivão da cozinha com 1700 libras. O copeiro recebia 1500 libras, a regueifeira 600 e o reposteiro 500 .

${ }^{34}$ Estas interferências e influências dos gostos nacionais ou regionais, que se detectam nos livros de cozinha, embora estes sejam mais exemplificativos de uma certa uniformização, de uma cozinha internacional ou de "uma espécie de gótico internacional em matéria de gosto alimentar”, são analisadas por Laurioux 2001: 78-82.

35 Comprador do infante D. Duarte fora Afonso Esteves, que, em 31 de Maio de 1413, recebeu de D. João I o emprazamento, em três vidas, de umas casas em Castelo de Vide, na Rua de Santa Maria (CHDJ, vol. III, t. 3, doc. 1048). Por sua vez o comprador-mor de D. Duarte, o escudeiro Pedro Anes, criado do conde D. Afonso, meio-irmão de D. Duarte, foi contemplado 
feira com a sua manceba, um cozinheiro, três reposteiros (dois de D. Duarte e um da infanta $\mathrm{D}$. Isabel), para além de vários moços de câmara ${ }^{36}$. Note-se que o cozinheiro aqui referido tem o mesmo nome do cozinheiro português de D. Filipa, o que nos leva a questionar se não seria o mesmo, o qual teria a seu cargo o especial provimento dos pequenos infantes na casa da rainha.

\section{Alimentos}

Conhecidos os homens e os espaços, acerquemo-nos da alimentação real. Mas, também aqui, haverá que ter em conta as múltiplas condicionantes da itinerância régia.

$\mathrm{Na}$ verdade, o Mestre de Avis e depois rei D. João I viveu em contextos de guerras e percursos rápidos de andada desde 1383 até aos finais do século XIV. Nessas circunstâncias estaria sujeito à comedoria que lhe ofereciam os hospedeiros e às contingências do abastecimento dos exércitos, por muito que, como chefe e rei, sempre usufruísse de um superior estatuto.

Durante o cerco de Lisboa, não terá por certo comido pão feito de bagaço de azeitona, de malvas ou de raízes de ervas ou esgaravatado o chão para colher grãos, nem recorrido à carne de bestas ${ }^{37}$. Mas terá provavelmente conhecido uma pior qualidade de géneros, quando o cereal, o vinho, o gado, as aves e os ovos escasseavam e os seus preços subiam, havendo talvez até recorrido à carne salgada que viera para $\mathrm{o}$ abastecimento da cidade ${ }^{38}$, e tendo suportado um racionamento de alimentos e de bebidas, desde logo de água. Basta recordar que Almada se rendeu aos castelhanos pela sede, tendo os seus moradores bebido água suja de lavar roupa ou salgada e comido pão amassado com vinho, que só se podia tragar quando estava quente, e em vinho tiveram de cozer a carne e o pescado ${ }^{39}$.

Surpreendemos poucas vezes o rei de Avis a tomar uma qualquer refeição em contextos militares. Na Páscoa de 1387, passada no arraial de Benavente de Campos, onde não havia muito gado nem alimentos, como nos refere a Crónica ${ }^{40}$, à noite D. João I pediu vinho e fruta e esteve em conversa com os seus homens ${ }^{41}$. Já no regresso da campanha anglo-lusa por terras de Castela, ainda que houvesse míngua de carnes, D. João não prescindiu de carne de

pelo infante com uma coutada a par de Santarém, doção que D. João I confirmou, a 8 de Março de 1421 (CHDJ, vol. IV, t. 1, doc. 290).

${ }^{36} \mathrm{O}$ comprador recebia 1000 libras, a regueifeira 600 e a sua manceba metade, enquanto os reposteiros parecem totalizar 4500 libras.

${ }^{37} C R D J$, cap. 148. Noutras contingências fez-se também pão de bolotas (CRDJ, I, cap. 100).

${ }^{38} C R D J$, I, cap. 115. A Santarém foram buscar gados, que depois salgaram em tinas.

${ }^{39}$ CRDJ, I, cap. 136.

${ }^{40}$ CRDJ, II, cap. 100.

${ }^{41}$ CRDJ, II, cap. 102. 
vaca, cozinhada de três maneiras distintas ${ }^{42}$. Mas, em algumas campanhas mais duras, poder-lhe-á ter acontecido o mesmo que a Nuno Álvares Pereira, quando em luta com os castelhanos por terras alentejanas, que durante um dia não teve mais para comer que um pão encetado, um pequeno rábano e um pouco de vinho, que um homem de pé levava numa cabacinha ${ }^{43}$.

Outros momentos de refeições ao ar livre, bem mais aprazíveis e deleitosos, ocorreriam durante as caçadas. Aí, como escreve D. João I no seu Livro de Montaria, "as iguarias (seriam) muitas, como cumpre de haverem os reis, que em tais lugares comerem; e outrossim que vinho que houverem de beber" ${ }^{44}$. Mas justamente o monarca aconselhava equilíbrio, por causa do esforço despendido e do calor do corpo, recomendando que os convivas comessem pouco e bebessem o vinho misturado com água, mais ainda que nos dias normais, ou seja, se estivessem habituados a bebê-lo terçado com água deviam então tomá-lo meado. Mas tais notas deixam-nos bem perceber que nesses momentos devia prevalecer o excesso, a que a euforia da caçada quase convidava, e não a regra ou os actos comedidos.

Será tempo, porém, de nos aproximarmos das refeições do rei nos seus paços, tomadas mais em privado, na câmara, no quotidiano dos dias, ou mais convivialmente, na sala, em dias extraordinários e comemorativos.

À mesa real chegavam as mais requintadas iguarias ao jantar ( refeição servida entre as 11 e 12 horas) e à ceia (servida entre as 6 e 7 horas) ${ }^{45}$. Em dias normais, poderiam degustar-se três pratos de carnes ao jantar e dois à ceia, além de outras vitualhas não contabilizadas, entre caça e marisco, como o determinava a pragmática de 1340 para os ricos-homens ${ }^{46}$, mas o seu número seria muito mais avultado nos banquetes festivos. Carne, caça, pescado, acompanhados de pão ${ }^{47}$ e vinho, e seguidos de frutas e doces não faltariam, demarcando-se a distinção real pela qualidade dos produtos e a sua requintada confecção ${ }^{48}$. No superior refinamento da mesa dos grandes, as melhores viandas não eram simplesmente cozidas, assadas, desfeitas, chacinadas ou fritas, mas manipulavam-se de muitas destas maneiras antes de se apresentarem em pratos, entre outros, de almôndegas, pastéis, tortas, empadas, doces, confeites ou conservas ${ }^{49}$.

${ }^{42}$ CRDJ, II, cap. 112.

${ }^{43}$ CRDJ, I, cap. 146.

${ }^{44}$ Livro da Montaria, cap. VII.

${ }^{45} \mathrm{O}$ jantar teria lugar entre as 10 e as 11 horas e a ceia ao cair da tarde, princípio da noite, segundo uns, ou entre as 11 e as 12 o primeiro e a ceia pelas 6 ou 7 horas da tarde, segundo outros, o que também dependeria dos períodos do ano. (Marques 2010: 28; Arnaut 1986: 56-59).

${ }^{46}$ Marques 1980: 109-110.

${ }^{47} \mathrm{Na}$ casa real entraram 2000 pães em 1424 (CHDD, vol. II, doc. 41).

${ }^{48}$ Genericamente, sobre a alimentação medieval, a um tempo um acto biológico, social e cultural, se reporta a obra de Laurioux 2002. Para um confronto da alimentação e da mesa dos diversos grupos sociais, veja-se a obra, largamente ilustrada, de Birlouez 2011.

${ }^{49}$ Leia-se Arnaut 1986: 104-111; Gonçalves 2010: 244-250. 
$\mathrm{Na}$ verdade, conhecemos uma preciosa carta de quitação de D. João I, passada em Lisboa, a 15 de Dezembro de 1430, e dirigida ao tesoureiro João Gonçalves, escudeiro que o serviu durante seis anos desde 1424, enumerando-se o que este recebera em panos, peles, armas, pratas, dinheiro, matérias-primas, objectos vários, géneros, especiarias, armas e livros, que nos deixa entrever um pouco o cenário da sua alimentação, gostos e mesa ${ }^{50}$.

Sabemos, desde logo, que D. João I, que por certo se alimentaria bem, não prescindia de carne de vaca cozida, assada e "desfeita" (picada ou em enchidos) ${ }^{51}$. Mas à corte, e por certo à sua mesa, chegaria também a carne de porco, de coelho e de aves, muito em especial a das apreciadas perdizes ${ }^{52}$. E gostaria de uma comida bem condimentada e com diferentes paladares. Entravam, por isso, nas cozinhas reais, grandes quantidades de especiarias e condimentos da terra ou importados. Refira-se, porém, que sobre os apetrechos da cozinha e o recheio das dispensas dos paços régios pouca informação colhemos, informando-nos apenas a referida quitação da existência de 410 tigelas, com múltiplas funções, 3 caldeiras, 50 seirões de esparto e 3 tonéis vazios ${ }^{53}$.

Mas tal fonte é bem mais esclarecedora quanto aos alimentos e afins ${ }^{54}$.

É-nos, então, dado a saber que, no ano de 1424 , o tesoureiro de D. João I recebeu cerca de 5 quilos e meio de pimenta e a mesma quantidade de gengibre branco, 2 quilos e 720 gramas de cravo da Índia e 6 quilos e 800 gramas de canela e cinamomo ${ }^{55}$. Nos anos seguintes de 1426 a 29 os valores perfizeram 11 quilos de pimenta, 5 quilos e meio de gengibre, 467 quilos e 440 gramas de açafrão e 11 quilos de canela e cinamomo ${ }^{56}$. Nas refeições reais os sabores fortes e picantes prevaleceriam, ainda que aromatizados com certas ervas, e os manjares desprenderiam cheiros intensos e convidativos ao prazer da degustação ${ }^{57}$.

${ }^{50}$ CHDD, vol. II, doc. 41.

${ }^{51}$ CRDJ, II, cap. 112.

${ }^{52}$ HFAC, vol. I, doc. 341, de 8 de Fevereiro de 1427, carta de quitação ao comprador do rei, Afonso Anes, que se reporta ao que ele despendera em 12 anos passados. Ficara, no entanto, devedor de certo abastecimento em peixe e carne, que se discrimina, dívida que lhe era perdoada. Em tal carta enumeravam-se 9 cobros (porções) de cachaço, 4 lacões (presuntos) e 224 assadas de porco (lombo de porco para assar), além de 157 coelhos, 110 concarez (parece ser uma ave, mas que não identificámos), 152 pombos e 10 perdizes.

${ }^{53}$ CHDD, vol. II, doc. 41. Sobre o equipamento de várias cozinhas senhoriais portuguesas e o respectivo pessoal de cozinha consulte-se Arnaut 1986: 47-55; Gonçalves 2010: 239-244. E para um contexto europeu do recheio de cozinhas de diversos estratos sociais leia-se Piponnier 2001: 123-129.

${ }^{54}$ Para um confronto com um livro de contas de cozinha do século XVI, que nos relata o abastecimento alimentar na corte de D. João III, veja-se a obra de Santos 2002. Os alimentos da mesa real em Quinhentos são igualmente particularizados por Buescu 2011: 304-317.

${ }^{55}$ Cinamomo era, também, um certo tipo de canela.

${ }^{56}$ CHDD, vol. II, doc. 41.

${ }^{57}$ Sobre o consumo das especiarias, as preferências de gostos, oscilando entre o forte, o doce e o ácido, e o apelativo visual das cores dos pratos, veja-se Laurioux 2001: 71-74, 77-78. Por sua vez Flandrin 2001: 95-110 analisa o uso das especiarias e condimentos na culinária, não apenas 
O rei de Avis seria, igualmente, bom apreciador de peixe. À casa real, como nos dá conta uma outra carta de quitação passada ao comprador do rei, Afonso Anes, chegava uma enormíssima variedade de pescado, fresco ou seco, entre lampreias, arenques, congros, cações, galhudas (também uma espécie de cação), salmonetes, linguados, azevias, pescadas, besugos, choupas (sargos), bogas, cachuchos, mugens, bodalos, fanecas, tainhas, rodovalhos, solhos, samas, gorazes, alitães (espécie de peixe seco, proveniente de pequenos tubarões que se pescavam no Algarve), moreias, evos (certa espécie de peixe), sardinhas, enguias, além de crustáceos, bivalves e moluscos, como lagostas, ostras, sibas (chocos) e lulas $5^{58}$, o que bem demonstra o apreço por este alimento, mais leve e puro que a carne, mesmo algo sacralizado $^{59}$, que obrigatoriamente se servia em dias de abstinência e jejum ${ }^{60}$.

Por sua vez a quitação passada ao tesoureiro João Gonçalves refere-nos que, nos anos de 1426 a 29, entraram nas cozinhas reais 11322 pescadas secas e 120 peças de alitães ${ }^{61}$. Além disso, D. João I, querendo ter o privilégio de degustar trutas quando itinerava pela comarca da Beira, instituiu mesmo uma coutada régia no Zêzere, no pego de Mourão, cerca de Belmonte ${ }^{62}$.

Por contraponto ao seu marido, D. Filipa comia "não por deleitação somente por suster a vida. Nem o seu cozinheiro não era muito constrangido para buscar novas maneiras de iguarias", como afirma Zurara na Crónica da Tomada de Ceuta ${ }^{63}$.

Cumpririam o rei e a rainha os jejuns e abstinências nos dias determinados pela Igreja, privando-se de carne e alimentos. D. Filipa “jejuava tanto como a sua natureza podia sofrer", tendo até o físico de a obrigar a comer, como refere Zurara ${ }^{64}$.

No que toca aos vinhos, seriam os melhores que chegariam à corte, ainda que de diversas qualidades, até para contemplar os diferentes gostos e exigências de acordo com os pratos. No ano de 1424 entraram na escançaria

em relação com os sabores, mas também com a dietética

${ }^{58} \mathrm{HFAC}$, vol.I, doc. 341 . Vejamos os quantitativos que a fonte refere - 28 lampreias, 63 arenques, 206 congros secos, 28 congros frescos, 5 cangrias (será feminino de congro?), 3 empadas de congro, 23 cações, 26 cações secos, 54 galhudas (mais à frente enumera outra vez 54 galhudas, o que parece ser uma repetição), 586 salmonetes, 300 linguados, 222 azevias, 2740 pescadas secas, 1687 besugos, 160 choupas douradas, 212 bogas, 251 cachuchos, 1181 mugens, 1414 bodalos, 51 fanecas, 72 tainhas, 4 rodovalhos, 12 postas de solho, 102 samas, 269 gorazes, 271 alitães, 3 moreias, 20 postas de evo, 40000 sardinhas, 5 enguias, 22 lagostas, 136 ostras, 12 sibas, 70 lulas (este valor surge arrolado por duas vezes, certamente uma repetição). Será de destacar os milhares de sardinhas, que, sendo baratas, alimentariam certamente a domesticidade, e, logo depois, ultrapassando os milhares de espécies, e por ordem decrescente, as pescadas secas, os besugos, os bodalos e os mugens.

${ }^{59}$ Coelho 1995: 100-101.

${ }^{60} \mathrm{O}$ consumo do pescado - mas também da fruta - na corte de D. Afonso V foi estudado por Santos 1997: 1-33.

${ }^{61}$ CHDD, vol. II, doc. 41.

${ }^{62}$ CHDJ, vol. II, t. 3, doc.1502, de 16 de Março de 1403.

${ }^{63}$ CRTC, cap. XLVI.

${ }^{64}$ CRTC, cap. XLVII. As refeições "gordas" e "magras" da mesa régia em itinerância foram estudadas por Gonçalves 2011: 286-303. 
régia avisina 8100 litros de vinhos e, nos anos de 1426 a 29,26 100 litros de vinhos da terra, 3600 litros de tintos e mais de 12 piparotes de malvasia ${ }^{65}$, sendo estes dos melhores vinhos doces e perfumados.

Mas a família de Avis parece ter sido moderada no beber ${ }^{66}$. Como vimos, pelos menos durante as caçadas, D. João I recomendava que se bebesse vinho combinado com água, como certamente ele o faria. D. Duarte, por sua vez, bebia o vinho misturado com duas partes de água, D. Henrique não terá bebido durante a maior parte da sua vida e também parece ter sido abstémio o infante D. Fernando. De facto, na corte avisina, não se afigurava ser elogiosa a fama de ser um grande bebedor ${ }^{67}$.

Todavia, uma refeição muito habitual e leve, que podia ocorrer a qualquer hora do dia ou da noite, era constituída, como se dizia, por vinho e fruta, que se compunha desses elementos mas também de doces e confeitos. Eram estes confeitos pequenas sementes ou frutos que se cobriam de açúcar.

Assim, o tesoureiro da casa real adquiriu 10 quilos e 880 gramas de confeitos em 1424, enquanto nos anos seguintes entrou um piparote deles. O precioso açúcar marcava já uma presença significativa na corte joanina. Em 1424 refere-se uma quantidade de 14 quilos e 450 gramas e para os anos de 1426 a 29 alude-se a 88 quilos de açúcar em pão ${ }^{68}$, certamente em forma, onde fora depositada a calda fervida do açúcar, e ainda 44 quilos de açúcar de panela, portanto caramelizado.

De onde proviria? Como hipótese, atendendo aos altos valores e ao modo como se apresentava, perguntamo-nos se poderia vir do Algarve. $\mathrm{Na}$ verdade, em 1404, D. João I coutara ao mercador genovês João de Palma um terreno em Quarteira, onde ele tinha uma plantação de cana de açúcar ${ }^{69}$ e daí poderia chegar esse adoçante, embora não sejam de excluir outras possíveis proveniências ${ }^{70}$. E com ele se fariam depois os confeites e as conservas.

Entre 1426 e 29, havia na casa real 5 açucareiros de gengibre confeite e outros tantos de marmelos confeitos. Mas muitos mais confeitos se poderiam confeccionar, dado que entraram na dispensa régia 44 quilos de amêndoas descascadas, em 1424, e 506 quilos nos outros quatro anos. E para as refeições leves de fruta e vinho, como para a sobremesa, a casa do rei adquiriu também nesses anos 300

${ }^{65}$ CHDD, vol. II, doc. 41.

${ }^{66} \mathrm{Um}$ estudo da circulação dos vinhos e seus consumos se apresenta no trabalho de Coelho 2005a: 112-121.

${ }^{67}$ Arnaut 1986: 39-40. Sobre a necessidade das bebidas do homem medieval, mas muito em particular sobre o prazer e sociabilidade em torno do vinho, leia-se Verdon 2002.

${ }^{68}$ Designava-se açúcar em pão a calda da cana de açúcar fervida e apurada, que era colocada numa forma de barro cónica para transporte, que era denominada pão de açúcar.

${ }^{69} \mathrm{CHDJ}$, vol. II, t. 3 , doc. 1577.

${ }^{70}$ Digamos que seria também possível vir da Sicília, de Granada ou Valência e ainda de Ceuta. Não nos parece poder ter vindo da Madeira, dado que a primeira referência ao açúcar da Madeira data de 1433 (Cfr. Nunes 2003: 9-10). 
romãs e 44 quilos e 660 gramas de tâmaras ${ }^{71}$, fruto que a presença portuguesa em Marrocos podia já garantir com esta forte expressão de consumo na mesa do rei.

\section{BANQuetes}

As refeições alargadas teriam lugar por ocasião das festas religiosas - desde logo Natal, Epifania, Páscoa e Pentecostes e em dias de alguns santos ${ }^{72}$ - mas também sempre que o monarca desejava receber embaixadores e convidados ilustres ou comemorar eventos especiais, muito em particular as alianças de casamento.

Os banquetes reais, manifestações de poder, propaganda e espectáculo, revestiam-se de uma etiqueta e cerimonial rigorosos ${ }^{73}$. Todo o ritual se desenvolvia em torno da figura central do rei, colocado ao meio da mesa principal e mais elevada, se várias existissem, codificando-se a partir dele, e por honra dos lugares a si mais chegados, a disposição dos convivas, segundo o seu estatuto social e respeitando a mais rigorosa hierarquia ${ }^{74}$.

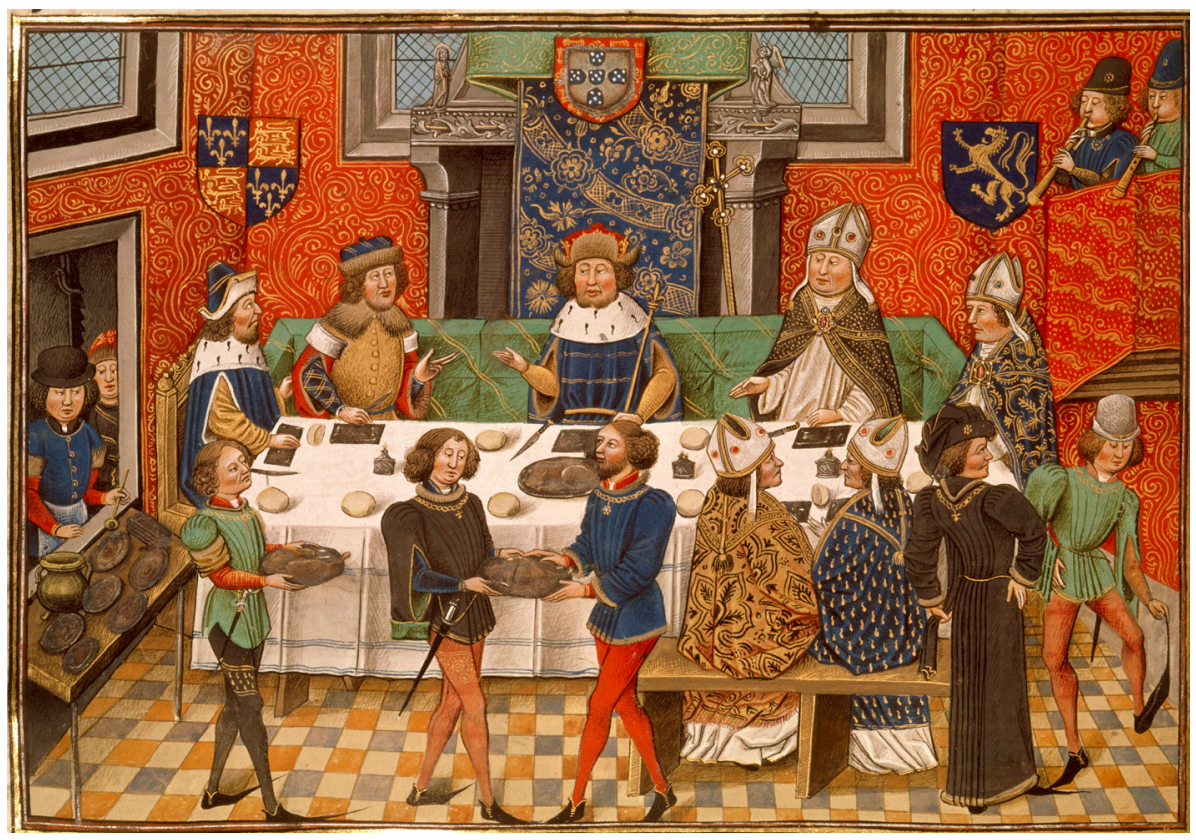

Fig. 4: Representação do jantar de D. João I com João de Gand em Ponte de Mouros. (Chronique d'Alngleterre de Jean Wavrin. British Libray. Roy.14.E.IV, f. 244v).

${ }^{71}$ CHDD, vol. II, doc. 41.

${ }^{72}$ Um sentido socialmente alargado do convívio festivo nestas festas litúrgicas e noutros momentos da vida e trabalho dos homens se pode colher no estudo de Coelho 2010: 144-169.

${ }^{73}$ Strong 2004 estuda os banquetes segundo diversas perspectivas de análise.

${ }^{74}$ A estratégia política da mesa é tratada por Miranda 2011: 382-405. 
A sala estaria cerimoniosamente ornamentada com tapeçarias, reproduzindo as armas reais e outra armaria, ou cenas de caça, de guerra ou afins, e com ostentação se exibia a rica baixela de ouro e prata, que se utilizava ${ }^{75}$.

É do nosso conhecimento que o rei de Avis possuía, pelo menos, dezanove taças de prata de bastiães, portanto ornamentadas com lavores em relevo, que pesavam cerca de $7 \mathrm{Kg}$, três copas com suas sobrecopas, logo tapadas, com mais de $3,5 \mathrm{~kg}$ e dois agomis de $\operatorname{prata}^{76}$. Das copas jorraria o vinho que enchia as taças dos comensais, enquanto os agomis serviam para dar água às mãos. Mas dispunha também de uma rara baixela de vidro, que viera de Ceuta, no Inverno, e que o seu armeiro guardara para só a apresentar ao monarca no Verão, quando seria agradavelmente fresca para o serviço da mesa ${ }^{77}$.

Para compor a ambiência da sala, dando-lhe aparato, conforto e beleza, dispunha a casa real de reposteiros de pano de Gales, que se utilizavam muitas vezes para dissimular as portas, e ainda de panos de armar, peças móveis, fossem tapeçarias para decorar, panos para cobrir as paredes, emprestando-lhes calor no Inverno, ou cortinados para compartimentar um salão ${ }^{78}$. Acrescentavam-se 11 bancais com figuras, certamente de animais ou pessoas, e 9 com rótulos, talvez com títulos e divisas, portanto tecidos almofadados com que se cobriam as mesas e os bancos, oferecendo maior comodidade nos repastos. Depois de resguardadas com os bancais, as mesas eram cobertas com toalhas, possuindo D. João I toalhas francesas, que envolviam mais de $200 \mathrm{~m}$ de tecido. Para além disso a quantidade de panos adquiridos pela casa real entre 1425 e 1429, importados de Inglaterra, Irlanda, Escócia, País de Gales, Países Baixos, França e Península Ibérica, entre escarlatas, cetins, brocados e muito outros, poderiam evocar-nos o luxo e aparato da corte, que se ostentaria muito em particular na sala e na mesa.

À mesa respeitavam-se as éticas e etiquetas no modo de chegar os alimentos à boca, apenas com três dedos, e de manter as hierarquias, a compostura e as boas maneiras durante a refeição ${ }^{79}$. Luz, música, dança, entretenimentos deviam dar brilho e alegria ao convívio em torno da mesa. Sendo ainda comum, nesse espaço e momento, sublinhar a habitual familiaridade com os animais,

${ }^{75}$ Cfr. Arnaut 1986: 60-73; Piponnier 2001: 129-132. Para tempos modernos, os espaços e baixela da mesa dos reis são estudados por vários autores na obra A Mesa dos Reis de Portugal: 116-165.

${ }^{76}$ CHDD, vol. II, doc. 41.

${ }^{77}$ Livro da Virtuosa Benfeitoria, livro segundo, cap. XXIX.

${ }_{78}$ Marques 2010: 111.

${ }^{79}$ Arnaut 1986: 73-87 ; Gonçalves 2010: 256-259. O cerimonial e a etiqueta das mesas reais entre a medievalidade e a modernidade são abordados por diversos especialistas na obra $A$ Mesa dos Reis de Portugal: 188-259. Romagnoli, 2001: 111-121, estuda o processo civilizacional dos bons comportamentos e das regras de mesa e Alexandre-Bidon 2001:137-139 aborda também as normas de civilidade. 
por todos os cães, que, disseminados pela sala, iam sendo mimoseados com alguns sobejos de comida pelos convivas.

Nos inícios do reinado de D. João I não teríamos ainda o espectáculo e a ritualidade acabados do banquete polarizado em torno de um rei absoluto. Mas o respeito e a adequada distribuição das hierarquias sociais, as regras de bem acolher e servir, a demarcação do rei e da corte, segundo cânones prefixados, fariam parte da cultura cortesã avisina, que foi, por isso, evoluindo de acordo com as modas coevas e os contactos com estrangeiros, mormente os ingleses, cujos costumes mais se terão divulgado e imposto com a rainha D. Filipa.

$\mathrm{E}$ mesmo nos momentos menos favoráveis eles tinham lugar. Assim, quando em 1386, D. João se encontrou, pela primeira vez, com o duque de Lencastre em Ponte de Mouro, numa tenda, aí "asentaram-se a comer ambos dhuuma parte, sem curamdo da parte dereita nem esquerda, ca ajmda nom era entom em vsso" 80 .

Estas liberdades de assento à mesa, se não houvesse a correcta noção das hierarquias, podiam causar graves problemas. Lembremos que, por ocasião do banquete de bodas de casamento oferecido por D. Juan I de Castela e D. Beatriz, em Badajoz, aos mais altos fidalgos portugueses e castelhanos, Nuno Álvares Pereira, vendo quebradas as precedências nobiliárquicas, e não tendo sido guardados, para si e para seu irmão Fernão Pereira, os lugares que a honra da sua linhagem exigia, derrubou violentamente a mesa, onde lhes competia sentarem-se, e abandonou, muito irado, o convívio ${ }^{81}$.

Mas se a moda da distribuição, seguindo a direita e a esquerda da figura principal, não era ainda corrente na década de 80 na corte de Avis, outras regras de etiqueta já existiam. Assim, logo no ano seguinte, estando D. João I com o mesmo duque, instalados em tendas nas terras de Guimarães, o monarca convidou para um banquete os ingleses, galegos e castelhanos que estavam na companhia do duque "e fez-lhes huuma muy real salla naquela tenda hu forom os conselhos e em outras que armaram junto todas ao lomgo huuma ante outra". Foi vedor da cerimónia Nuno Álvares Pereira "asseentamdo cada huum segumdo seu estado aas mesas hu aujam de comer”. E porque de nobres estrangeiros se tratava, como deferência máxima, "gramdes fidalgos (claro que portugueses) seruiam de toalha e copa e das outras cousas a tal convite pertençentes" ${ }^{82}$.

Ainda que em situações fora do comum, pois estávamos em acampamentos de cercos, torna-se claro que não se prescindia de montar uma arquitectura efémera de salas em tendas, de respeitar uma etiqueta de distribuição dos convivas pela mesa, segundo as suas dignidades, da mesma forma que se

\footnotetext{
${ }^{80}$ CRDJ, II, cap. XCII.

${ }^{81} C R D F$, cap. CLXVI.

${ }^{82}$ CRDJ, II, cap. XCIV.
} 
punha em prática um uso talvez bem português e da corte avisina, o de, em especiais momentos, sempre os grandes servirem as mais elevadas hierarquias, chegando-lhes a toalha e água para as mãos.

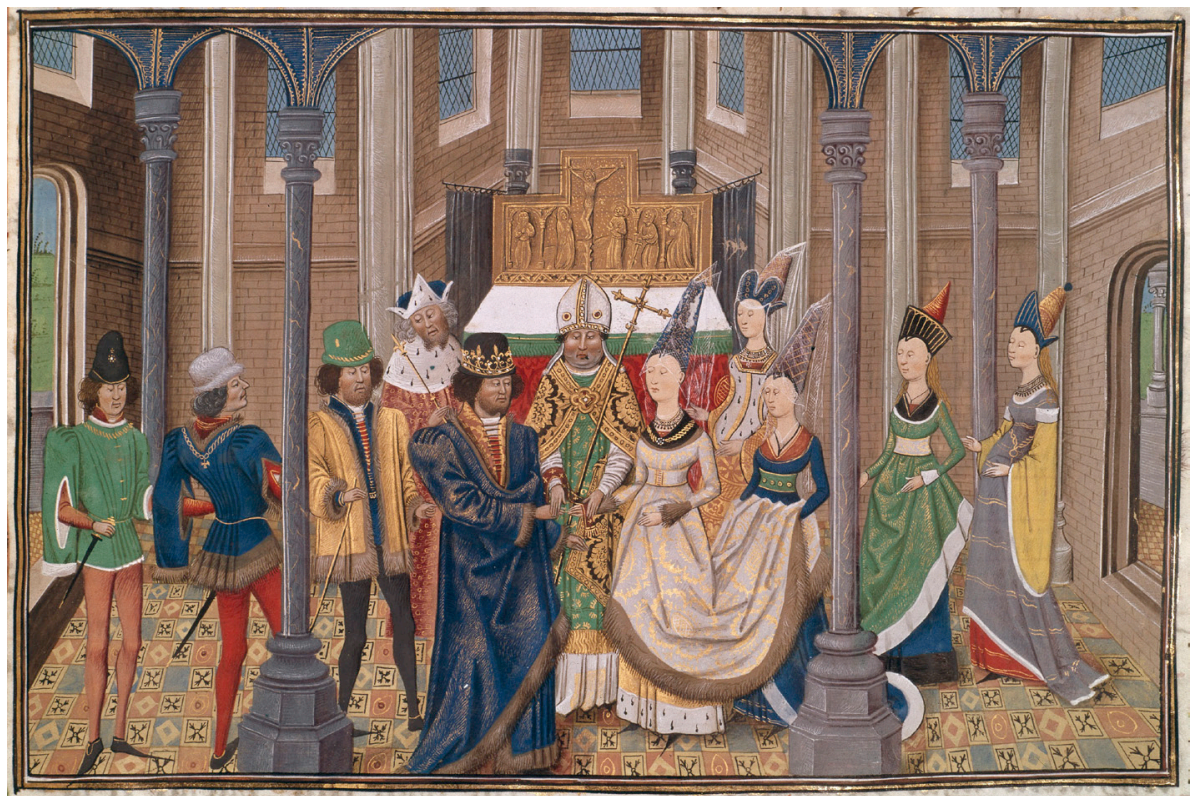

Fig. 5: Representação do casamento de D. João I com D. Filipa de Lencastre (Chronique d'Alngleterre de Jean Wavrin. British Libray. Londres).

E, finalmente, evoquemos as bodas reais do casal de Avis, descritas por Fernão Lopes:

"as mesas estauom ja muyto guarnidas de todo o que lhe compria, nom soomente homde os noiuos auyam destar, mas aquellas hu era hordenado de comerem bispos e outras homradas pessoas de fidalgos e burgueses do logar e donas e domzellas do paaço e da çidade.

O mestresalla da uoda era Nunaluarez Pereira, Comdestabre de Portugall. Seruidores de toalha e copa e doutros offiçios eram gramdes fidalgos e caualleiros, homde ouue assaz de jguarias de desuairadas maneiras de manjares. Em quanto o espaço do comer durou, faziam jogos a vista de todos homeens que o bem sabyam fazer, assy como trepar em cordas e tornos de mesas e salto reall e outras cousas de sabor; as quaaes acabadas, alçarom-sse todos e começarom a damçar, e as donas em seu bamdo cantando arredor com gramde prazer" ${ }^{33}$.

\footnotetext{
${ }^{83}$ CRDJ, II, cap. XCVI.
} 
Tradição e modernidade convergiram nesse banquete. As mesas estavam aprontadas com os seus compridos mantéis e boa baixela. A comida foi em abundância, variada e confeccionada de diversas maneiras. Como era costume, a cerimónia foi dirigida pela mais alta figura do reino, o Condestável, e, uma vez mais, o serviço à mesa, de toalha e copa, coube a grandes fidalgos e cavaleiros.

Havia várias mesas, pressupondo-se que o casal real ocuparia a principal, para ser admirado e venerado por todos. Nas demais distribuíam-se os convidados, em lugares ordenados. Mas, numa novidade muito consentânea com estes tempos primevos da realeza joanina, nelas se sentavam bispos, fidalgos, burgueses, homens e mulheres, numa grande abertura aos diversos estratos sociais e ao convívio de ambos os sexos. Talvez nunca antes vistos teriam sido os malabarismos proporcionados durante a refeição, entre saltos e acrobacias. E terminado o festim, foi ainda em alegre partilha que dançaram homens e mulheres, ao som do mavioso cantar de vozes femininas.

Anunciava-se o extraordinário festivo da futura corte avisina. E a dimensão cerimonial da vida da corte ter-se-á ampliado com a presença dos arautos e oficiais de armas, codificando as hierarquias sociais, do mestre sala, do trinchante, do trombeteiro e do corpo de músicos e jograis ${ }^{84}$, que acompanhavam a realeza. Acrescentada ainda com o rigor do tempo marcado por um relógio mecânico, por certo de origem inglesa ${ }^{85}$, já que parece ser dessa nacionalidade o "mestre do rrelogio", Colim, que se conhece para $1402^{86}$.

E teremos de concluir.

A mesa do rei caracterizava-se pela abundância, pelas "muitas iguarias", como afirma D. João I no Livro de Montaria. A mesa do rei de Avis distinguia-se pela melhor e maior quantidade dos alimentos, pela sua requintada confecção e cuidada apresentação, e pela etiqueta do serviço. E em tempos joaninos ela teria sido ainda um espaço material e concreto, mas também ritual e simbólico, da miscigenação cultural entre costumes, modas e gostos ingleses e portugueses.

$\mathrm{Na}$ cultura de aparato da corte, a festa irrompia com frequência nos paços do rei, da rainha e dos infantes. Ou mesmo em espaços mais amplos de ar livre, como as frequentes caçadas. E com ela a mesa mais se abrilhantava em víveres, em criadagem, em baixela, em cerimónias, em cortesias.

${ }^{84}$ Seis jograis e um arauto se contam na lista da casa real em 1402, como vimos ( $M H$, I, doc. 122,), enquanto servia D. Filipa o judeu Judas Negro, "grande trovador, segundo as trovas daquele tempo" (CRTC, cap. XXX).

${ }^{85}$ Segundo a tradição, o duque de Lencastre oferecera a D. João I um relógio mecânico (Marques 2010: 68).

${ }^{86} \mathrm{MH}, \mathrm{I}, \mathrm{doc} .122$. 
Mas, mesmo no comum “pão de cada dia”, a mesa real sobressaía face à dos demais membros da sociedade, mormente face à dos não privilegiados. Porque, ontem como hoje, a mesa é bem o consumado paradigma das hierarquias sociais e a realeza ocupava, em qualquer tempo ou espaço, o topo da pirâmide social. 


\section{Bibliografia}

\section{FonTES}

[CHDD], Chancelarias Portuguesas. D. Duarte, org. João José Alves Dias (1999), vol. II, Lisboa, Centro de Estudos Históricos - Universidade Nova de Lisboa.

[CHDJ] Chancelarias Portuguesas. D. João I, org. João José Alves Dias (2004-2006), 4 vols., Lisboa, Centro de Estudos Históricos - Universidade Nova de Lisboa.

[Livro de Montaria] Livro da Montaria feito por el-Rei D. João I de Portugal, introd., leitura e notas de Manuela Mendonça (2003), Ericeira, Mar das Letras-Editora.

[HFAC] História Florestal, Aquicola e Cinegética. Colectânea de Documentos Existentes no Arquivo Nacional da Torre do Tombo. Chancelarias Reais, dir. C. M. L. Baeta Neves (1980), vol. I, (1208-1438), Lisboa, Ministério da Agricultura e Pesca; DirecçãoGeral do Ordenamento e Gestão Florestal.

[MH] Monumenta Henricina, ed. da Comissão Executiva das Comemorações do V Centenário da Morte do Infante D. Henrique (1960), vol. I, Coimbra, Atlântida.

"Livro de Cozinha" da Infanta D. Maria de Portugal, ed. S. D. Arnaut e G. Manupella (1967), Lisboa, Imprensa Nacional-Casa da Moeda.

Afonso X, o Sábio (Rei de Castela), Las Siete Partidas del Rey Don Alfonso El Sabio, cotejadas con varios codices antiguos por la Real Academia de la Historia (1807), 3 T., Madrid, Imprenta Real.

Anchieta, José de (1554-1594), Cartas: informações, fragmentos históricos e sermões do Padre Joseph de Anchieta (1933), III, Cartas Jesuíticas, Rio de Janeiro, Civilização Brasileira.

Apiano, Roman History. Transl. Horace White (1958). London, William Heinemann, 4 v. (The Loeb Classical Library).

Apício, O Livro de Cozinha de Apicio. Um breviário do gosto imperial romano. Trad. Inês de Ornellas e Castro (1997). Sintra, Colares.

Arte Nova e Curiosa para Conserveiros, Confeiteiros e Copeiros (1788),, estudo e actualização de Isabel Drumond Braga (2004), Sintra, Colares Editora.

Bluteau, Rafael (1712-1728), Vocabulario Portuguez E Latino. Coimbra, Colégio das Artes da Companhia de Jesus.

Brandão, João (1552), Grandeza e abastança de Lisboa em 1552, org. e notas de José da Felicidade Alves (1999), Livros Horizonte, Lisboa.

Cartas do Padre António Vieira, ed. por J. L D’Azevedo (1925), Coimbra, Imprensa da Universidade.

César, Júlio, Guerra de África, trad. A. Bouvet (1949), Guerre d'Afrique, Paris, Les Belles Lettres.

Cunha, Luís (1647-1651), Cartas, introd. e transc.J.C. G Serafim (2011), Um Diálogo Epistolar. D. Vicente Nogueira e o Marquês de Niza, Porto, CITCEM e Edições Afrontamento.

Dessau, Hermann (1963). Inscriptiones Latinae Selectae (ILS). Berlin, Weidmannos, $3 \mathrm{v}$. Gandavo, Pero de Magalhães (1566), Tratado descritivo do Brasil. 
Le Pontique, Évagre, Traité Pratique ou le Moine, 2 vols, A. Guillaumont e C. Guillaumont ed. e trad. (1971), SC 170-171.

Góis, Damião de, Crónica do Felicíssimo Rei D. Manuel, nova edição (1955), Coimbra, Por ordem da Universidade, Parte IV.

Guevara, A. de (1539), Menosprecio de Corte y Alabanza de Aldea, ed. de Asunción Rallo Gruss (1984), Madrid, Ediciones Cátedra.

História Augusta, Les empereurs romains des $I I^{e}$ et III siècles. Trad. André Chastagnol (1994). Paris, Robert Laffont. (Collection Bouquins)

Homero, Odisseia. Lourenço, F. (2005, 6 ${ }^{\mathrm{a}}$ ed.) Lisboa, Livros Cotovia.

Horácio, Satires. Trad. François Villeneuve (1932). Paris, Les Belles Lettres. (Collection des Universités de France)

Infante D. Pedro, [Livro da Virtuosa Benfeitoria] O Livro da Virtuosa Benfeitoria, introd. e revisão Manuel Lopes Almeida (1981), Obras dos Príncipes de Avis, Porto, Lello \& Irmão-Editores.

Magnus, Gregorius, Moralia in Job, M. Adriaen ed. (2005), CCEL SL 140 A-B, 2 vols, Brepols.

César, Júlio, Guerre d'Afrique. Trad. A. Bouvet (1949). Paris, Les Belles Lettres. (Collections des Universités de France)

Juvenal, Satires. Trad. Pierre de Labriolle et François Villeneuve (1921). Paris, Les Belles Lettres. (Collection des Universités de France)

Lavanha, João Baptista (1622), Viagem da Catholica Real Magestade del Rey D. Filipe II N.S. ao Reyno de Portvgal e rellaçao do solene recebimento que nelle se lhe fez $S$. Magestade a mandou escrever, Madrid.

Lima, C. de L. (1887), Cozinheiro Imperial ou Nova Arte do Cozinheiro e do Copeiro. Por R. C. M. Chefe de Cozinha. Eduardo \& Henrique Laemmert. Rio de Janeiro, 10a edição.

Livro de superintendência da cozinha do Real Colégio de S. Pedro de Coimbra, (1687|88)

Livro dos Conselhos, ed. diplom. e trans. J. J. A. Dias, introd. MARQUES (1982), Livro dos Conselhos de El-Rei D. Duarte (Livro da Cartuxa), Lisboa, Editorial Estampa.

Lopes, Fernão, [CRDJ] Crónica del rei Dom João I de Boa Memória, Parte Primeira (1977), Lisboa, Imprensa Nacional-Casa da Moeda.

Lopes, Fernão, [CRDF] Crónica de D. Fernando, ed. crítica, introdução e índices Guliano Macchi (2004, 2a ed.), Lisboa, Imprensa Nacional - Casa da Moeda.

Lusitano, Amato, Centúrias de Curas Medicinais, pref. e trad. Firmino Crespo (1983), Lisboa, Universidade Nova de Lisboa - Faculdade de Ciências Médicas.

Monçon, Francisco de (1544), Libro Primero del Espejo del Principe Christiano, que trata como se ha de criar un Principe o niños generosos des de su tierna niñez có todos los Exercicios Eं virtudes que le convienen hasta ser varon perfecto. Contiene muy singulares doctrinas morales y apazibles, Lisboa, Luís Rodrigues.

Nogueira, Vicente (1647-1651), Cartas, introd. e transc.por J. C. G Serafim (2011), Um Diálogo Epistolar. D. Vicente Nogueira e o Marquês de Niza, Porto, CITCEM e Edições Afrontamento

Oliveira, Francisco Nicolau de, (1620) Livro das Grandezas de Lisboa (1804), Lisboa. 
Caminha, Pero Vaz de, (1500) Carta a el-Rei D. Manuel sobre o achamento do Brasil. Magalhães, J. R. e Salvado, J. P. (coords.) (2000), A Carta de Pêro Vaz de Caminha, Leitura paleográfica de E. Borges Nunes. Actualização ortográfica e notas de M. Viegas Guerreiro. Comissão Nacional para as Comemorações dos Descobrimentos Portugueses - Imprensa Nacional-Casa da Moeda, Lisboa.

Petrônio, Le Satiricon. Trad. Alfred Ernout (1955). 3. ed. Paris, Les Belles Lettres. (Collection des Universités de France)

Piccolomini, Aeneas Silvio (1563), Tractado de la Miseria de los Cortesanos, que escrivio el Papa Pio, ante que fuesse Summo Pontifice, a un cavallero amigo suyo Coimbra, João de Barreira.

Pseudo-Aristóteles Segredo dos Segredos, Introdução e notas de Artur Moreira de Sá (1960), tradução portuguesa, segundo um manuscrito inédito do séc. XV, Faculdade de Letras da Universidade de Lisboa, Lisboa,.

Receitas e Despesas da Fazenda Real (1384 a 1481), Faro, Jorge (1965), Receitas e Despesas da Fazenda Real de 1384 a 1481 (Subsídios Documentais), Lisboa, Fundação do Centro de Estudos Económicos.

Relatório do Marquês do Lavradio vice-rei do Brasil (1842), Revista do Instituto Histórico e Geográfico Brasileiro, 4: 409-486.

Relatório do vice-rei do Estado do Brasil Luís de Vasconcelos ao entregar o governo ao seu sucessor o conde de Resende (1860), Revista do Instituto Histórico e Geográfico Brasileiro, 23: 143-239.

Rigaud, Lucas (1860), Cozinheiro Moderno ou Nova Arte de Cozinha, prefácio de Alfredo Saramago (1999) Colares Editora, Sintra.

Rodrigues, Domingos (1682), Arte de Cozinha, apresentação, notas e glossário Maria da Graça Pericão e Maria Isabel Faria (1987), Lisboa, Imprensa Nacional-Casa da Moeda

Sousa, Gabriel Soares de (1587), Tratado Descritivo do Brasil em 1587, (1971), São Paulo, Cia. Editora Nacional.

Vitrúvio, Tratado de Arquitetura. Trad. M. Justino Maciel (2006),. Lisboa: IST Press.

Zurara, Gomes Eanes de (1415), [CRTC] Crónica da Tomada de Ceuta por el-Rei D. João $I$, publicada por Francisco Maria Esteves Pereira, Lisboa, Academia das Sciencias de Lisboa.

Zurara, Gomes Eanes de, Crónica dos Feitos da Guiné . dir. L. Albuquerque, coment. e transc. T. S. Soares, (1989), Lisboa, Publicações Alfa.

\section{Estudos}

Abreu, C. de (2000), Capitulos de História Colonial. Belo Horizonte, Itatiaia/Publifolha.

Adamson, M. W. (2004), Food in Medieval Times, Westport, Connecticut, London, Greenword Press.

Alarcão, J. de (2008), Coimbra. A montagem do cenário urbano, Coimbra, Imprensa da Universidade.

Albuquerque, L. (dir.) e Soares, T. S. (comentário e transcrição em port. actual) (1989), Gomes Eanes de Zurara. Crónica dos Feitos da Guiné, Lisboa, Publicações Alfa 
Alexandre-Bidon, D. (2001), «Festim de Imagens e 'aperitivos' iluminados» in J. L. Flandrin, M. Montanari (dirs.), História da Alimentação, 2, Da Idade Média aos tempos actuais, trad. port., Lisboa, Terramar: 133-140.

Algranti, L. (2004), “Os livros de receitas e a transmissão da arte luso-brasileira de fazer doces (séculos XVII-XIX)”, in Actas do III Seminário Internacional sobre a História do Açúcar: O açúcar e o cotidiano. Funchal (Portugal). Centro de Estudos de História do Atlântico/Secretaria Regional do Turismo e Cultura, 127-143.

Algranti, L. (2005), "Os doces na culinária luso-brasileira: da cozinha dos conventos à cozinha da casa brasileira séculos XVII a XIX", Anais de História de Além-Mar, Universidade de Lisboa, IV: 139-158.

Algranti, L. (2010), "História e historiografia da alimentação no Brasil (séculos XIVXIX)” in A. P. Campos; G. V. Silva, M. B. Nader, S. P. Franco, S. A. Feldman, A cidade à prova do tempo: vida cotidiana e relaçôes de poder nos ambientes urbanos. Vitória, GM Editora: 131-154.

Allard, J. (1990), «Le corps vu par les traités de diététique dans l'Espagne du Siècle d'Or», in A Redondo (ed.), Le Corps dans la Société Espagnole des XVI et XVII Siècles, Colloque International (5-8 octobre 1988), Paris, Publications de la Sorbonne: 96-97.

Almeida, A. A. Marques de (1986), “O Perdão Geral de 1605”, Primeiras Jornadas de História Moderna. Lisboa, 1986. Actas, vol. 2, Lisboa, Centro de História da Universidade de Lisboa, 885-898.

Almeida, L. F. (1987), Os Colégios da Alta Coimbrã - Episódios da Vida Académica, Coimbra, Arquivo da Universidade de Coimbra: 30-32.

Almeida, M. L. de, Brochado, I. F. da C., Dinis, A. J. D. (1960), Monumenta Henricina, Vol. 1, Comissão Executiva das Comemorações do V Centenário da Morte do Infante D. Henrique, Coimbra;

Alves , M. L. G. (2013), Aprendizagem de Ofícios pelas Crianças Confiadas à Real Casa dos Expostos de Lisboa (1777-1812), Lisboa, Dissertação de Mestrado em História, especialidade de História Moderna e Contemporânea, apresentada à Faculdade de Letras da Universidade de Lisboa.

Amorim, R. (1987), Da Mão para a Boca. Para uma História da Alimentação em Portugal, Lisboa, Edições Salamandra.

Andò, V. (2004), "Vino e sistema di valori nei poemi omerici”, Talassa. Genti e culture del Mediterraneo antico 1: 87-99.

Andrade, M. do C. R. de (1996), "As Artes de Mesa e a ourivesaria de corte em Portugal na $1^{\text {a }}$ metade do século XVI", Encontro sobre as Transformações na Sociedade Portuguesa, 1480-1570, Lisboa, Fundação das Casas de Fronteira e Alorna: 1-13

André, J. (1981), L'alimentation et la cuisine à Rome. 2. ed. Paris, Les Belles Lettres.

Andreau, J. (2010), Léconomie du monde romain. Paris, Ellipses.

Anselmino, L. et alii (1986), "Ostia: Terme del Nuotatore”, in A. Giardina (ed.), Società romana e impero tardoantico, III. Roma-Bari, Editori Laterza: 45-81.

Araújo, A. C. (2001-2002), "Corpos Sociais, Ritos e Serviços Religiosos numa Comunidade Rural. As Confrarias de Gouveia na Época Moderna”, Revista Portuguesa de História, tomo 35, Coimbra. 
Archambault, P. (1967), “The Analogy of the 'Body' in Renaissance Political Literature”, Bibliothèque d'Humanisme et Renaissance, XXIX : 21-53.

Ariès, P. (1973), L'enfant et la vie familiale sous l'Ancien Régime, Paris, Seuil.

Arnaut, S. D. (1967), "A arte de comer em Portugal na Idade Média”, in S. D. Arnaut e G. Manupella (eds.), O "Livro de Cozinha" da Infanta D. Maria de Portugal, Coimbra, por ordem da Universidade.

Arnaut, S. D. (1986), A Arte de Comer em Portugal na Idade Média, Lisboa, Imprensa Nacional-Casa da Moeda.

Arnaut, S. D. (1987, 2a ed.), "A Arte de Comer em Portugal na Idade Média”, in S. D. Arnaut e G. Manupella (eds.), O "Livro de Cozinha" da Infanta D. Maria de Portugal, Lisboa, Imprensa Nacional-Casa da Moeda.

Aron, J (1995), “A cozinha: um cardápio do século XIX”, in J. Le Goff, P.Nora (orgs.), História: novos objetos. 4. ed. Rio de Janeiro, Francisco Alves: 160-185.

Aron, J. (1989), “Cozinha”, in R. Romano (dir.), Enciclopédia Einaudi, v. 16: HomoDomesticação-Cultura Material. Lisboa, Imprensa Nacional - Casa da Moeda: 281-304.

Arruda, A. M. (2003), “Contributo da colonização fenícia para a domesticação da terra portuguesa”, in C. Gómez Bellard (ed.), Ecohistoria del paisage agrario la agricultura fenicio-púnica en el mediterrâneo. Universitat de València, Valência, 205-217.

Asfora, W., Saldarriaga, G. (2013); "A decade of research in Ibero-America", FoodE'History, 10, 2: 205-218.

Augusto, O. C. G. S. (2012), A Praça de Coimbra e a afirmação da baixa: origens, evolução urbanística e caracterização social, Dissertação de Mestrado em História apresentada à Faculdade de Letras da Universidade de Coimbra.

Aurell, M. A., Dumoulin, O., Thelamon, F. (coord.) (1992), La Sociabilité à Table. Commensalité et Convivialité à Travers les Âges, Actes du Colloque de Rouen, 1417 novembre 1990, Rouen, Publications de l'Université de Rouen.

Aymard, J. (1961), Les chasses romaines; des origines à la fin du siècle des Antonins. Paris, E. de Boccard.

Badinter, E.(1985), Um amor conquistado: o mito do amor materno, Rio de Janeiro, Nova Fronteira.

Baião, A. (1938) Episódios Dramáticos da Inquisição Portuguesa, III, Lisboa, Seara Nova;

Balmelle, C. et alii (1990), Recherches franco-tunisiennes sur la mosaïque de l'Afrique antique, v. 1: Xenia. Roma, École Française de Rome. (Collection de l'École Française de Rome, 125).

Banquets et Manières de Table au Moyen Age (1996), Actes du Colloque du Centre Universitaire d'Etudes et de Recherches Médiévales d'Aix, Aix-en-Provence.

Barboff, M. (2011), A tradição do pão em Portugal, Lisboa, Clube do Coleccionador dos Correios.

Barbosa, M. A.; Melo, M. B. de; Júnior, R. S. S.; Brasil, V. V.; Martins, C. A. e Bezerra, A. L. Q. (2004), "Saber popular: sua existência no meio universitário". Rev. bras. enferm., 57(6):715-719. 
Barrau, J. (1989), “Animal”, in R. Romano (dir.), Enciclopédia Einaudi, v. 16: HomoDomesticação-Cultura Material. Lisboa, Imprensa Nacional - Casa da Moeda: 225-239.

Barros, A. L. (2013), As receitas de cozinha de um frade português do séc. XVI, Coimbra, Imprensa da Universidade de Coimbra.

Barton, I. M. (1996), Roman Domestic Buildings. Exeter, University Exeter Press.

Beirante,M.A.(1999), "Ritos alimentares em algumas confrarias portuguesas medievais”, Piedade Popular: sociabilidades, representações, espiritualidades. Actas do Colóquio Internacional (FCSH), Lisboa, Terramar: 559-570.

Beirante, M. A. (2008), "O vínculo cidade-campo na Évora quinhentista”, O Ar da Cidade. Ensaios de História Medieval e Moderna, Lisboa, Colibri: 295-306.

Bérard, C. (1983), "Iconographie, iconologie, iconologique”, Études de Lettres / Revue de la Faculté de Lettres de l'Université de Lausanne, 4: 5-37.

Bertelli, S. (1990), Il Corpo del Re. Sacralità del Potere nel'Europa Medievale e Moderna, Florença, Ponte Alle Grazie.

Bertini, G. (2000), " The marriage of Alessandro Farnese and D. Maria of Portugal in 1565 : Court life in Lisbon and Parma”, in K- J.P. Lowe (ed.), Cultural links between Portugal and Italy in the Renaissance, Oxford, Oxford University Press:45-59.

Beschaouch, A. (1966), "La mosaïque de chasse à l'amphithéâtre découverte à Smirat en Tunisie”, Comptes Rendus de l'Académie des Inscriptions et Belles-Lettres: 150-157.

Beschaouch, A. (1977), "Nouvelles recherches sur les sodalités de l'Afrique Romaine", Comptes Rendus de l'Académie des Inscriptions et Belles-Lettres: 486-506.

Beschaouch, A. (1987), "A propos de la mosaïque de Smirat”, Atti del IV Convegno di Studio (Sassari, 12-14 dicembre 1986), L'Africa Romana. Sassari, Gallizzi: 677-680.

Bethencourt, F. (1994), “Un univers saturé de magie: L'Europe Méridionale”, Magie et sorcellerie en Europe du Moyen Age à nos jours, Paris, Armand Colin: 159-194.

Bethencourt, F., Castro , A. P. de, (1998) , Padre António Vieira, 1608-1697 : catálogo da exposição : Novembro 1997 - Fevereiro 1998, Lisboa, Biblioteca Nacional de Portugal.

Biedermann, H. (1993), Diccionario de símbolos. Barcelona, Paidós.

Birlouez, E. (2011), À la table des seigneurs, des moines et des paysans du Moyen Âge, Tours, Éditions Ouest-France.

Blanc, N., Nercessian, A. (1992), La cuisine romaine antique. Grenoble, Glénat.

Blanchard-Lemée, M.et alii (1996), Mosaics of Roman Africa; floor mosaics from Tunisia. London, British Museum Press.

Boardman, J. et alii (1988), The Cambridge Ancient History. Vol. IV. Persia, Greece and the Western Mediterranean c. 525-479 B. C. Cambridge University Press. Cambridge.

Bortolini, G.A et allii. (2010). Guia alimentar para crianças menores de 2 anos, Ministério da Saúde.

Bosi, L. M., Machado, M. T. (2005), “Amamentação: um resgate histórico”, Cadernos Esp Escola Saúde Pública Ceará 1(1). 
Braga, I. D. (1998a), "A Circulação e a Distribuição dos Produtos”, in J. J. A. Dias (coord.) Portugal do Renascimento à Crise Dinástica, in J. Serrão e A. H. de Oliveira Marques (dir.), Nova História de Portugal, vol. 5, Lisboa, Presença

Braga, I. D. (1998b), "A Produção Artesanal”, in J. J. A. Dias (coord.) , Portugal do Renascimento à Crise Dinástica, in J. Serrão e A. H. de Oliveira Marques (dir.), Nova História de Portugal, vol. 5, Lisboa, Presença

Braga, I. D. (2000), Portugal à Mesa. Alimentação, Etiqueta e Sociabilidade, 1800-1850, Lisboa, Hugin

Braga, I. D. (2002-2003), “A Alimentação das Minorias no Portugal Quinhentista”, Revista Portuguesa de História, tomo 36, vol. 1, Coimbra.

Braga, I. D. (2002), “A Mesa”, in Portugal e a Instauração do Liberalismo, in J. Serrão e A. H. de Oliveira Marques (dir.), Nova História de Portugal, vol. 9, Lisboa, Presença, pp. 493-508.

Braga, I. D. (2004a), Do Primeiro Almoço à Ceia. Estudos de História da Alimentação, Sintra, Colares Editora

Braga, I. D. (2006), Os Menus em Portugal. Para uma História das Artes de servir à Mesa, Lisboa, Chaves Ferreira Publicações.

Braga, I. D. (2007), “À mesa com Grão Vasco: para o estudo da alimentação no século XVI”, Màthesis 16: 4-27.

Braga, I. D. (2010), Sabores do Brasil em Portugal. Descobrir e transformar novos alimentos (séculos XVI-XXI), São Paulo, Editora Senac.

Braga, I. D. (2012a), "Les Familles de Chrétiens Nouveaux et la Possession d'Objectes Religieux (XVII et XVIII siècles)”, in F. Ammannati (dir), Religione e Istituzioni Religiose nell'Economia Europea 1000-1800, Florença, Firenze University Press.

Braga, I. D. (2012b), Bens de Hereges. Inquisição e Cultura Material (Portugal e Brasil, séculos XVII e XVIII), Coimbra, Imprensa da Universidade de Coimbra.

Braga, P. D. (1992), “Dois Surtos de Peste em Lisboa: 1579-1581”, Revista da Biblioteca Nacional, 2. ${ }^{\text {a }}$ série, vol. 7, n. ${ }^{\circ}$ 2, Lisboa.

Braga, P. D. (2003-2004), “Comércio Alimentar na Lisboa Pombalina”, Revista Portuguesa de História, tomo 26, vol. 2, p. 8.

Braga, P. D. (2004b), Leite. Biografia de um Género Alimentar, Sintra, Colares Editora.

Braga, T. (1885), O Povo Português nos seus costumes, crenças e tradições. 2 vols., Lisboa, Livraria Ferreira.

Brasil (2005). Guia alimentar para crianças menores de 2 anos, Brasília, Ministério da Saúde.

Braudel, F. (1970), “Alimentation et catégories de l'histoire”, Cahiers des Annales, 28, Pour une Histoire de l'Alimentation: 15-19.

Braudel, F.(1979), Civilisation matérielle, Economie et Capitalisme XVe-XVIIIe siècle, I Les Structures du Quotidien, Paris, Armand Colin.

Braunstein, F1., Pépin J.-F., (1999) La place du corps dans la culture occidentale, PUF.

Bretas, A. J. F. (1838), Dissertação inaugural sobre a utilização do aleitamento maternal $e$ os inconvenientes que resultam do desprezo deste dever, Tese de doutoramento apresentada à Faculdade de Medicina do Rio de Janeiro, Rio de Janeiro. 
Brillat-Savarin,J.A. (2009, 6ª ed.), A fisiologia do gosto. São Paulo, Companhia das Letras.

Bruegel, M., Laurioux B. (dir.) (2002), Histoire et identités alimentaires en Europe, Paris, Hachette

Bruegel, M., Laurioux, B. (dir.) (2002), La faim et l'abondance. Histoire de l'alimentation en Europe.

Bruit, H.; Abrahão, E. M., Leanza, D. D., Abrahão, F. (2007), Delícias de Sinhá - História e receitas culinárias da segunda metade do século XIX e início do XX Campinas. Arte Escrita Editora.

Buarque de Holanda, S. (2008), Caminhos e Fronteiras. São Paulo, Cia. das Letras.

Buescu, A. I. (1996), Imagens do Principe. Discurso Normativo e Representação, Lisboa, Cosmos.

Buescu, A. I. (2007), Catarina de Áustria (1507-1578), Infanta de Tordesilhas, Rainha de Portugal, Lisboa: A Esfera dos Livros.

Buescu, A. I. (2011), “À mesa do rei. Cultura alimentar e consumo no século XVI”, in A. I. Buescu e D. Felismino (coords.), A Mesa dos Reis de Portugal. Ofícios, consumos, cerimónias e representações, Temas e Debates - Círculo de Leitores, 304-317.

Buescu, A. I. e Felismino, D. (2011), "Sobre a construção de um campo historiográfico”, in A. I. Buescu e D. Felismino (coords.), A Mesa dos Reis de Portugal. Ofícios, consumos, cerimónias e representações, Temas e Debates - Círculo de Leitores, 14-24.

Burguière, A. (1986), «Alimentation», in, A. Burguière (dir.) Dictionnaire des Sciences Historiques, Paris, PUF, 7-11.

Burke, P. (2004), Testemunha ocular; História e imagem. Bauru, SP, EDUSC.

Burkert, W. (1993), Religião Grega na Época Clássica e Arcaica. Fundação Calouste Gulbenkian. Lisboa.

Bustamante, R. M. da C. (2003), "Em torno da mesa da elite na Roma Antiga”, Caliope 11: 95-111.

Bustamante, R.M. da C. (2006), "Práticas culturais no Império Romano: entre a unidade e a diversidade”,in N. M. Mendes e G. V. da Silva (orgs.), Repensando o Império Romano; perspectiva socioeconômica, politica e cultural. Rio de Janeiro - Vitória, Mauad - EDUFES, 109-136.

Bustamante, R. M. da C.a (2005) "Sangue, suor e prestígio social: o mosaico de Magerius", in M. M. Carvalho et alii (orgs.), Relações de poder, educação e cultura na Antiguidade e Idade Média. São Paulo, Solis, 169-178.

Caetano, M. (1959), A História da Organização dos Mesteres na Cidade de Lisboa, Braga.

Callender, M. H. (1965), Roman amphorae, with an index of stamps. Oxford, OUP.

Câmara Cascudo, L. da (2007, 3a ed.), História da Alimentação no Brasil. , Global Editora. São Paulo.

Camelo, J. S. Jr; Heck, A. R. (2007), "Nutrição do recém-nascido a termo - apologia da amamentação”, in J. P. Monteiro e J. S. Jr Camelo, H. Vanucchi (coord.), Caminhos da nutrição e terapia nutricional: da concepção à adolescência, Rio de Janeiro, Guanabara Koogan.

Camporesi, P. (1980) Alimentazione, folclore, società. Parma, Pratiche. 
Campos, M. A. A (2010), "O rural e o urbano nas freguesias de Coimbra nos séculos XIII e XIV”, Revista Portuguesa de História XLI, 157-174.

Campos, M. A. A. (2012), Santa Justa de Coimbra na Idade Média: o espaço urbano, religioso e socio-económico, Coimbra, Faculdade de Letras.

Campos, M. A. A. (2013), "A mulher da paróquia de Santa Justa de Coimbra na Baixa Idade Média: o retrato possível das suas ocupações, relações e afectos”, in J. S. Telechea, B. A. Bolumburu e A. A. Andrade (eds.), Ser Mujer en la Ciudad Medieval Europea, Logroño: Instituto de Estudios Riojanos, 215-232

Camps-Farber, H. (1953), L'olivier et l'huile dans l'Afrique Romaine, Alger, Imprimerie Officielle.

Canesqui, A. M. (1988), "Antropologia e alimentação”, Rev. Saúde Pública, 22(3):207216.

Caparti, A. e Coron (2001), Sabine "Prélude à une histoire de la table», in Livres en Bouche. Cinq siècles d'art culinaire français, du quatorzième au dix-huitième siècle, Paris, Herman, Éditeurs des Sciences et des Arts / Bibliothèque Nationale de France :15-31.

Carandini, A. (1983), "Pottery and African economy", in P. Garnsey, K. Hopkins, C. R. Whittaker (eds.), Trade in the ancient economy. London, Chatto \& Windus - The Hogarth Press, 145-162.

Carasa Soto, P. (1991), Historia de la Beneficencia en Castilla y Leon. Poder y Pobreza en la Sociedad Castellana, Valladolid, Universidad de Valladolid.

Carcopino, J. (s/d), "A cena”, in J. Carcopino, A vida quotidiana em Roma no apogeu do Império Romano. Lisboa, Edição "Livros do Brasil”, 318-332.

Cardoso, C. F. (2011), “Existiu uma 'economia romana'?”, Phoinix 17 (1): 15-36.

Cardoso, J. M. P. (2008), Cerimonial da Capela Real. Um manual litúrgico de D. Maria de Portugal (1538-1577) Princesa de Parma, Lisboa, Imprensa Nacional-Casa da Moeda/Fundação Calouste Gulbenkian.

Carvalho, R. S. de (2012), "O Regimento do Ofício de Ladrilhadores da Cidade de Lisboa", Revista de Artes Decorativas, 5: 79-105.

Carvalho, J. (2008) O Elucidarium. Um estudo sobre a reforma, o diabo, o fim dos tempos, Dissertação de mestrado apresentada à Faculdade de Filosofia, Línguas e Ciências Humanas da Universidade de São Paulo, 99-113.

Carvalho, M. do S. F. de (2007), Poesia de Agudeza em Portugal. Estudo retórico da poesia lírica e satírica escrita em Portugal no século XVII, São Paulo, Humanitas Editorial; Edusp; Fapesp.

Cascudo, L. C. (2004, 3a ed.), História da alimentação no Brasil, São Paulo, Global.

Casimiro, T. (2011), Faiança Portuguesa na Ilhas Britânicas (dos finais do século XVI aos inícios do século XVIII), Tese de Doutoramento apresentada à Universidade Nova de Lisboa, Lisboa.

Cassien, J. (2011) Institutions Cénobitiques, J.-Cl. Guy (ed. e trad.), SC 109 (1961 1ª ed.), le Cerf.

Castelo Branco, F. (1960), “O peixe na alimentação da Lisboa seiscentista”, in Revista Municipal, 90 (Setembro): 36-52. 
Castelo Branco, F. (1990) "A Alimentação", in Lisboa Seiscentista, Lisboa, Horizonte: 105-117.

Castilho, S. D.; Barros, A. de A. F.; Cocetti, M. (2010), "Evolução histórica dos utensílios empregados para alimentar lactentes não amamentados", Ciência e Saúde Coletiva 15(supl.1):1401-1410.

Castilho, S. D., Barros, A. de A. F. (2010), “The history of infant nutrition”, Jornal de Pediatria 86(3):179-188.

Castllo Gómez, A. (2003), "Escrito en Prisión. Las Escrituras Carcelarias en los siglos XVI y XVII”, Península. Revista de Estudios Ibéricos, n. ${ }^{\circ}$ 0, 147-170.

Castro, I. de O. e, Braga, I. M. R. M. D (2012), “Uma Escrita no Feminino Diferente: os Manuscritos Conventuais Portugueses da Época Moderna”, Congreso Internacional Escritoras entre Rejas. Cultura Conventual Femenina en la España Moderna, Madrid.

Castro, I.de O. e (1997), "Introdução", in Apício, O livro de cozinha de Apício. Sintra, Colares: 13-61.

Castro, I.de O. e (2012), "Discursos e rituais na mesa romana: luxo, moralismo e equívocos”, in C. I. L. Soares e P. B.Dias (coords.), Contributos para a bistória da alimentação na Antiguidade. Coimbra, Centro de Estudos Clássicos e Humanísticos da Universidade de Coimbra, 69-79.

Castro, J. de (2006), Geografia da Fome. Rio de Janeiro, Civilização Brasileira.

Castro, J., (1965, 3ºd.) Ensaios de biologia social, São Paulo, Brasiliense.

Catarino, M. M. (2002), "A carne e o peixe nos recursos alimentares das populações do Baixo Tejo”, in M. Alarcão, L. Krus, M. A. Miranda (coord.), Animalia. Presença e Representações,. Lisboa, Edições Colibri, 49-59.

Cavaciocchi, S.(dir.) (1997), Alimentazione e Nutrizione secc. XIII-XVIII. Atti della "Ventottesima Settimana di Studi" do Istituto Internazionale di Storia Económica "F. Datini”- Prato, 22-27 aprile 1996, Florença, Le Monnier.

Certeau, M. de (1990), L'Invention du Quotidien, nouvelle version revue et augmentée, 2 vols., Paris, Gallimard.

Certeau, M. de (1998, 2a ed.), "No fundo, a cozinha me inquieta...”, in M. de Certeau, $A$ invenção do cotidiano, v. 2: Morar, cozinhar. Petrópolis, RJ, Vozes, 298-332.

Certeau, M. de (1998), "O pão e o vinho", in M. de Certeau, A invenção do cotidiano, v. 22: Morar, cozinhar. Petrópolis, RJ, Vozes, 131-149.

Cherry, D. (1998), Frontier and society in Roman North Africa. Oxford, Clarendon Press.

Christol, M., Nony, D. (1995), Rome et son Empire. Paris, Hachette.

Cirlot, J.-E. (1985), Diccionario de símbolos. 6. ed. Barcelona, Labor.

López-Salazar Codes, A.I.. (2010), Inquisición Portuguesa y Monarquía Hispánica en Tiempos del Perdón General de 1605, Évora, Universidade de Évora, Centro Interdisciplinar de História, Culturas e Sociedades, Lisboa, Colibri.

Coelho, M.H. da C. (1990a), “A mulher e o trabalho nas cidades medievais portuguesas”, Homens, Espaços e Poderes. Séculos XI- XVI, I, Notas do Viver Social, Lisboa, Livros Horizonte, 37-59. 
Coelho, M.H.da C.(1990b), “A propósito do foral de Coimbra de 1179”, Homens, Espaços e Poderes. Séculos XI-XVI, I, Notas do Viver Social, Lisboa, Livros Horizonte, 105120.

Coelho, M. H. da C. (1990c), "Apontamentos sobre a comida e a bebida do campesinato coimbrão em tempos medievos", Homens, Espaços e Poderes (séculos XI-XVI), I Notas do Viver Social, Lisboa, Livros Horizonte, 9-22.

Coelho, M. H. da C. (1990d), "Receitas e Despesas do Mosteiro de Santa Cruz de Coimbra, em 1534-1535”, Homens, Espaços e Poderes (séculos XI-XVI), II Dominio Senhorial, Lisboa, Livros Horizonte, 93-119.

Coelho, M. H. da C. (1992), "Coimbra Trecentista. A Cidade e o Estudo", Biblos, LXVIII: 335-356.

Coelho, M. H. da C. (1993), A Feira de Coimbra no contexto das Feiras Medievais Portuguesas, Coimbra, Inatel.

Coelho, M. H. da C. (1995), "A pesca fluvial na economia e sociedade medieval portuguesa”, Cadernos Históricos, VI: 81-102.

Coelho, M. H. da C. (1998), Ócio e Negócio em Tempos Medievais, Coimbra, Inatel.

Coelho, M. H. da C. (2003a), "Coimbra medieval: uma cidade em maturação", in Adília Alarcão (coord.), Coleç̧ão de ourivesaria medieval, séculos XII-XV, Lisboa, Instituto Português de Museus.

Coelho, M. H. da C. (2003b), “Coimbra em Tempos Medievais (Séculos XIV e XV)”, José d'Encarnação (ed.), A História Tal Qual se Faz, Coimbra/Lisboa, Faculdade de Letras/Colibri, 65-78.

Coelho, M. H. da C. (2005a), “Ao correr do vinho: governança e desgovernança dos homens", Portefólio, 1: 112-121.

Coelho, M. H. da C. (2005b), "Nos Alvores da História de Coimbra - D. Sesnando e a Sé Velha”, Sé Velha de Coimbra. Culto e Cultura, Coimbra, Catedral de Santa Maria de Coimbra, 11-39.

Coelho, M. H. da C. (2005c), D. João I. O que re-colheu Boa Memória, Lisboa, Círculo de Leitores.

Coelho, M. H. da C. (2008), D. João I . O que re-colheu Boa Memória, Lisboa, Temas e Debates

Coelho, M. H. da C. (2010), “A festa - a convivialidade”, in B. V. Sousa (coord.), História da Vida Privada em Portugal, A Idade Média. Lisboa, Círculo de Leitores, 144169.

Coelho, M. H. da C. (2011), D. Filipa de Lencastre. A Inglesa Rainha. 1360-1415, Vila do Conde, Quidnovi.

Coelho, M. H. da C. (2013), O Municipio de Coimbra: Monumentos Fundacionais, Coimbra, Câmara Municipal e Imprensa da Universidade.

Coelho, M. H. da C. e Magalhães, J. .R. (2008, 2a ed.), O Poder Concelbio: das origens às cortes constituintes. Notas de história social, Coimbra, CEFA.

Coelho, M. H. da C. e Riley, C. (1988a), "Sobre a Caça Medieval”, in Estudos Medievais, 9: 221-267. 
Coelho, M. H. da C. (1988b), O Baixo Mondego nos Finais da Idade Média, Lisboa, Imprensa Nacional - Casa da Moeda.

Connerton, P. (1993), Como as Sociedades Recordam, Oeiras, Celta Editora.

Consiglieri, C. e Abel, M. (1999), A tradição Conventual na doçaria de Lisboa, Sintra, Colares Editora.

Corbier, M. (1998), “A fava e a moréia: hierarquias sociais dos alimentos em Roma”, in J. L. Flandrin, M. Montanari (dir.), História da alimentação. São Paulo, Estação Liberdade, 217-237.

Corção, M. (2012), "A influência do gosto da cozinha portuguesa na História da alimentação no Brasil de Câmara Cascudo", Estudos Históricos, Rio de Janeiro, 25, 50: 408-425, (http://bibliotecadigital.fgv.br/ojs/index.php/reh/article/ viewArticle/3965, consultado em 2013.10.26).

Cosman, M. P. (1976), Fabulous Feasts. Medieval Cookery and Ceremony, Nova Iorque, George Braziller.

Costa, J. P. da (1994), Vereações da Câmara Municipal do Funchal. Século XV, Região Autónoma da Madeira, Funchal.

Crespo, J. e Hasse, M. (1981), “A Alimentação no Real Colégio dos Nobres de Lisboa (1776-1831)”, in Revista de História Económica e Social, 7 (Janeiro - Julho): 93-104.

Cuer, M. (1996) Banquets et Manières de Table au Moyen Age, Actes du Colloque du Centre Universitaire d'Etudes et de Recherches Médiévales d'Aix, Senefiance, 38.

Cunha, M. S. da (2011), "Mesa e aprovisionamento na Casa dos duques de Bragança”, in A. I. Buescu e D. Felismino (coords.), A Mesa dos Reis de Portugal, Lisboa, Temas e Debates - Círculo de Leitores: 64-81.

Cunha, R. da S. (1972), "Subsídios para a História da Conservação do Peixe em Portugal do Século XII ao XVI", in Boletim da Biblioteca da Universidade de Coimbra, XXIX: 29-39

Cury, M. T. F. (2009 2aed.), "Aleitamento materno”, in E. Accioly, C. Saunders e E. M. A. Lacerda (eds.), Nutrição em obstetrícia e pediatria, Rio de Janeiro, Cultura Médica, Guanabara Koogan.

D'arms, J. H. (2004), “The culinary reality of roman upper-class convivia: integrating texts and images", Comparative Study of Society and History 46 (3): 428-450.

D’Azevedo, J. L. (1925), Cartas do Padre António Vieira, Coimbra, Imprensa da Universidade.

D’Encarnação, J. (2011), "Do património gastronómico”, in J. R. Ferreira (coord.), Emergir de crenças e presenças. Alguns temas de Sociedade e Cultura. Colecção Fluir Perene, Coimbra.

D’Encarnação, J.. (2012), “Cidade, gastronomia e património”, Revista Memória em Rede, Pelotas, v. 2, n. 7, Jul./Dez: 1-12.

Dalby, A. (1996), Siren Feasts. A History of Food and Gastronomy in Greece. London \& New York.

Dalby, A. (2000), "Topikos oinos: the Named Wines of Old Comedy", in D. Harvey, J. Wilkins (eds.), The Rivals of Aristophanes. Studies in Athenian Old Comedy. 
London, Duckworth-The Classical Press of Wales, 397-406.

Dalby, A., Grainger, S. (2000), The classical cookbook. London, British Museum Press.

Dana, M.(2012), "Le 'centre' et la 'périphérie' en question: deux concepts à recevoir pour les diasporas”, Pallas 89: 57-76.

Danvila y Burguero, A. (1900), Don Cristobal de Moura, Primer Marqués de Castel Rodrigo (1538-1613), Madrid, Real Academia de la Historia.

Daupias, N. (1957), "A exportação do sal pelo porto de Lisboa no princípio do século XVIII (Subsídios para a história do comércio do sal e do movimento do porto de Lisboa)", in Boletim Clinico dos Hospitais Civis de Lisboa, Lisboa, 21:157-168.

Decret, F., Fantar, M. H. (1988, 2a ed.), L'Afrique du Nord dans l'Antiquité; histoire et civilisation des origines au $\mathrm{V}^{\mathrm{e}}$ siècle. Paris, Payot.

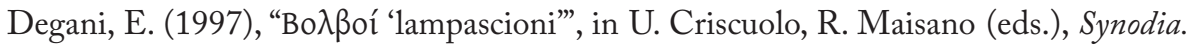
Studia humanitatis Antonio Garzya septuagenario ab amicis atque discipulis dicata. Napoli, M. D’Auria Editore, 233-236.

Del Ciampo, L. A.; Ricco, R. G.; Ferraz, I. S.; Daneluzzi, J. C.; Martinelli Junior, C. E. (2008), "Aleitamento materno e tabus alimentares", Revista Paulista de Pediatria 26(4):345-349.

Desportes, F. (2001), "Os ofícios da alimentação", in J.-L. Flandrin e M. Montanari (org.), História da Alimentação, vol. 2, Da Idade Média aos tempos actuais, Lisboa, Terramar, 43-55.

Dessau, H. (1963). Inscriptiones Latinae Selectae (ILS). Berlin, Weidmannos, 3 v.

Detienne, M. (1995 4a ed.), “O mito: Orfeu no mel”, in J. Le Goff, P. Nora, (orgs.), História: novos objetos., Rio de Janeiro, Francisco Alves, 52-67.

Dias, J. J. A. (1992), "Un Banquet Royal au Portugal au XVI ème siècle”, in M. Aurell et alli (coord.), La Sociabilité à Table. Commensalité et Convivialité à Travers les Ages (Actes du Colloque de Rouen. 14-17 Novembre 1990), Rouen, Publications de l'Université de Rouen, 178: 155-158.

Dias, J. J. A. (org) (2004-2006), Chancelarias Portuguesas. D. João I, 4 vols, Lisboa, Centro de Estudos Históricos - Universidade Nova de Lisboa, (citada CHDJ).

Dias, J. J. A. (org.) (1999), Chancelarias Portuguesas. D. Duarte, vol. II, Lisboa, Centro de Estudos Históricos - Universidade Nova de Lisboa, (citada CHDD).

Dias, P. B. (2006) "O Catálogo dos sete pecados mortais- a sua presença na cultura antiga e contemporânea”, Boletim de Estudos Clássicos 45: 95-99.

Dias, P. B., (2012) "Paulo e a controvérsia sobre os alimentos permitidos aos cristãos: a mesa entre dois mundos", in Ramos, J. et al. (coord.), Paulo de Tarso: grego, romano, judeu e cristão, Classica Digitalia, 115 - 129

Dias, P.B. (2008) “A linguagem dos alimentos bíblicos: sentidos para fome e a abundância”, Humanitas, 60: 157-175.

Díaz y Díaz, M. ed. (1958), Eutrópio de Valência, Eutropii Abbatis de Octo Vitiis ad Petrum Papam, Analecta Wisigothica I, Salamanca, 27-35.

Dolhnikoff, M. (2012), José Bonifácio de Andrada e Silva, São Paulo, Companhia das Letras. 
Dória, C. A. (2000), A formação da culinária brasileira. São Paulo, Publifolha.

Dosi, A., Schnell, F. (1986), Le abitudini alimentari dei romani. Roma, Quasar.

Duarte, M. D., 2005, “ "Sacrum Convivium”. Formas e conteúdos da cei do rei de Portugal na Idade Moderna a partir das figurações icónicas”, in De Arte, Revista de Historia del Arte, 4, Universidade de Léon, 4: 89-120.

Dunbabin, K.M.D. (1999), Mosaics of the Greek and Roman World. Cambridge, University Press.

Dunbabin, K. M. D. (2003), The roman banquet; images of conviviality. Cambridge, University Press.

Duncan-jones, R. P. (1963), "Wealth and munificence in Roman Africa", Papers of the British School at Rome, 31: 159-177.

Dupont, F. (1989), “Gramática da alimentação e das refeições romanas”, in J.-L. Flandrin, M. Montanari, (eds.), História da alimentação. São Paulo, Estação Liberdade: 199-216.

Edwards, M. W. (1975), "Type-scenes and Homeric Hospitality", Transactions of the American Philological Association 105: 51-72.

Elias, N. (1973), La Civilisation des Moeurs, Paris, Calman Lévy.

Ennaïfer, M. (1996), "Xenia and banquets", in M. Blanchard-Lemée et alii, Mosaics of Roman Africa; floor mosaics from Tunisia. London, British Museum Press: 65-85.

Eucydes, M. P. (2005). Nutrição do lactente: base cientifica para a alimentação saudável, Minas Gerais, Viçosa.

Eutrópio de Valência, Díaz y Díaz, M. ed.(1958), Eutrópio de Valência, Eutropii Abbatis de Octo Vitiis ad Petrum Papam, Analecta Wisigothica I, Salamanca, 27-35.

Fabietti, U. (1989), “Vegetal”, in R. Romano (dir.), Enciclopédia Einaudi, v. 16: HomoDomesticação-Cultura Material. Lisboa, Imprensa Nacional - Casa da Moeda, 210-224.

Fantar, M. H. et alii (1994), La mosaïque en Tunisie. Paris / Tunis, CNRS / Alif.

Faria, M. I. Pericão, M. da G. (1991), "Os fundos bibliográficos dos colégios universitários de Coimbra: algumas sugestões para o seu tratamento técnico", in Universidade(s) História, Memória, Perspectivas, Actas do congresso "História da Universidade", Vol. II. Coimbra, Comissão organizadora do congresso "História da universidade": 183-195.

Faria, M. I. R. de, e Tavares, P. M. (1990), “Aspectos de comer e estar à mesa no século XVII português”, Boletim do Arquivo da Universidade de Coimbra, X: 271-311.

Fentress, E., ed. (2000), Romanization and the City: creation, transformations, and failures (Journal of Roman Archaeology, supp. 38): 221-226.

Ferrão, J. E. M., Loureiro, R. M. (2006), «Plantas viajantes o legado do Novo Mundo» in R. Loureiro (coord.), Plantas Viajantes cores e sabores do Novo Mundo catálogo da /exposição do mesmo nome. Centro Cultural do Lagos.

Ferreira ,J. A. Pinto (1951), Os Mesteirais na Administração Pública em Portugal. Subsídios para o Estatuto desta Classe. Compromisso e Estatuto da Confraria dos Alfaiates do Porto, Porto, Edições Maranus.

Ferreira, J. L.(2008), Gilberto Freyre e Câmara Cascudo: entre a tradição, o moderno e o 
regional. Dissertação de Doutoramento apresentsada à Universidade do Rio Grande do Norte.

Ferreira, M. J. P. C S. (2004), “As Irmandades da Igreja de São Roque. Tempo, Propósito e Legado", Revista Lusófona de Ciência das Religióes, n. o 5-6: 201-215.

Ferrières, M. (2002) Histoire des peurs alimentaires. Du Moyen Âge à l'aube du XXe siècle, Paris, Seuil.

Ferro, J. P.(1996), Arqueologia dos hábitos alimentares. Lisboa, D. Quixote.

Février, P.(1989/1990), Approches du Maghreb Romain; pouvoirs, différences et conflits, 2 t. Aix-en-Provence, ÉDISUD.

Figueiredo, L. R. de A. (1999 2a ed.), O Avesso da Memória. Cotidiano e Trabalho da Mulher em Minas Gerais no século XVIII, Rio de Janeiro, José Olympio Editor.

Finley, M. I. (1980), A economia antiga, Porto, Afrontamento.

Fiocruz (2010), Pesquisa de prevalência de aleitamento materno nos municípios brasileiros. Brasília.

Flandrin, J. (1986), "Pour une histoire du goût", in La Cuisine et la Table. 5000 ans de Gastronomie, $\mathrm{n}^{\circ}$ especial de L'Histoire, 85: 13-19.

Flandrin, J. (2001), “Condimentação, Cozinha e Dietética nos séculos XIV, XV e XVI”, in J.-L. Flandrin, M. Montanari, (eds.), História da Alimentação, 2, Da Idade Média aos tempos actuais, trad. port., Lisboa, Terramar: 95-110.

Flandrin, J. e Montanari, M. (2001), História da Alimentação, vol. 2, Da Idade Média aos tempos actuais, Lisboa, Terramar.

Flint, V. I. J., (1975), The Elucidarius of Honorius Augustodunensis and Reform in Late Eleventh-Century England, Revue bénédictine, 85: 178-189.

Fossier, R. (2010), Gente da Idade Média, Lisboa, Teorema.

Foucher, L. (1964), Hadrumetum. Tunis-Paris.

Fradier, G. (1997), Mosaïques romaines de Tunisie. Tunis, Céres.

Frank, A. G., Gills, B. K., (eds.) (1993), The world system: five hundred years or five thousand?, London-New York, Routledge.

Franklin, A. (1892), La Vie Privée d'Autrefois : Arts et métiers, modes, mours, usages des Parisiens du XVIIe au XVIIIe siècle, d'après des documents originaux ou inédits, 10 vols., Paris, Plon.

Frazão, F. (2003), No Tempo em que Jogar às Cartas era Proibido. Século XV e XVI em Portugal, Lisboa, Apenas Livros.

Frazão, F. (2010), História das Cartas de Jogar em Portugal e da Real Fábrica de Cartas do século XV até à Actualidade, Lisboa, Apenas Livros, 2010.

Freeman, P. (1993), “Romanisation' and Roman material culture”, Journal of Roman Archaeology, 6: 438-445.

Freitas, M. C. S., Minayo, M. C. de S.; Fontes, G. A.V. (2011), "Sobre o campo da Alimentação e Nutrição na perspectiva das teorias compreensivas”, Ciênc. saúde coletiva, 16(1):31-38.

Freyre, G. (1973), Casa Grande e Senzala. Rio de Janeiro, José Olympio. 
Freyre, G. (1993). O Espetáculo das Raças - cientistas, instituições e questão racial no Brasil 1870-1930. São Paulo, Cia. das Letras.

Freyre, G. (1995), Raizes do Brasil. São Paulo, Cia. das Letras.

Freyre, G. (1997), Açúcar. Uma sociologia do doce com receitas de bolos e doces do Nordeste do Brasil. São Paulo, Cia. das Letras.

Freyre, G. (2004), Casa-grande e senzala, Pernambuco, Global.

Freyre, G. (1996 7a. ed.). Manifesto regionalista. Recife, FUNDAJ/ Ed. Massangan.

Funari, P. P. A. (2002), Letras e coisas: ensaios sobre a cultura romana, Campinas, SP, UNICAMP.

Gaffiot, F. (1998 52a ed.), Dictionnaire latin-française, Paris, Hachette.

Gandavo, P. de M. (1964), História da Província Santa Cruz e Tratado da Terra do Brasil, Cadernos de História, São Paulo, Obelisco.

García Soler, M. J. (1995), “I cereali e il pane tra gli antichi greci”, in O. Longo, P. Scarpi (eds.), Nel nome del pane. Trento, 383-390.

García Soler, M. J. (1997), "La alimentación en la época arcaica según la elegía y el yambo", Veleia 14 : 131-143.

García Soler, M. J. (1998), "La comida y la bebida en la lírica arcaica griega”, in J. F. González Castro (ed.), Actas del IX Congreso Español de Estudios Clásicos (Madrid, 27 al 30 de septiembre de 1995), Historia y arqueología 6: 99-104.

García Soler, M. J. (2001), El arte de comer en la antigua Grecia. Madrid.

García Soler, M. J. (2002), "Los vinos de la comedia griega”, Douro - Estudos E̋ Documentos VII (13). Actas del II Symposium de la Asociación Internacional de Historia y Civilización de la Vid y el Vino, Porto-Lamego-Vila Real, 10 a 12 de Septiembre de 2001: 49-64.

García Soler, M.J. (2010), "El vino de los héroes homéricos”, Espacio, tiempo y forma, serie I: Prebistoria y Arqueología n.s. 3: 107-113.

Gardiner, E. (1989) Visions of Heaven and Hell Before Dante, New York.

Garnsey, P. (1988), Famine and food supply in the Graeco-Roman World. Cambridge, University Press.

Garnsey, P. (1998), "As razões da política de aprovisionamento alimentar e consenso político na Antiguidade”, in J.-L. Flandrin, M. Montanari (dir.), História da alimentação. São Paulo, Estação Liberdade, 238-253.

Garnsey, P. (1999), Cities, peasants and food in Classical Antiquity; essays in social and economic history. Cambridge, University Press.

Garnsey, P. D. A., Whittaker, C. R. (eds.) (1978), Imperialism in the Ancient World. Cambridge, University Press.

Garnsey, P., Saller, R. (1987), The Roman Empire; economy, society and culture. BerkeleyLos Angeles, University of California Press.

Gascou, J. (1972), La politique municipale de l'Empire Romain en Afrique Proconsulaire de Trajan à Septime-Sévère. Rome, École Française de Rome. (Collection de l'École Française de Rome). 
Gentili, B., Prato, C. (1988), Poetae Elegiaci. Testimonia et fragmenta. Pars I. Teubner. Leipzig.

Giorgi, R. (2003) Anges et Démons (trd. fr. por Dominique Férault), Paris.

Gomes, J. P. (2013) "Entre o trato e a bagagem: circulação de faiança entre Lisboa e Salvador da Bahia (séculos XVI e XVII)”, Revista de Artes Decorativas, 5: 179-196.

Gomes, R. C. (1995), A Corte dos Reis de Portugal no Final da Idade Média, Lisboa, Difel.

Gomes, R. C. (2011), “Os convivas do rei e a estruturação da corte (século XIII a XVI)”, in A. I. Buescu e D. Felismino (coords.), A Mesa dos Reis de Portugal, Lisboa, Temas e Debates - Círculo de Leitores, 26-43.

Gomes, R. V., (2002), Silves (Xelb) - Uma Cidade do Gharb al-Andalus. Território e Cultura, Lisboa, Trabalhos de Arqueologia, no 23.

Gomes, S.A.(1998), “As ordens mendicantes na Coimbra medieval: notas e documentos”, Lusitania Sacra X/2a série: 149-215.

Gomes, S. A. (2006), "Coimbra - Aspectos da sua paisagem urbana em tempos medievos", Biblos IV: 125-163.

Gomes, S. A. (2007), In Limine Conscriptionis: Documentos, chancelaria e cultura no mosteiro de Santa Cruz de Coimbra (séculos XII a XIV), Coimbra, Palimage.

Gonçalves, I. (1988), “Acerca da alimentação medieval”, in Imagens do Mundo Medieval, Lisboa, Livros Horizonte: 201-213.

Gonçalves, I. (1992-93), “A colheita régia medieval, padrão alimentar de qualidade (um contributo beirão)", Revista da FCSH, 6: 175-189.

Gonçalves, I. (1996), "Defesa do Consumidor na Cidade Medieval: os Produtos Alimentares (Lisboa, séculos XIV-XV)”, Um Olhar sobre a Cidade Medieval, Cascais, Patrimonia: 97-116.

Gonçalves, I. (1997), “À Mesa, com o Rei de Portugal (séculos XII-XIII)”, Revista da Faculdade de Letras. História, Porto, 2a série, XIV : 15-32.

Gonçalves, I. (1999), "Sobre o pão medieval minhoto: o testemunho das Inquirições de 1258”, Arqueologia Medieval, 6: 225-243.

Gonçalves, I. (2000), “A alimentação medieval: conceitos, recursos, práticas”, in Actas dos VI Cursos Internacionais de Verão de Cascais, II, A Alimentação, Cascais, Câmara Municipal de Cascais, 29-48.

Gonçalves, I. (2004), "Entre a abundância e a miséria: as práticas alimentares da Idade Média Portuguesa”, in A. A. Andrade e J. C. V. da Silva (coord.), Estudos Medievais. Quotidiano Medieval: Imaginário, Representação e Práticas, Lisboa, Livros Horizonte, 42-65.

Gonçalves, I. (2007), “A propósito do pão da cidade na Baixa Idade Média”, História da Alimentação, Turres Veteras, IX, Lisboa, Colibri: 49-72.

Gonçalves, I. (2008-2009), "Um dia na cidade medieval", Media Aetas. Cadernos de Estudos Medievais, II Série, 3: 9-32.

Gonçalves, I. (2010), “A alimentação”, in J. Mattoso (dir.), História da Vida Privada em Portugal, Bernardo Vasconcelos e Sousa (coord.), A Idade Média, Maia, Temas e Debates, 226-259. 
Gonçalves, I. (2011), "A mesa itinerante dos nossos primeiros reis”, in A. I. Buescu e D. Felismino (coords.), A Mesa dos Reis de Portugal, Lisboa, Temas e Debates Círculo de Leitores, 82-99.

Goody, J. (1998) Cozinha, Culinária e Classes. Um estudo de sociologia comparativa. Oeiras, Celta Editora.

Greene, K. (1986), The archaeology of the Roman economy. London, Bastford.

Gregorius M. (2005) Moralia in Job, M. Adriaen (ed.), CCEL SL 140 A-B, 2 vols, Brepols.

Grimal, P. (1988), “Os prazeres da cidade”, in P. Grimal, A civilização romana. Lisboa, Edições 70, 255-257.

Grottanelli, C. (1998), "A carne e seus ritos”, in J. L. Flandrin, M.Montanari (dir.), História da alimentação. São Paulo, Estação Liberdade, 121-136.

Guardado, M.C.G. (1999) - A Colegiada de São Bartolomeu de Coimbra em Tempos Medievais. (Das origens ao início do século XV), Coimbra, Faculdade de Letras.

Guedes, A. I. M. (2006), Os Colégios dos Meninos Órfãos (séculos XVII-XIX). Évora, Porto, Braga, Lisboa, Instituto de Ciências Sociais.

Guerreau-Jalabert, A. (1992a), "Aliments symboliques et symbolique de la table dans les romans arthuriens (XII-XIII siècles)», Annales E.S.C., mai-juin, 3 : 561-594.

Guerreau-Jalabert, A. (1992b), «Les nourritures comme figures symboliques dans les romans arthuriens», in M. Aurell, O. Dumoulin e F. Thelamon (org.), La Sociabilité à Table. Commensalité et Convivialitéà Travers les Âges, Actes du Colloque de Rouen, 14-17 novembre 1990, Rouen, Publications de l'Université de Rouen: 35-40.

Guimarães, M. L.L. S. (1988), "Nação e Civilização nos Trópicos: o Instituto Histórico Geográfico Brasileiro e o projeto de uma história nacional”, Revista Estudos Históricos, Rio de Janeiro, 1: 6-27.

Hamilton, C. Y. (2005), Os sabores da lusofonia: encontros e culturas, São Paulo, Senac.

Hammond, P.W.(1996), Food and Feast in Medieval England. Phoenix Mill, Alan Sutton Publishing Limited.

Haro Cortès, M. (2010), "Et no andedes tras vuestra voluntad en comer ni en bever ni en fornicio", in N. Labère (org.) Être à table au Moyen Âge, études réunies et présentées para, Collection de la Casa de Velázquez (115), Madrid: 51-62.

Harris, W., (ed.) (2005), Rethinking the Mediterranean. Oxford, OUP.

Hayes, J. W. (1997), Handbook of Mediterranean Roman Pottery. London, British Museum.

Heath, M. (2000), "Do Heroes Eat Fish? Athenaeus on the Homeric Lifestyle”, in D. Braund, J. Wilkins (eds.), Athenaeus and his World. Reading Greek Culture in the Roman Empire, University of Exeter Press, Exeter, 342-352.

Hémardinquer, J. (1970) Cahiers des Annales, 28, Pour une Histoire de l'Alimentation, Paris, Armand Colin.

Herculano, A. (1985), “Viagem a Portugal dos Cavaleiros Tron e Lippomani (1580)", in J. Custódio e J. M. Garcia (edts.) Opúsculos, vol. 4, Lisboa, Presença, 65-69.

Hernández Íñigo, P. (2006), “Abastecimiento y comercialización de la carne en Córdoba 
a fines de la Edad Media”, Meridies VIII: 73-120.

Hingley, R. (2011), "Globalization and the Roman Empire: the genealogy of 'Empire”, Semata 23: 99-113.

Hitchner, R. B. (1988), "The University of Virginia - INAA Kasserine Archaeological Survey 1982-1986”, Antiquités Africaines 24: 7-41.

Hitchner, R. B. (1990), “The Kasserine Archaeological Survey 1987”, Antiquités Africaines 26: 231-260.

Horden, P., Purcell, N. (2000), The corrupting sea: a study of Mediterranean History. Oxford, Blackwell.

Horden, P., Purcell, N. (2005), "Four years of corruption: a response to critics", in W. Harris (ed.), Rethinking the Mediterranean. Oxford, OUP.

Horta, J. S. (1991), “A representação do Africano na literatura de viagens, do Senegal à Serra Leoa (1453-1508)", Mare Liberum 2: 209-339.

Houaiss, A. e Villar, M. de S. (2001), Dicionário Houaiss da língua portuguesa, Rio de Janeiro, Objetiva.

Huskinson, J., (2000), Experiencing Rome; culture, identity and power in the Roman Empire. London, Routledge/Open University.

Ichisato, S.M.T.; Shimo, A. K. K.(2001), “Aleitamento materno e as crenças alimentares”, Rev Latino-am Enfermagem 9(5):70-76.

Ichisato, S. M. T.; Shimo, A. K. K. (2002) "Revisitando o desmame precoce através de recortes da história”, Rev. Latino-Am. Enfermagem 10(4): 578-585.

Ignacio Pulido, J. (2007), Os Judeus e a Inquisição no Tempo dos Filipes, tradução de Cristina Venâncio, Lisboa, Campo da Comunicação.

Jacques, F. (1992), "La société", in J. Scheid, F. Jacques (eds.), Rome et l'intégration de l'Empire; 44 av. J.-C.-60 ap. J.-C., t. 1: Les structures de l'Empire Romain. 2. ed. Paris, PUF: 291-375.

Job, M. Adriaen ed. (2005), Gregorius Magnus, Moralia, CCEL SL 140 A-B, 2 vols, Brepols.

Joly, M. (1997), Introdução à análise de imagens. Campinas, SP, Papirus.

Jouanna, J. (2008), "Réflexions sur le régime des peuples dans la Grèce classique (Hérodote, I, 133; Hippocrate, Ancienne médicine, ch. 5; Thucydide, I, 6) et sur le

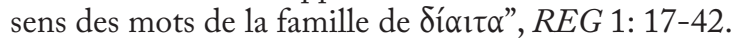

Jouanna, J. (2012), "Dietetics in Hippocratic medicine: definition, main problems, discussion", in J. Jouanna, Greek medicine from Hippocrates to Galen. Selected Papers. Translated by N. Allies. Edited with a reface by Ph. van der Eijk. Brill, Leiden, Boston, 137-153.

Jouffroy, H. (1986), La construction publique en Italie et dans l'Afrique romaine. Strasbourg, Groupe de Recherche d'Histoire Romaine de l'Université des Sciences Humaines de Strasbourg (Études et Travaux 2).

Julien, C. (1994), Histoire de l'Afrique; des origines à 1830. 3. ed. Paris, Payot.

Kachani, A. T; Okuda, L. S.; Barbosa, A. L. R.; Brasiliano, S.; Hochgraf, P. B. (2008), "Aleitamento materno: quanto o álcool pode influenciar na saúde do bebê?" 
Pediatria 30(4):249-256.

Kantorowicz, E. (1985, $1^{\text {a }}$ ed. 1957): Los dos cuerpos del rey. Un estudio de teología política medieval, Madrid, Alianza Editorial.

Keay, S., Terrenato, N., eds. (2001), Italy and the West: comparative issues in Romanization. Oxford, OUP.

Khader, A. B.A. B., (2003), Image in stone; Tunisia in mosaic., Paris, Ars Latina \& Tunisian Agency for the Development of Heritage and Cultural Promotion.

Koopmans, J. (2010), «Être vu à table. Théâtralisations du repas et de la nourriture à la fin du Moyen Age», in N. Labère (coord.) Etre à table au Moyen Âge, Collection de la Casa de Velázquez (115), Madrid: 93-102.

Kózluk, M. (2012), "Se nourrir et se soigner: jardin et médecine pratique aux XVIe et XVIIe siècles”, Seizième Siècle, 8: 209-225.

Lamboley, J.(1995), Lexique d'Histoire et de Civilisation Romaines. Paris, Ellipses.

Langhans, F. (1942), As Antigas Corporações dos Ofícios Mecânicos e a Câmara de Lisboa, Lisboa, Câmara Municipal de Lisboa.

Langhans, F. (1943-1946), As Corporações dos Ofícios Mecânicos. Subsídios para a sua História, com um estudo de Marcelo Caetano, 2 vols, Lisboa, Imprensa Nacional de Lisboa.

Langhans, F. (1948), A Casa dos Vinte e Quatro. Subsidios para a sua História, Lisboa, Imprensa Nacional de Lisboa.

Laurioux, B. (1992), A Idade Média à Mesa, Lisboa, Europa-América.

Laurioux, B. (2001), “Cozinhas medievais (séculos XIV e XV)”, in J. L. Flandrin e M. Montanari (edits)., História da Alimentação, 2, Da Idade Média aos tempos actuais, trad. port., Lisboa, Terramar, 2001: 67-82.

Laurioux, B. (2002), Manger au Moyem Âge. Pratiques et discours alimentaires en Europe au $X I V^{e}$ et $X V^{e}$ siècles, Paris, Hachette.

Le Goff, J. (1992), "Saint Louis à table: entre commensalité royale et humilité alimentaire”, La Sociabilité à Table. Commensalité et Convivialité à Travers les Âges, Actes du Colloque de Rouen, 14-17 novembre 1990, Rouen, Publications de l' Université de Rouen : 133-144.

Le Goff, J. (1994, ed. port original fr. de 1964) A civilização do Ocidente Medieval, t. 1, 290-294.

Le Goff, J. Truong, G. (2003) Une Histoire du corps au moyen âge, Paris.

Le Goff, J., Chartier, R. e Revel, J. coords.(1978) La Nouvelle Histoire. Paris, Retz.

Lepelley, C. (1981), Les cités de l'Afrique Romaine au Bas Empire, t: 2: Notice d'histoire municipale. Paris, Études Augustiniennes.

Leveau, P. (2007), “The Western Provinces”, in W. Scheidel, I. Morris, R. Saller, (eds.), The Cambridge Economic History of the Greco-Roman World. Cambridge.

Lévi-Strauss, C. (1964-1968), Mythologiques 1 - Le Cru et le Cuit, 2 - Du Miel aux Cendres, 3 - L'Origine des Manières de Table, Paris, Plon.

Lévi-Strauss, C. (1968), “O triângulo culinário”, in Lévi-Strauss. São Paulo, Documentos, 24-35. 
Lévi-Strauss, C. (2003), Antropologia estrutural, Rio de Janeiro, Tempo Brasileiro.

Lévi-Strauss, C. (2005), Mitológicas 2: Do mel às cinzas. São Paulo, Cosac Naify.

Lévi-Strauss, C. (2006), Mitológicas 3: A origem dos modos à mesa. São Paulo, Cosac Naify.

Lévi-Strauss, C. (2010), Mitológicas 1: O cru e o cozido. 2. ed. São Paulo, Cosac Naify.

Lévi-Strauss, C. (2011), Mitológicas 4: O homem nu. São Paulo, Cosac Naify.

Lima, Carlos A. M.(2008), Artifices no Rio de Janeiro (1790-1808), Rio de Janeiro, Apicuri.

Ling, R. (1998), Ancient mosaics. London, British Museum Press.

Lisón Tolosana, C. (1991), La Imagen del Rey (Monarquia, Realeza y Poder Ritual en la Casa de los Austrias), Madrid, Espasa-Calpe.

Longo, O. (1998), “A alimentação dos outros”, in J. L. Flandrin, M. Montanari (dir.), História da alimentação. São Paulo, Estação Liberdade: 266-276.

Luccock, J. (1975), Notas sobre o Rio de Janeiro e partes meridionais do Brasil (1808-1818), $\mathrm{SP} / \mathrm{BH}$. Edusp/ Itatiaia.

Lurker, M. (1997), Dicionário de simbologia. São Paulo, Martins Fontes.

Lussana, A .(1952), "Munificenza nell'Africa Romana”, Epigraphica 14: 100-113.

Macedo, J. B. de (1982 2a ed.), Problemas de História da Indústria Portuguesa no século XVIII, Lisboa, Editorial Querco.

Macedo, L. P. de (1960), Lisboa de Lés a Lés. Subsídios para a História das Vias Públicas da Cidade, 2. ${ }^{a}$ edição, vol. 2, Lisboa, Câmara Municipal de Lisboa, .

Maciel, M. E. (2004), "Uma cozinha brasileira”, Estudos Históricos, Rio de Janeiro, 33: 25-39.

Madahíl, A. da R.(1943), "Pergaminhos do Arquivo Municipal de Coimbra”, Arquivo Coimbrão VII: 300-335.

Magalhães, J. R. (1987), “Em Busca dos 'Tempos’ da Inquisição (1573-1615)”, Revista de História das Ideias, 9, 2. ${ }^{\mathrm{a}}$ parte, Coimbra.

Magalhães, J. Romero e Salvado, J. P. (coords.) (2000), A Carta de Pêro Vaz de Caminha. Leitura paleográfica de E. Borges Nunes. Actualização ortográfica e notas de M. Viegas Guerreiro, Lisboa, Comissão Nacional para as Comemorações dos Descobrimentos Portugueses - Imprensa Nacional-Casa da Moeda.

Mahjoubi, A (1983), “O período romano e pós-romano na África do Norte”, in Gamal Mokhtar (ed.), História Geral da África, v. 2: A África Antiga. São Paulo - Paris, Ática - UNESCO, 473-509.

Maia, F. P. S. (1992), "O regime alimentar no Mosteiro de Bustelo entre os século XVII e XIX”, Poligrafia, 2: 173-196.

Maia, F. P. S. (1993), "À mesa com os Monges do Bustelo: algumas regras de conduta”, Humanistica e Teologia, Ano 14, Porto: 355-370.

Malakin, I., (ed.) (2009), Greek and Roman Networks in the Mediterranean. London.

Mamede, Z. (1970), Luís da Câmara Cascudo: 50 anos de vida intelectual, 1918-1968. Natal, Fundação José Augusto. 
Manger et Boire au Moyen Âge, Actes du Colloque de Nice (15-17 octobre 1982) (1984), Paris, Les Belles Lettres.

Manton, E. L. (1988), Roman North Africa. London, Seaby / B. T. Batsford.

Manuppella, G. (1986), O Livro de Cozinha da Infanta D. Maria Prólogo, Leitura, Notas aos Textos, Glossário e Índices, Lisboa, Imprensa Nacional-Casa da Moeda.

Manuppella, G. (1987), Livro de cozinha da Infanta D. Maria. Imprensa Nacional-Casa da Moeda, Lisboa.

Manuppella, G., Arnaut, S. D., (1967), Livro de cozinha da Infanta D. Maria de Portugal: primeira edição integral do Códice Português I. E. 33. da Biblioteca Nacional de Nápole, Coimbra, Por ordem da Universidade.

Maravall, J. A. (1983), "La idea de cuerpo mistico en España antes de Erasmo”, in Estudios de Historia del Pensamiento Español, I, Edad Media, 3a ed., Madrid, Ediciones Cultura Hispanica,179-199.

Marenco, C. (1992), Manières de Table, Modèles de Moeurs, 17e-20e siècle, Cachan, Editions de l'ENS.

Margolin,J.e Sauzet, R. (1982), Pratiques et discours alimentaires à la Renaissance, Actes du Colloque de Tours, 1977, Paris, Maisonneuve et Larose.

Marques, A. H. de O. (1980), «A Pragmática de 1340 », in Ensaios da História Medieval Portuguesa, 2a ed., Lisboa, Vega: 93-119.

Marques, A. H. de O. (2010, 6a ed.), A Sociedade Medieval Portuguesa. Aspectos da Vida Quotidiana, Lisboa, Esfera dos Livros.

Marques, A. H. de O. e Ferro, J. P. (1992), "L'alimentation au Portugal du Moyen Age au XVIIIe siècle”, in M. Aurell, O. Dumoulin et F. Thelamon (coords.) La Sociabilité à Table. Commensalité et Convivialité à Travers les Âges, Actes du Colloque de Rouen, 14-17 novembre 1990, Rouen, Publications de l'Université de Rouen.

Marques, E. S.; Cotta, R.a M. M; Priore, S. E. (2011), "Mitos e crenças sobre o aleitamento materno", Ciência Ẽ Saúde Coletiva 16(5):2461-2468.

Marques, J. (1993),"Filipe III de Espanha (II de Portugal) e a Inquisição Portuguesa face

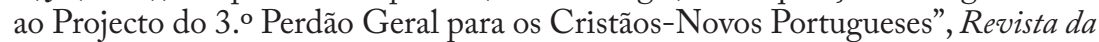
Faculdade de Letras. História, Porto, 2. ${ }^{\text {a }}$ série: vol. 10.

Marques, J. (1994), “O Arcebispo de Évora, D. Teotónio de Bragança, contra o Perdão Geral aos Cristãos-Novos Portugueses, em 1601-1602”, Congresso de História no IV Centenário do Seminário de Evora. Actas, vol. I, Évora, Instituto Superior de Teologia, Seminário Maior de Évora, 1994.

Marquilhas , R. (2000), A Faculdade das Letras. Leitura e Escrita em Portugal no século $X V I I$, Lisboa, Imprensa Nacional Casa da Moeda.

Marreiros, M. R. F. (1996), "Os proventos da terra e do mar”, in M. H.da C. Coelho e Ar. L. de C. Homem (coord.), Portugal em definição de fronteiras (1096-1325): Do Condado Portucalense à crise do século XIV, in J. Serrão e A. H. de Oliveira Marques (dir.), Nova História de Portugal, vol. III, Lisboa, Presença.

Martins . M. de S. N. (2008), Entre a Cruz e o Capital. As Corporações de Ofícios no Rio de Janeiro após a Chegada da Família Real 1808-1824, Rio de Janeiro, Garamond, 
Martins, A. A. (2003), O Mosteiro de Santa Cruz de Coimbra na Idade Média, Lisboa, Centro de História da Universidade.

Martins, M., (2011), Poder e sociedade : a duquesa de Beja, Tese de Doutoramento apresentada à Faculdade de Letras da Universidade de Lisboa;

Martins, R. (1993), “A alimentação medieval: práticas e representações”, Revista de Ciências Históricas, Univ. Portucalense, VII: 67-82.

Martius, C.F. P. (1845), "Como se deve escreve a História do Brasil”, Revista do IHGB, 6, 24: 381-403.

Matias, A. L. B. P. M. (1999) O Porto em 1533 - Actas de vereações da cidade, Tese de Mestrado apresentada à Faculdade de Letras da Universidade do Porto.

Matos, J.da C- (1998), A Colegiada de São Cristóvão de Coimbra (sécs. XII e XIII), Tomar.

Mattingly, D. J. (1988), “The olive boom: olive surpluses, wealth and power Tripolitania”, Libyan Studies, 19: 21-41.

Mattingly, D. J. (1996), "First fruit? The olive in the Roman World", in G. Shipley, J. Salmon (eds.), Human landscapes in Classical Antiquity: environment and culture. London-New York, Routledge, 213-253.

Mattingly, D. J. (ed.) (1993), Dialogues in Roman Imperialism; power, discourse and discrepant experience in the Roman Empire (Journal of Roman Archaeology, supp. 23).

Mattingly, D. J., Hitchner, R. B. (1993), “Technical specifications for some problems North Africa olive presses of Roman date", in M.-C. Amouretti, J.-P. Brun (eds.), La production du vin et de buile en Méditerranée (Bulletin de Correspondance Hellénique, supp. 26), 439-462.

Mattingly, D. J., Hitchner, R. B. (1995), “Roman Africa: an archaeological review”, Journal of Roman Studies, 85: 165-213.

Mattoso, J. (2007), D. Afonso Henriques, Lisboa, Temas e Debates.

Mazzini, I. (1998), “A alimentação e a medicina no mundo antigo”, J. L. Flandrin, M. Montanari (dir.), História da alimentação. São Paulo, Estação Liberdade: 254-265.

Mega, J. F.; Neves, E.; Andrade, C. J. (2011), “A produção da cerveja no Brasil”, Rev Citino 1(1):34-42.

Melo, A. R.A. de S. (2009), Trabalho e Produção em Portugal na Idade Média: o Porto, c. 1320 c. 1425, Dissertação de Doutoramento apresentada à Fauldade de Letras da Universidade do Minho. (http://repositorium.sdum.uminho.pt/bitstream/1822/9896/2/ PhD_Arnaldo\%20Sousa\%20Melo_volume\%20I.pdf, consultado em 2013.10.25)

Menjot, D. (coord) (1984), Manger et Boire au Moyen Âge : Actes du Colloque de Nice. Les Belles Lettres, Paris.

Migne, J.P. s/d, Martinho de Braga, De Ira; Pro Repellenda Iactantia; De Superbia; Exhortatio Humilitatis. Formula Vitae Honestae, Patrologia Latina, vol. 172, cols 1109-1176, PL 72, cols 31-46.

Migne, J.P. s/d, Patrologia Latina, vol. 172, cols 1109-1176.

Miranda, M. A., Sousa, L.C. de (2011), “A 'mesa do rei' como metáfora do poder”, in A. I. Buesco, D. Felismino (coords.), A Mesa dos Reis de Portugal, Lisboa, Temas e Debates - Círculo de Leitores, 383- 405. 
Moatti, C. (2004), La mobilité des personnes en Méditerranée, de l'Antiquité à l'époque: procédures de contrôle et documents d'identification. Rome, École Française de Rome.

Moatti, C. (2008), Mobility and controls in the Roman World. Victoria, University of Victoria.

Moatti, C., Kaiser, C. (2009), Gens de passage en Méditerranée, de L'Antiquité à l'époque moderne. Paris, Maisonneuve et Larose.

Montanari, M. e Ilaria, P.(2012) «Entre le ventre et la gueule, dans la culture médiévale », in K. Karila-Cohen, F. Quelier (coord), Le corps du Gourmand, D'Héraclès à Alexandre le Bien Heureux, PUFR, 37-55.

Montanari, M. (1985), L'Alimentazione contadina nell'alto Medioevo, Napoli, Liguore.

Montanari, M. (1992 2a ed.), Alimentazione e cultura nel Medioevo, Roma, Laterza.

Montanari, M. (1995), La faim et l'abondance. Histoire de l'alimentation en Europe, Paris, Seuil.

Monteiro, J. C. dos S.; Nakano, A. M.; Gomes, F. A. (2011), “O aleitamento materno enquanto uma prática construída. Reflexões acerca da evolução histórica da amamentação e desmame precoce no Brasil”, Invest Educ Enferm 29(2): 315-321.

Montero, P. (2006), "Índios e missionários no Brasil: para uma teoria da mediação cultural”, in P. Montero (org.), Deus na Aldeia: missionários, indios e mediação cultural, São Paulo, Globo.

Moreno Valero, M. (1989), "Religiosidad Popular en Córdoba en el siglo XVIII”, in C. Álvarez Santaló, María J, Buxó e S. Rodriguez Becerra (coord.) La Religiosidad Popular, vol. 3 (Hermandades, Romerias y Santuarios), Barcelona, Anthropos.

Moreno, H. B. (1988), Os Itinerários de el-Rei Dom João I (1384-1433), Lisboa, Instituto de Cultura e Língua Portuguesa.

Morris, I. (2005), “Mediterraneisation”, in I. Mahlkin (ed.), Mediterranean paradigms and Classical Antiquity. London-New York, Routledge.

Morujão, M. do R. B. (2010), A Sé de Coimbra: a instituição e a chancelaria (1080-1318), Lisboa, Fundação Calouste Gulbenkian e Fundação para a Ciência e Tecnologia.

Mota, S. M. (1990), “O Regime Alimentar dos Monges Bernardos no Final do Século XVIII”, Revista de Ciências Históricas, Universidade Portucalense, V: 271-290.

Mott, Luís (2001), "Meu Menino Lindo: Cartas de Amor de um Frade Sodomita, Lisboa (1690)”, Luso-Brazilian Review, n. ${ }^{\circ} 38$, Madison, 97-115.

Mott, Luís (2005), "In Vino Veritas: Vinho e Aguardente no Quotidiano dos Sodomitas Luso-Brasileiros à Época da Inquisição”, in R. P. Venâncio e H. Carneiro (org.) Álcool e Drogas na História do Brasil, São Paulo, Alameda, Belo Horizonte, Pontifícia Universidade Católica de Minas Gerais, 47-70.

Nakano, A. M. S.; Beleza, A. C.; Gomes, F. A.; Mamede, F. V. (2003), "Cuidado no "resguardo": as vivências de crenças e tabus por um grupo de puérpera", Rev Bras Enfermagem 56(3):242-247.

Neto, M. C. N. (1999) "Vivência Lisboeta”, Negros em Portugal- sécs. XV-XIX, Lisboa, Comissão Nacional para as Comemorações dos Descobrimentos Portugueses.

Neto, M. L. A. C. M. C. S. (1959), A Freguesia de Santa Catarina de Lisboa no 1. o quartel 
do século XVIII (Ensaio de Demografia Histórica), Lisboa, Centro de Estudos Demográficos.

Neto, M. S. (1997), "A Persistência Senhorial”, in J.Mattoso dir., História de Portugal, vol. 3, No Alvorecer da Modernidade. 1480-1620, Lisboa, Estampa: 165-175.

Neves, C. M. L. B., (1980), [HFCA] História Florestal, Aquicola e Cinegética. Colectânea de Documentos existentes no Arquivo Nacional da Torre do Tombo. Chancelarias Reais, vol. I (1208-1430), Lisboa, Ministério da Agricultura e Pescas - Direcção Geral do Ordenamento do Território.

Newhauser R., (1993) The Treatise on Vices and virtues in Latin and the Vernacular, Typologie des sources du moyen age occidental 68, Brepols.

Nunes, N. (2003), O açúcar de cana na ilha da Madeira: do Mediterrâneo ao Atlântico. Terminologia e tecnologias históricas e actuais da cultura açucareira, Dissertação de Doutoramento apresentada à Universidade da Madeira, (http://digituma.uma. pt/handle/10400.13/318, consultada em 7 de Agosto de 2013).

Odália, N. (1997), As Formas do Mesmo - ensaios sobre o pensamento historiográfico de Varnhagen e Oliveira Vianna. São Paulo, Editora da Unesp.

Oliveira, A. de (1971), A Vida Económica e Social de Coimbra de 1537 a 1640, Coimbra, Faculdade de Letras e Instituto de Estudos Históricos Dr. António de Vasconcelos.

Oliveira, A. de (2010), “O Motim de 1605”, Pedaços de História Local, vol. 1, Coimbra, Palimage, 217-227.

Oliveira, C. R. de (1987), Lisboa em 1551. Sumário, organização e notas de José da Felicidade Alves, Lisboa, Livros Horizonte, 97-100.

Oliveira, E. F. de (1906), Elementos para a História do Município de Lisboa, vol. 15, Lisboa, Tipografia Universal, 373-379.

Olson, S. D. and Sens, A. (2000), Archestratos of Gela. Greek Culture and Cuisine in the Fourth Century BCE. Oxford.

Opitz, C. (1990), “O quotidiano da mulher no final da Idade Média (1250-1500)”, in C. Klapisch-Zuber, História das mulheres - a Idade Média, Porto, Afrontamento.

Ornellas, L. H. (1978) A alimentação através dos tempos. Rio de Janeiro, FENAME, 9-49.

Paiva, J. P. (2011), Baluartes da Fé e da Disciplina. O Enlace entre a Inquisição e os Bispos em Portugal (1536-1750), Coimbra, Imprensa da Universidade.

Paiva,J.P. (coord.) (2002), Portugaliae Monumenta Misericordiarum, v. 2, Antes da fundação das Misericórdias, Lisboa, União das Misericórdias Portuguesas.

Palla, M.J. (1996), "Manger et boire au Portugal à la fin du Moyen Age - texte et image”, Banquets et Manières de Table au Moyen Age, Aix-en-Provence, CUER-MA.

Palla, M. J. (1998), “Cozinhar é contar uma história. O imaginário alimentar em Gil Vicente”, Actas do Quinto Congresso da Associação Internacional de Lusitanistas, Oxford - Coimbra.

Palla, M. J. (trad.) (2008), Livre de Cuisine de l'Infante Maria du Portugal femme d'Alexandre Farnèse, Lisboa, IEM/FCSH.

Panella, C. (1986), "Le anfore tardoantiche: centri di produzione e mercati preferenziali”, 
in Andrea Giardina, ed., Società romana e impero tardoantico, III. Roma-Bari, Editori Laterza, 251-284.

Panella, C. (1993), "Merci e scambi nel Mediterraneo tardoantico”, in Andrea Giardina, L. Cracco Ruggini, A,. Carandini, eds., Storia di Roma, III.2. Roma, 613-697.

Panella, C., Tchernia, A. (1994), "Produits agricoles transportés en amphores: l'huile et surtout le vin”, in L'Italie d'Auguste à Diocletien. Rome, École Française de Rome, 145-165.

Paoli, U. E. (1956 2a ed.), Urbs; la vida en la Roma antigua. Barcelona, Iberica, 117-137.

Patridge, B. (2004), Uma história das orgias. São Paulo, Planeta do Brasil.

Patrone, A. M. N. (1981), Il cibo del rico ed il cibo del povero. Contributo alla storia qualitativa dell'alimentazione. L'area pedemontana negli ultimi secoli del Medio Evo, Turín, Centro Studi Piemontesi.

Peacock, D. P. S., Benjaoui, F., Belazreg, N. (1989), “Roman amphora: production in the Sahel region of Tunisia”, Amphores: 179-222.

Peacock, D. P. S., Benjaoui, F., Belazreg, N. (1990), “Roman pottery production in central Tunisia”, Journal of Roman Archaeology 3: 59-84.

Pereira ,E. (1979), Subsídios para a História da Indústria Portuguesa. Com um Ensaio sobre as Corporações e Mesteres por Carlos da Fonseca, Lisboa, Guimarães Editores.

Pereira , F. (2008), Ofícios do Couro na Lisboa Medieval, Lisboa, Prefácio.

Pereira, A. M. (2000), A Mesa Real. Dinastia de Bragança, Lisboa, Inapa.

Pereira, A. M. (2011), "Ofícios de boca' na Casa Real Portuguesa (Séculos XVII e XVIII), in A. I. Buescu e D. Felismino (coords.), A Mesa dos Reis de Portugal, Lisboa, Temas e Debates - Círculo de Leitores.

Pereira, F. J., COSTA, José Pereira da, (1985), Livros de contas da Ilha da Madeira : 15041537, Vol. I Rendas e Almoxarifados, Coimbra;

Perlès, C. (1989), "Fogo", in R. Romano (dir.), Enciclopédia Einaudi, v. 16: HomoDomesticação-Cultura Material. Lisboa, Imprensa Nacional - Casa da Moeda.

Pessanha, J. da S. (1914), Inventário da Infanta D. Beatriz - 1507”, Archivo Historico Portuguez, Lisboa, Vol. IX: 64-110.

Picard, G. C. (1990), La civilisation de l'Afrique Romaine. 2. ed. Paris, Études Augustiniennes.

Pilcher, J., (ed.) (2012), The Oxford Handbook of Food History. Oxford, University Press.

Pimentel, A. F. (2003), A Morada da Sabedoria. O paço real de Coimbra das origens ao estabelecimento da Universidade. Coimbra, Faculdade de Letras.

Pimentel, M. C. et alii (2004), Marcial. Epigramas. Vol. IV. Introd. e notas de M. C. Pimentel; trad. D. F. Leão, P. S. Ferreira, J. L. Brandão. Edições 70, Lisboa.

Silva, P. P. (2005), Farinha, feijão e carne seca, um tripé culinário no Brasil colonial. São Paulo, Senac.

Piponnier, F. (2001), "Do lume à mesa: Arqueologia do equipamento alimentar no fim da Idade Média”, in J. L. Flandrin e M. Montanari (dirs.), História da Alimentação, 2, Da Idade Média aos tempos actuais, trad. port., Lisboa, Terramar, 2001: 123-132. 
Plasencia, P. (2005), A la mesa con don Quijote y Sancho, Barcelona, Puncto de lectura.

Pontique , É. le, (1971) Traité Pratique ou le Moine, 2 vols, A. Guillaumont , C. Guillaumont ed. e trad., SC 170-171, le Cerf.

Prado Junior, C. (1972), Formação do Brasil Contemporâneo. São Paulo, Cia. das Letras.

Priore, M. D. (1997), "Magia e medicina na colônia: o corpo feminino", in M. Priore, História das mulheres no Brasil, São Paulo, Contexto.

Raminelli, R. (1997), “Eva Tupinambá”, in M. Priore, História das mulheres no Brasil, São Paulo, Contexto.

Randsborg, K. (1991), The millennium AD in Europe and Mediterranean; an archaeological essay. Cambridge, University Press.

Rau, V. (1984), Estudos sobre a história do sal português, Lisboa, Editorial Presença.

Raven, S. (1984), Rome in Africa. 2. ed. London - New York, Longman.

Rego, M. (coord.) (2a. ed. 1998), Livros Portugueses de Cozinha, Lisboa, Biblioteca Nacional.

Rego,M. (1998, 2aed.) Livros Portugueses de Cozinha., Lisboa, Biblioteca Nacional.

Reis, J. P. L., Algumas notas para a bistória da alimentação em Portugal, Lisboa, Campo das Letras.

Reis, M. de F. (2007), "A Confraria da Avé-Maria do Convento de São Bento de Santarém: Afirmação e Prestígio dos Estatutos de Limpeza de Sangue”, in L. F. Barreto et alli (coord.) Inquisição Portuguesa. Tempo, Razão e Circunstância, Lisboa, São Paulo, Prefácio.

Remesal, J. (1977/1978), Economía oleícola bética: nuevas formas de análisis, Archivo Español de Arqueología 51: 87-142.

Remesal, J. (1981), "Reflejos económicos y sociales en la producción de ánforas olearias béticas (Dressel 20)”, ICAA. Madrid, Universidad Complutense: 131-153.

Remesal, J. (1983), “Transformaciones en la exportación del aceite bético mediados del siglo III d.C., II CAA. Madrid, Universidad Complutense: 115-129.

Remesal, J. (1986), La annonna militaris y la exportación del aceite bético a Germania. Madrid, Universidad Complutense.

Remesal, J. (1989), “Tres nuevos centros productores de ánforas Dressel 20 y 23. Los sellos de Lucius Fabius Cilo", Ariadna 6: 121-153.

Rich, A. (2008), Dictionnaires des Antiquités Romaines et Grecques. Singapour, Molière.

Richter, G. M. A., Milne, M. J. (1935), Shapes and Names of Athenian Vases. Metropolitan Museum of Art. New York.

Ritchie, C. I. A. (1995), Comida e civilização; de como a história foi influenciada pelos gostos bumanos. Lisboa, Assírio \& Alvim.

Robert, J. (1995), “Os prazeres da mesa”, in J. N. Robert, Os prazeres em Roma. São Paulo, Martins Fontes, 121-152.

Rocha Pereira, M. H. (1992), Eurípides, As Bacantes. Introdução, tradução do grego e notas. Lisboa. Edições 70.

Rocha, R. (1998), A Viagem dos Sabores. Ensaio sobre a História da Alimentação (séculos 
$I X-X I X)$ seguido de 100 Receitas em que vários mundos se encontram, Lisboa, Inapa. Rodrigues Moñino, A., (1956), Viaje a España del Rey Don Sebastian de Portugal, Editora Castalia, Valencia.

Rodrigues, A. M. S. A. (2011), "A mesa, o leito, a arca, a mula. Como se provia ao sustento e itinerância das rainhas de Portugal na Idade Média”, in A. I. Buescu e D. Felismino (coords.), A Mesa dos Reis de Portugal, Lisboa, Temas e Debates Círculo de Leitores, 44-63.

Rodríguez-Almeida, E. (1972), “Novedades de epigrafía anforaria del Monte Testaccio”, Recherches sur les amphores romaines. Rome, École Française de Rome, 107-211.

Rodríguez-Almeida, E. (1979), "Monte Testaccio: i mercatores dell'olio della Betica”, Mélanges de l'École Française de Rome 91: 874-975.

Rodríguez-Almeida, E. (1984a), "E1 emporio fluvial y el Testaccio: onomástica extraanforica y otros problemas”, II CAA. Madrid, Universidad Complutense, 133161.

Rodríguez-Almeida, E. (1984b), Il Monte Testaccio. Roma, Quasar.

Romagnoli, D. (1991), “Cortesia nella città: un modello complesso. Note sull'etica medievale delle buone maniere", in D. Romagnoli (coord.) La Città e la Corte. Buone e Cattive Maniere tra Medioevo ed Età Moderna, con un saggio introduttivo di Jacques Le Goff, Milão, Ed. Angelo Guerini : 47-48 e pp.59-61 (trad. francesa, com alterações, La Ville et la Cour. Des bonnes et des mauvaises manières Paris, Fayard, 1995)

Romagnoli, D. (2001), « Guarda no sii Vilan : as Boas Maneiras à Mesa », in J. L.Flandrin e M. Montanari (dirs)., História da Alimentação, 2, Da Idade Média aos tempos actuais, trad. port., Lisboa, Terramar: 111-121.

Romani, M. A. (1997), “Regalis coena: aspetti economici e sociali del pasto principesco (Italia settentrionale secoli XVI-XIX)”, in S. Cavaciocchi (dir.) Alimentazione e Nutrizione secc. XIII-XVIII. Atti della "Ventottesima Settimana di Studi" do Istituto Internazionale di Storia Económica "F. Datini”- Prato, 22-27 aprile 1996, Florença, Le Monnier, 719-740.

Rosellini, M. et Saïd, S. (1978), “Usages des femmes et autres nomoi chez les 'sauvages' d'Hérodote: essai de lecture structurale”, Annali della Scuola Normale Superiore di Pisa 8. 3: 949-1005.

Rossa, W. (2001), DiverCidade. Urbanografia do espaço de Coimbra até ao estabelecimento definitivo da Universidade, Coimbra, Faculdade de Ciências e Tecnologia.

Rousselle, A. (1990), “A política dos corpos: entre procriação e continência em Roma”, in P. S. Pantel, História das mulheres - a Antiguidade, Porto, Afrontamento.

Rowlands, M. et alii (eds.) (1987), Centre and periphery in the Ancient World. Cambridge: CUP.

Sá, I. G. (2004), “O Trabalho”, História Económica de Portugal 1700-2000, organização de Pedro Lains e Álvaro Ferreira da Silva, Lisboa, Instituto de Ciências Sociais, 96.

Salvador, F. V. (1982), História do Brasil: 1500-1629, São Paulo Ed USP.

Salviat, F. (1986), “Le vin de Thasos. Amphores, vin et sources écrites”, J.-Y. Empereur, 
Y. Garlaand (eds.), Recherches sur les amphores grecques. Suppléments au Bulletin de Correspondance Helléniques 13: 145-196.

Sandre-Pereira, G.; Colares, L. G. T. ; Carmo, M. das G. T. do; Soares, E. de A.(2000), "Conhecimentos maternos sobre amamentação entre puérperas inscritas em programa de pré-natal”, Cad. Saúde Pública 16(2):457-466.

Santana, F. (1988), “Lisboa 1800 - A Freguesia do Socorro", Lisboa. Revista Municipal, 2. ${ }^{\mathrm{a}}$ série, n. ${ }^{\circ} 24$, Lisboa.

Santana, F. (1999), "Lisboa - 1800. Anjos e Arroios”, Boletim Cultural da Assembleia Distrital de Lisboa, Lisboa, IV série, n. ${ }^{\circ}$ 93, tomo 2.

Santana, F. (2000), “Lisboa 1800 - São Julião”, Arqueologia e História, Lisboa, vol. 52.

Santana, F. (s/d), Lisboa na segunda metade do século XVIII. Plantas e Descrições das suas Freguesias, recolha e índices por Francisco Santana, Lisboa, Câmara Municipal de Lisboa.

Santos , B. C. C. (2005a), O Corpo de Deus na América. A Festa de Corpus Christi nas Cidades da América Portuguesa - século XVIII, São Paulo, Annablume, 85-92;

Santos , B. C. C. (2012), “Os Senhores do Tempo: a Intervenção do Bispado na Procissão de Corpus Christi no século XVIII”, Tempo, 33: 165-190.

Santos, M. J. A. (1983), "O peixe e a fruta na alimentação da Corte de D. Afonso V: breves notas", Brigantia, III, 3: 307-343.

Santos, M. J. A. (1992), O mais antigo livro de cozinha português: receitas e sabores, sep. da Revista Portuguesa de História, XXVII.

Santos, M. J. A. (1997), A Alimentação em Portugal na Idade Média. Fontes. Cultura. Sociedade, Coimbra, Tipografia Lousanense.

Santos, M. J. A. (2002), Jantar e Cear na Corte de D. João III. Leitura, Transcrição e Estudo de Dois Livros da Cozinha do Rei (1524 e 1532), Vila do Conde - Coimbra, Câmara Municipal de Vila do Conde, Centro de História da Sociedade e da Cultura.

Santos, M.J.A. (2005b), “A escrita serve à mesa. Um valioso livro da ucharia da casa d'E1 Rei D. João III”, Actas do VI Congresso Galiza - Norte de Portugal, Chaves: 23-65.

Santos, M. J. A. (2006), "O Azeite e a Vida do Homem Medieval”, in Estudos em Homenagem ao Prof. Doutor José Amadeu Coelho Dias, vol. II, Porto, Faculdade de Letras: 139-157.

Santos, N. P., Gama, A. (2011), “As tradições do pão, território e desenvolvimento”, in N. Santos, L. Cunha (coords.), Trunfos de uma Geografia Activa. Desenvolvimento local, ambiente, ordenamento e tecnologia. Imprensa da Universidade de Coimbra, Coimbra: 273-282

Saraiva, J. da C., (1931), “Um jantar do século XVII”, in Feira da Ladra, n. 1.

Saraiva, J. H. (1997), Ditos Portugueses Dignos de Memória. História Íntima do século XVI, $3^{\text {a }}$ ed., Lisboa, Europa-América.

Saramago, A. (2000), Doçaria Conventual do Alentejo as receitas e o seu enquadramento bistórico. Sintra, Colares Editora.

Saramago, A. e Cardoso, A. H. (2000), Para a História da Doçaria Conventual Portuguesa, 


\section{Lisboa, CTT.}

Sassatelli, G. (1998), “A alimentação dos etruscos”, in J. L. Flandrin, M. Montanari, dir., História da alimentação. São Paulo, Estação Liberdade, 186-198.

Scheidel, W., Reden, S., eds. (2002), The ancient economy. London-New York, Routledge.

Schwarcz, L. M. (1989), Os guardiões da nossa história oficial: os institutos históricos e geográficos brasileiros. São Paulo, IDESP, Instituto de Estudos Econômicos, Sociais e Políticos.

Serafim, J. C. G. (2011), Um Diálogo Epistolar. D. Vicente Nogueira e o Marquês de Niza, Porto, CITCEM e Edições Afrontamento.

Serrão, Vítor (1983), O Maneirismo e o Estatuto Social dos Pintores Portugueses, Lisboa, Imprensa Nacional Casa da Moeda.

Shaw, B. D. (1982/83), "Eaters of flesh, drinkers of milk: the ancient Mediterranean ideology of the pastoral nomad", Ancient Society 13/14: 5-31.

Shaw, B. D. (1984), "Water and society in the ancient Maghreb: technology, property and development”, Antiquités Africaines 20: 121-173.

Shaw, B. D.. (2001), "Challenging Braudel: a new vision of the Mediterranean”, Journal of Roman Archaeology, 14: 419-453.

Sherratt, S. (Apr.-Jun. 2004), "Feasting in Homer”, Hesperia 73. 2: 301-337.

Silva, A. A. M. (1990), Amamentação: fardo ou desejo? Estudo histórico-social dos saberes e práticas sobre aleitamento na sociedade brasileira. Dissertação de mestrado. Faculdade de Medicina de Ribeirão Preto da Universidade de São Paulo, Ribeirão Preto.

Silva, F. R. (2008) Quinhentos /Oitocentos (Ensaios de História), Porto, Faculdade de Letras da Universidade do Porto.

Silva, I. A. (1996), "Reflexões sobre a prática do aleitamento materno", Rev Esc Enf USP 30(1): 58-72.

Silva, J. B. de A. e. (1998). Projetos para o Brasil. São Paulo, Cia. das Letras.

Silva, J. C. V. da (2010), “O Paço”, in B. Vasconcelos e Sousa (coord.), A Idade Média, in J. Mattoso (dir.), História da Vida Privada em Portugal, Temas e Debates - Círculo de Leitores, 78-97.

Silva, M. H. (2011), Pretas de Honra. Vida e Trabalho de Domésticas e Vendedoras no Recife do século XIX (1840-1870), Recife, Editora Universitária da UFPE, Salvador, EDUFBA,

Silva, M. S. (2012), A rainha inglesa de Portugal. Filipa de Lencastre, Lisboa, Círculo de Leitores.

Silva, M., org. (2003), Dicionário Crítico Câmara Cascudo. São Paulo, Perspectiva.

Simon Palmer, M. del C. (1990), "El cuidado del cuerpo de las personas reales: de los médicos a los cocineros en el real alcázar”, Le Corps dans la Société Espagnole des XVIe et XVIIe siècles. Colloque International (Sorbonne, 5-8 octobre 1988), Études réunies et présentées par Augustin Redondo, Paris, Publications de La Sorbonne, 113-122.

Sissa, G. (1990), "Filosofias do género: Platão, Aristóteles e a diferença dos sexos”, in P. S. Pantel, História das mulheres - a Antiguidade, Porto, Afrontamento. 
Slim, H. (1996), "Spectacles", in Michèle Blanchard-Lemée et alii, Mosaics of Roman Africa; floor mosaics from Tunisia. London, British Museum Press, 188-217.

Soares, C. (2005), “A visão do “outro” em Heródoto”, in M. C. Fialho, M. F. Silva, M. H. Rocha Pereira (eds.), Génese e consolidação da ideia de Europa. Vol. I: de Homero ao fim da época clássica. Imprensa da Universidade de Coimbra, 95-176.

Soares, C. (2009a), Ciclope. Introdução, tradução do grego e notas, in Eurípides. Tragédias I. Introdução geral de Maria de Fátima Sousa e Silva. Imprensa Nacional-Casa da Moeda. Lisboa, 23-108.

Soares, C. (2009b), "Bons selvagens e monstros malditos em Heródoto e Eurípides”, in Maria de Fátima Silva (ed.), Utopias E̋ Distopias. Imprensa da Universidade de Coimbra, 57-63.

Soares, C. (2012), "Receitas do mais antigo Guia Gastronómico: Iguarias do Mundo de Arquéstrato”, in M. R. Cândido, (org.), Práticas Alimentares no Mediterrâneo Antigo. NEA-UERJ. Rio de Janeiro, 33-59.

Soares, C. (2013), "Matrizes clássicas gregas da História da Dieta: contributos da tratadística hipocrática”, in C. Soares (coord.), Espaços do Pensamento Científico da Antiguidade. Ciclo de Conferências \& Debates Interdisciplinares I. Coimbra, Imprensa da Universidade de Coimbra,13-36.

Sousa, D. F. F. de (2013), Arte Doceira de Coimbra. Conventos e Tradições. Receituários (XVII-XX), Coimbra, Colares Editora.

Sousa, G. de V.e (2012), "Uma Loja de Tecidos em Ponta Delgada nos Finais do Século XVIII”, Matrizes da Investigação em Artes Decorativas III, direcção de Gonçalo de Vasconcelos e Sousa, Universidade Católica do Porto, CITAR, 11-40.

Standage, T. (2005). A bistória do mundo em 6 copos. Jorge Zahar.

Stefanello, J., Nakano, A. M. S., Gomes, F. A. (2008), "Beliefs and taboos related to the care after delivery: their meaning for a women group". Acta paul. Enferm, São Paulo 21(2):275-281.

Stefanello, J.; Nakano, A. M. S.; Gomes, F. A. (2008), "Beliefs and taboos related to the care after delivery: their meaning for a women group". Acta paul. Enferm, São Paulo 21(2):275-281.

Stouff, L. (1970), Ravitaillement et alimentation en Provence au XVe siècle, Paris/La Haye, Mouton.

Strong, R. (2002), Feast: a History of Grand Eating, Londres, J. Cape.

Strong, R. (2004), Banquete, uma bistória da culinária, dos costumes e da fartura à mesa. Rio de Janeiro, Jorge Zahar.

Tavares, P. M. (1980), “Iguarias e manjares do século XVII”, História, 21 (Julho): 36-42.

Tavares, P. M. (1999), Mesa, Doces e Amores no século XVII português, Sintra, Colares Editora.

Thébert, Y. (1990), "Vida privada e arquitetura doméstica na África Romana", in P. Veyne (org.), Do Império Romano ao ano mil , in P. Ariès, G. Duby (orgs.), História da vida privada, v. 1, São Paulo, Companhia das Letras, 300-398.

Thivel, A. (2000), "L'évolution du sens de AIAITA”, in J. A. López Férez (ed.), La lengua cientifica griega. Madrid: 25-37. 
Thomas, R. (2000), Herodotus in Context: Etnography, Science and the art of Persuasasion. Cambridge University Press.

Thomas, R. (2006), “The Intellectual Milieu of Herodotus”, in C. Dewald and J. Marincola (eds.), The Cambridge Companion to Herodotus. Cambridge University Press, 60-75.

Toma, T. S. (2011), "Aleitamento materno e políticas públicas: implicações para a saúde na infância e na vida adulta”, in J. A. Taddei, , R. M. F. Lang, G. Longo-Silva e M. H. de A. Toloni, Nutrição em saúde pública, Rio de Janeiro, Rubio.

Torres, J. V. (1994) “Da Repressão Religiosa para a Promoção Social. A Inquisição como instância legitimadora da promoção social da burguesia mercantil”, Revista Crítica de Ciências Sociais, 40: 109-135.

Toussaint-Samat, M., (1997), Histoire Naturelle et Moral de la Nourriture, Paris, Larousse.

Trindade, L. (2002), A Casa Corrente em Coimbra. Dos finais da Idade Média aos inícios da Época Moderna, Coimbra, Câmara Municipal.

Trindade, L. (2009), Urbanismo na composição de Portugal, Dissertação de Mestrado apresentada à Faculdade de Letras da Universidade de Coimbra.

Trindade, M. J. L. e Gaspar, J. (1973/1974), “A utilização agrária do solo em torno de Lisboa, na Idade Média, e a teoria de von Thünen”. Boletim Cultural da Junta Distrital de Lisboa II/LXXIX-LXXX: 3-11.

Trindade, R. A. (2010), Cerâmica medieval, século XII a meados do século XVI, tese de Doutoramento apresentada à Faculdade de Letras da Universidade Nova de Lisboa, Lisboa.

Trombetta, S. (2005), "O momento festivo e a eternidade: a perpetuação da memória nos mosaicos de banquete”, in R. M. da C. Bustamante, F. de S. Lessa (orgs.), Memória e festa. Rio de Janeiro, Mauad, 141-146.

Valeri, R. (1989a), “Alimentação”, in R. Romano (dir.), Enciclopédia Einaudi, v. 16: HomoDomesticação-Cultura Material. Lisboa, Imprensa Nacional - Casa da Moeda: 191-209.

Valeri, R. (1989b), "Fome”, in in R. Romano (dir.), Enciclopédia Einaudi, v. 16: HomoDomesticação-Cultura Material. Lisboa, Imprensa Nacional - Casa da Moeda: 169-190.

Varandas, C.P. R. (1999), A Colegiada de S. Pedro de Coimbra das Origens ao Fim do Século $X I V$. Estudo Económico e Social, Coimbra, Faculdade de Letras.

Vasconcelos, J. L. de (1893), As raças humanas e a civilização primitiva, 2a ed., Lisboa, António Maria Pereira.

Vasconcelos, J. L. de (1983-88), Etnografia Portuguesa, 8 vols., Lisboa, Imprensa Nacional-Casa da Moeda.

Vasselin, M. (1999), "Des fastes de Bacchus aux beuveries flamandes : l'iconographie du vin de la fin du XVe siècle à la fin du XVIIe siècle ", Nouvelle Revue du XVIe Siècle, $17 / 2: 219-251$.

Veiga, T. P. (2009) Fastigimia, Lisboa, INCM.

Veloso, C. (1992), A Alimentação em Portugal no Século XVIII nos Relatos de Viajantes Estrangeiros, Coimbra, Minerva. 
Venâncio, R. P. (1997), "Maternidade negada”, in M. Priore, História das mulheres no Brasil, São Paulo, Contexto.

Ventura, L. (2002), “Coimbra Medieval. 1. A gramática do território”, Economia, Sociedade e Poderes. Estudos em homenagem a Salvador Dias Arnaut, Coimbra, Ausência: 23-40.

Ventura,L.(2003), “Coimbra Medieval: uma cidade em formação”, in A.Alarcão (coord.), Coleç̧ão de ourivesaria medieval, séculos XII-XV, Lisboa, Instituto Português de Museus.

Ventura, L. (2006a), “As Cortes ou a instalação em Coimbra dos fideles de D. Sesnando”, Estudos em Homenagem ao Professor Doutor José Marques, vol. III, Porto, Faculdade de Letras, 37-52.

Ventura, L. (2006b), D. Afonso III, Lisboa, Círculo de Leitores.

Verdier, Y. V (1978)., Façons de dire, façons de faire. La laveuse, la couturière, la cuisinière. Paris, Gallimard.

Verdon, J. (2002), Boire au Moyen Âge, Paris, Perrin.

Vernant, J., Detienne, M. (1990 2a ed.), La cuisine du sacrifice en pays grec, Paris, Gallimard.

Veyne, P. (1976), Le pain et le cirque; sociologie historique d'un pluralisme politique. Paris, Seuil.

Veyne, P. (1990), "Prazeres e excessos", in P. Veyne (org.), Do Império Romano ao ano mil, in P. Ariès, G. Duby (orgs.), História da vida privada, v. 1, São Paulo, Companhia das Letras, 178-199.

Vidal-Naquet, P. (1995 4a ed.), "Os jovens: o cru, a criança grega e o cozido”, in J. Le Goff, P. Nora (orgs.), História: novos objetos, Rio de Janeiro, Francisco Alves: 116-140.

Vigarello, G. (2005), "Le corps du roi”, in G. Vigarello (dir.), De la Renaissance aux Lumières, in A. Corbin, J. J. Courtine, G. Vigarello (dirs) Histoire du Corps, vol. 1 Paris, Seuil, 387-409.

Vinagre, R. D. Diniz, E. M. A.; Vaz, F. A. C. (2001), "Leite humano: um pouco de sua história", Pediatria 23(4):640-645.

Vincent-Cassy, M. (1992), "La gula curiale ou les débordements des banquets au début du règne de Charles VI", in La Sociabilité à Table. Commensalité et Convivialité à Travers les Âges, Actes du Colloque de Rouen, 14-17 novembre 1990, Textes réunis par Martin Aurell, Olivier Dumoulin et Françoise Thelamon, Rouen, Publications de l'Université de Rouen: 91-102.

Vitolo, M. R. (2008), "Importância do aleitamento materno", in M. V. Regina, Nutrição da gestação ao envelhecimento, Rio de Janeiro, Rubio.

Wattel, O. (1998), Petit atlas historique de l'Antiquité Romain. Paris, Armand Colin.

Webster, J., Cooper, N. J., ed. (1996), Roman imperialism: post-colonial perspectives. Leicester, School of Archaeological Studies of University of Leicester (Leicester Archaeology Monographs 3).

Wecowski, M. (2002), "Homer and the Origins of the Symposion”, in F. Montanari (ed.), Omero tremila anni dopo. Edizioni di Storia e Letteratura, Roma, 627637. 
Who (1991), Indicators form assessing breastfeeding practices. Geneva, World Health Organization.

Who (2001), The optimal duration of exclusive breastfeeding, Geneva, World Health Organization.

Wilkins, J. M. and Hill, S. (20I I), Archestratus: Fragments from The Life of Luxury. Prospect Books. Totnes, Devon

Witt, Aracy (1971), "Alguns conhecimentos sobre nutrição ligados à gestação e ao puerpério", Rev Saúde Pública 5:97-102.

Woolf, G. (1990), "World-systems analysis and the Roman Empire", Journal of Roman Archaeology 3: 44-58.

Woolf, G. (1992), "Imperialism, Empire and the integration of the Roman Economy", World Archaeology 23 (3): 283-293.

Zevi, F. (1965), "Appunti sulle anfore romane. La tavola tipologica del Dressel", Archeologia Classica 18 (2): 208-247. 


\section{ÍNDICE ONOMÁSTICO}

\section{AnTropónimos}

Afonso Henriques: 115, 118

Ájax: 39

Alcínoo: 36

António Vieira, Padre: 245, 246

Aquiles: 39

Atena: 36, 37, 45, 58

Brómio/Baco: 33

Calipso: 38

Cambises: 30,37

Ceres: 44,58

Circe: 36,40

Ciro: 31

Deméter: 33, 35, 44, 58, 60

Eumeu: 39

Galeno: 146, 152, 287

Ganimedes: 37

Gláucon: 42, 43

Hefestos; 37

Hermes: 45

Hipócrates: 42, 146, 286

João IV, D.: 168, 225, 226, 229

Luís Álvares de Távora: 22, 219, 235, 241

Manuel I, D.: 119, 215, 217, 222

Máron: 30

Menelau: 36, 37
Mentes: 37

Nestor: 40

Pedro Álvares Cabral: 22

Pero Vaz de Caminha: 22, 23, 26, 27, 29, 30, 222, 289

Pisístrato: 36,38

Polifemo: 30, 32, 33, 49

Prexaspes: 37

Psamético III: 30

Sileno: 33

Sócrates: 42,43

Sorano: 287

Telémaco: $36-39$

Ulisses: 30, 32-34, 36-39, 49

Vasco Luís, D.: 213, 222, 225, 226, 228 , 229, 231, 234-237, 239, 240, 245, 246, 247, 250

Vicente Nogueira, D.: 213, 225-229, $231,232,234-246,248-50$

Zeus: 37, 38, 46, 48 


\section{ToPónimos/ETNóNimos:}

África:22, 51, 53, 54, 58-63, 65, 68, 114, $157,254,259,260,264$

Africano: 28, 54, 55, 65, 66, 247, 259$63,268,269,276,280$

Água de Runa: 122

Alentejo: 48, 90

América: 22, 254, 256, 261, 263, 270, 271

Ásia: 22, 47, 157, 260

Assafétida: 44

Atenas: 45

Bahia: 247, 265, 268, 281

Barcelona: 247, 265, 268, 281

Beirute: 49

Berberes: 23

Biblos: 49

Bizâncio: 43

Brasil: 18, 22, 24, 26, 50, 114, 156, 166, 169, 176, 177, 181, 185, 191, 247, 253, 254-73, 275-83, 285, 287, 28991

Brasileiros: 50, 254, 257, 259, 269, 272, 278

Calípolis: 42

Ciclopes: 30,32

Coimbra: 17, 34, 47, 71, 89, 97, 113-27, 121, 130, 131, 133-36, 172, 189, 192-96, 199, 211, 225, 237, 242

Cólofon: 40

Egeu: 39, 65

Egipto: 30,80

Eiras: 118,125

Éreso: 45

Éritras: 45

Etíopes: 30, 31

Europa: 40, 47, 72, 81, 114, 127, 154, 156, 211, 213, 256, 259, 260, 261, 289

Évora: 90, 94, 97, 117, 127, 154, 156, $162,169,170-72,175-80,184,185$,
$187,189-192$

Fenícia: 46, 49, 58, 59, 61

Gregos: 19, 23, 25, 29, 32, 35, 38-40

Hélade: 47

Icária: 40

Índia: 22, 41, 103, 114, 156, 172, 177, 179, 180, 211, 228, 239, 247, 259, 268,286

Ítaca: 30,32

Itália: 60, 65, 72, 143, 210, 222, 227, 231,245

Lâmpsaco: 42

Lesbos: 45, 46, 48

Lisboa: 48, 72, 90, 91, 93, 97, 100, 101, $103,116,118,141,154,156,158$, 165-92, 196, 200, 213, 216, 220-22, $225,228-30,232-34,238-40,242-$ 50

Livorno: 231, 243-246

Madeira: 26, 105, 152-55, 177, 179, 217, 220, 259, 261

Mar Negro: 19

Masságetas: 31, 34

Mauritânia: 23

Mediterrâneo: 19, 32, 52, 59, 65

Mênfis: 30

Mondego: 115, 116, 127, 136, 199

Montemor-o-Velho: 48, 91, 97, 174

Náucrates: 38, 47

Novo Mundo: 22, 26, 50

Oliveira de Azeméis: 48

Oriente: 26, 59, 114, 156

Palma: 105, 214

Península Ibérica: 81, 107, 134, 222, 261

Pernambuco: 176, 188, 191, 247, 268

Persas: 30,31

Pérsia: 30, 31, 41, 222

Pilos: 38

Porto Seguro: 23

Portugal: 17, 18, 20, 26, 32, 40, 48-50, 
99, 107, 109, 114, 115, 119, 127, $130,136,143,145,147,152-54$, $157,159,162,165,166,172,176-$ $178,183,196,199,213,214,217-$ 19, 226, 228, 229, 242, 246, 250, 253-65, 267-69, 288

Portugueses: 19, 24, 26, 27, 31, 50, 100, $108,1142,144,155,157,202,213$, 214, 219, 222, 225, 226, 245, 24750, 256-70, 273, 276, 281, 289, 290

Real Colégio de São Pedro de Coimbra: 193, 194, 196, 203, 211

Roma: 52, 55, 61, 62, 64, 65, 213, 225, 230, 244-46, 287

Romanos: 25, 44, 50, 51, 53-56, 59, 61$63,146,259,272$

Rua de Oleiros: 122

Rua dos Confeiteiros: 173, 174, 221, 249

Santa Clara: 91, 116, 118, 153, 239, 240, 246

Santa Cruz: 115, 116, 130

Santa Justa: 115, 116, 121, 122, 125-31, 134,169

Santiago:115, 116, 122, 123, 130, 176

Santo António dos Olivais:118, 185

São Bartolomeu: 115, 116, 122, 123 , $128,130,131,132,134,135$

São Martinho do Bispo: 118

São Paulo de Frades: 118

São Tomé: 26, 177

Sé de Coimbra: 122, 125-27

Sicília: 43, 55, 105, 152

Sinai: 41

Táfios: 37

Tasos: 45,49

Tégea: 45

Terena: 48

Tessália: 45- 46

Tomar: 48, 219, 232

Tripoli: 49

Tupiniquins: 23, 24, 26, 27, 29, 30
Valongo: 48

Vaqueiros: 48

Vera Cruz: 22 


\section{Alimentar (alimentos)}

abetardas: 119

abóbora: 176, 177, 179, 201, 216, 217, 218, 219, 221, 247, 249, 250, 258.

açafrão: 103, 114, 136, 197, 209.

acelga: 258 .

acepipe: 43, 264.

açúcar: 24, 25, 26, 97, 105, 120, 152, $153,154,156,158,167,173,175-$ $81,197,203,213-23,227-32,234-$ 39, 241, 244, 247, 254, 256, 261, 265, 281, 182, 283.

açúcar cristalizado: 25

açúcar de panela: 105

açucar em pão: 105

açúcar rosado: 24, 25, 175, 176, 179, $215,221,229,231,234,247,250$

aeromeli: 41

agrião: 258

água: 23, 26, 27, 29, 37, 38-41, 55, 63, 82-84, 93, 101, 102, 105, 107, 109, $120,122,136,148,156-58,161$, 199, 215, 219, 223, 226, 237, 238, 277,282

água de flor: 26, 227

álcool: 283,284

alecrim: 258

alfavaca: 258

alfenin: 176

alforge: 38

alho: 42, 120, 136, 151, 201, 258, 259, 285

almôndegas: 102

ambrósia: 46, 49

ameixas: 120, 210, 215, 216, 218, 232

amêndoa: 24-26, 105, 120, 167, 175$177,179,232,233,250,256,264$

ananás: 156

animais domésticos: 39

animais selvagens: 39,60

anis: 25 aperitivo: 44

aprovisionamento, 38, 94, 97, 150

arenque: 104

arroz: 27, 151, 197, 201, 208, 210, 257, $258,280,282$

arroz de pato: 271

arroz doce: 166, 226, 265, 280, 281, 291

árvore: 29, 44, 126, 151, 229, 280

atum: 42, 43, 150

aveia: 120

avelãs: 120

aves: 43, 44, 101, 103, 119, 197, 198

azeite: 41, 43, 46, 52, 59, 63-67, 113, 119-24, 130-32, 136, 156, 196, 202, 211, 257, 264, 266

azeitona: 21, 42, 44, 63, 101, 137, 223, 226

azevia: 104

bacalhau: 150, 197, 199, 210, 257

bagaço: 101, 122

baganha: 122, 123, 131

banana: 260,265

banha: 119, 185, 197, 202, 210, 263

batata: 114,156

bebidas fermentadas: 259

beiju: 263, 264

beilhó: $26,151,265$

beringela: 258

besugo: 104

biblino (vinho): 46, 49

bodalo: 104

boga: 104

boi: 29

bolbo: 42,151

bolo: 25, 26, 167, 185, 254, 261-65, 271, 281

bolota: 42, 101, 120

bouquet: 49

bovinos: 39, 286

broa: 21,263 
cabra: 29, 39, 40, 264, 280, 281

caça: $39,44,54,58,90,92,98,102,107$, $119,120,136,149$

cação: 104

cacho: $35,45,46,58$

cachucho: 104, 199

caju: 264,265

cana de açúcar: 26, 105, 152, 214, 217

canafístula: 120

canela: $26,103,114,120,156,259,266$

canja de galinha: 280, 282, 291

canjica: 260, 263, 280-82, 291

caprinos: 29,286

carimã: 264,265

carne: $30,33,36-39,55,58,72,85,98$, 101-04, 113, 114, 119, 120, 124, $125,130,132,134,136,144,148-$ $50,150,156,157,159,172,197-99$, 206, 207, 218, 227, 237, 238, 247, $257,258,260,263-65,282,285$

carneiro: 119,135, 149, 197, 198, 210

carnes frias: 39

casquinhas: 218,219

castanhas: 120, 208, 210

castas: 48

cauim: 259

caule: 44

cebola: 40, 120, 136, 151, 201, 258, 259, 265

cebolinha: 259

cenoura: 201, 258

centeio: 120,127

cereal: 29, 31, 40, 44, 45, 101, 118

cerejas: 120,151

cerveja: 161, 280, 283, 284

cevada: 32, 39, 40, 42, 45, 46, 120, 127, 149,154

cheiros: 103, 228, 238, 257, 258

chicória: 197, 210, 258

chocolate: 156

chocos: 104 chouriço: 21

chuchu: 258

cidra: $120,177,217,222,228,260$

cidrada: 167, 219, 226-28, 235, 237, 238, 247, 249

cidrão: 26,250

cinamomo: 103

coco: 260, 261, 264, 174

coelho: 103, 119, 120, 149, 185

coentro: 197, 203, 210, 126, 258, 266

cominho: 43, 111, 259

compota: 200, 223, 241, 262, 265

condimento: 97, 103, 120, 136, 195, 197, 201, 203, 206, 209, 257

conduto: 23, 38-40, 42, 43

confeitaria: 24, 25, 165-67, 169-71, 173-79, 181, 216, 220, 221, 239, 261,271

confeiteiro: 24-26, 163, 165-86, 192, 213, 214, 217, 218, 220, 221, 226, 232, 247-49

confeito/confeite: 23-25, 102, 105, 166, $175,176,179,185,215,221,222$, 223, 226, 231-33, 236, 249, 250

confraria (gastronómica): 20, 48, 59, 184, 185

congro : 104, 199

conserva: 21, 102, 105, 151-53, 158, 166, 167, 1696, 175, 176, 179, 200, 213-50, 260, 263

cordeiro: 119

couve: $201,258,265,268$

cravo: 25, 26, 103, 114, 156, 259, 266

creme: 26

dendê: 260

diacidrão: 176, 217, 218, 222

doçaria: 26, 48, 153, 166, 167, 172, 176, 179, 198, 220, 222, 223, 241, 256, $257,260-62,264$

doce: 23-26, 30, 39-41, 102, 105, 114, 149, 152, 153, 157, 166-68, 172, 173, 175-77, 179, 183, 186, 197, 
199, 200, 210, 213-15, 217, 222, $223,225-50,254,256,259-62,265$, $267,280,281,291$

droga: 31, 35, 40

empadas: 102, 104, 150, 151

enchido: 43, 103

endro: 258

enguia: 104

ervas (aromáticas): 26, 46, 101, 103, 152,203

especialidade (gastronómica): 20, 25, $42,43,271$

especiaria: 26, 97, 103, 114, 120, 136, 156, 203, 209, 216, 257, 259, 261, 281

espiga: 45

espinafre: 197, 198, 207, 210

faneca: 104

farinha: 45, 46, 127, 154, 254, 256, 257, $259,261,264,265,281,282$

farinha de cevada: 45

farinha de trigo: 45, 127, 261, 265

farofa: 258,265

fartem/fartéis/fartes: 23-26, 167, 179, 247,256

fava: 42,43

feijão: 197, 201, 210, 257

figo: 23, 26, 42, 43, 58, 120, 260

figo seco: 43

filhós: 26, 37, 181, 278

flos vini: 49

folhados: 26

frango: 151, 197, 198, 207, 210

fruta: $23-25,30,54,55,58,59,97$, $101,102,104,105,114,118,120$, $126,149-152,157,159,166,167$, 174, 176, 177, 195, 197, 200, 201, 208, 210, 214, 216, 218-23, 226-28, 231, 237, 238, 257, 259, 260, 261, $265,280,281,285$

frutos secos: 26

frutos silvestres: 42 funcho: 258

gado: 29, 31, 32, 101, 119, 120, 136, 197

gado bovino: 39, 120, 197, 286

gado caprino: 32, 39, 120, 286

gado ovino: 32, 39, 120, 197, 286

gado suíno: 39, 120, 197

galhuda: 104

galináceo: 198, 282

galinha: 29, 119, 120, 149, 197, 198, 207, 210, 257, 260, 265, 280, 282, 283

geleia: 223, 241, 281

gengibre: 26, 103, 105, 114, 259

ginja: 228, 231, 234

goma de cedro: 25

goraz: 104,199

gordura: 63, 119, 120, 122, 196, 202, 203, 237, 260, 263

grainha: 45

grão: 40, 45, 46, 61, 84, 101, 197, 201, 210, 217, 263

grão-de-bico: 42, 43, 268, 281

grous: 119

hortaliça: 114, 120, 126, 137, 152, 197, 201, 208, 210, 258

iguaria: $23,24,26,31,37,38,43,50$, 102, 104, 110, 151, 218, 222, 223, 228,247

inhame: 29

lacticínio: 119, 120,196

lagosta: 104

lampreia: 104, 150, 151

laranja: 114, 120, 167, 228, 247

lebre: 120

legume: 29, 31, 84, 114, 118, 120, 125, 126, 132, 136, 151, 152, 197, 201, 208, 209, 218, 222, 223, 282

leite: $25,30,32,33,42,151,157,196$, 211, 212, 218, 226, 276-88, 290, 291

leite de cabra: 264,280 
leite de coco: 261,264

leite de vaca: 264,280

leite fraco: 276, 285, 290, 291

leite humano: 277, 281, 287, 290

leite materno: 277, 278, 280, 282-84, $286,287,291$

leiteiro: 25

lentilha: 120

lésbio (vinho): 46, 49

limão: 218, 260

língua de vaca: 197, 198, 210

linguado: 104, 197, 199, 210

lombo: 103,210

louro: 259

lula: 104

malvasia: 105

maná: 41

mandioca: 256, 259, 261, 265

manjar: 103, 109, 150, 151, 163, 167, $196,212,218,226,256$

manjericão: 258

manteiga: 119, 120, 167, 185, 196, 197, 202, 210, 263

maracujá: 265

marisco: 41, 102, 119, 136, 149

marmelada: 25, 153, 167, 175-177, 179, 215, 216, 218, 219, 221, 223, 228, 230, 231, 234-36, 238-41, 247, 24750,265

marmelo: 105, 177, 223, 228, 247, 260, 265

massa: 25, 26, 167, 228, 281

massapão: 24, 175, 176

mel: 26, 30, 31, 39, 40-42, 119, 120,170, $177,219,221,224,229,231,234$, 261,265

melancia: 260

melão: 249,260

mezinhas: 152, 202, 214, 218, 219

milhete: 59, 60

milho: 21, 114, 119, 120, 127, 257, 259,
263-65, 281, 282

mimos: 213, 223, 224, 234

mingau: 265, 281

mirra: 43

moreia: 104

mungunzá: 281

murta: 42

nabo: $197,210,258$

néctar: 49

nozes: 120

noz-moscada: 259

óleo: 215,260

óleo de palma: 265

oliveira: 118

ostras: 104,184

ovelha: $29,33,39,286$

ovino: 39,286

ovo: $26,101,120,149,151,167,197$, 198, 210, 238, 249, 257, 260, 261, 266, 281, 285

ovos de galinha: 257,260

ovos de jacaré. 260

pão: 17-29, 31-50, 52, 55, 82-85, 98, $101,102,105,111,113,114,120-$ $23,125,127,128,136,143,144$, 148, 154, 155, 156 167, 175, 198, 201, 201, 206, 208, 210, 256, 259, 263

pão branco: 45, 46, 154, 259

pão caseiro: 46

pão comercial: 46

pão escondido: 45, 46

pão kondrinos: 45, 46

pão krimnites: 45, 46

pão ralado: 25

papa: 198, 263, 266, 277

pasta: 42, 167, 177, 183

pastel/pastéis: $102,150,151,167$

paté: 42

pato: $197,210,260,271$ 
peixe: 42, 103, 104, 113, 114, 119, 124, $125,132-34,136,149-51,159,162$, 197-200, 207, 208, 210, 211, 226, $257,258,260,271,282,285$

peixe fumado: 197, 199, 210

peixe seco: 104,260

pelames: 116

pepino: $210,216,218,258$

pêra: 120, 151, 176, 179, 217, 221, 237, $249,250,265$

perada: $218,219,226,229,230,235-39$, 249,265

perdiz: 103, 119, 120, 149, 224

peru: $156,197,210$

pesca: 124,132

pescada/pescado: $23,43,101,102,104$, 132-34, 136, 149, 150, 197, 199, 210, 285

pessegada: 218, 219, 230, 231, 234, 236, 238

pêssegos: 151, 176, 217, 219, 219, 228, 230

petisco: 43

pimenta: 26,103, 114, 119, 120, 136, $156,259,271,285$

pimenta malagueta: 259

pimenta-do-reino: 259

pinha: 25

pinhão: 25, 26, 210, 265

pinheiro: 25

pinhoada: 167, 247, 265

pirão: 258,265

polvilho: 261

pomba: 119

porco: 39, 43, 44, 103, 119, 148, 181, $185,197,198,207,210,257,258$, $263,264,282,285$

porco do mato: 258,264

porco europeu: 257

porco ibérico: 264

presunto: $21,27,103$ queijo: 21, 32, 33, 39-42, 46, 48, 55, 119, 120, 157, 196, 211, 212, 215, 223, 226

queijo curado: 120

rábano: 102, 201, 258

ração: 42, 43, 63

raiz: $101,142.151,259,263,269$

rebanho: 33

repasto: $31,38,107,247$

repolho: 197, 210

rodovalho: 104

rola: 119

romã: 58-60, 106

rosa: $25,58,59,60,176,228,234$

ruibarbo: 120

ruivo: $197,199,210$

sal: 39, 43, 44, 97, 149, 197, 210, 257, 260, 282

salmonete: 104

salmoura: 44, 260

salsa: 258

sama: 104

sardinha: 104, 149, 150, 197-99, 210, 257,258

sargo: 104, 199

sarrabulho: 271

sílfio: 43,44

sobremesa: $23-26,42,43,105,151,153$, 166

solho: 104

sonhos: 198, 263, 266, 280

sopa: $198,263,266,280$

suíno: 39

talos de alface: 218, 247, 250

tâmara: 41, 106

tamarisco: 41

tásio (vinho): 46

teta de porca: 43,44

tomate: 156

tordo: 197, 198, 210 
tortas: 102,226

toucinho: 148, 149, 167, 196, 197, 202, 210, 266, 268

tremelga: 46

trigo: 29, 31-33-42, 45, 46, 61, 119, 120, 127, 149, 154, 257, 259, 261, 264, 265

truta: 104

uva: 33, 45, 58, 120, 257, 259, 260

vaca: $29,102,103,119,148,149,197$, 198, 207, 210, 211, 264, 280, 286

veado: 39,119

vegetal: 51, 55, 202, 283, 291

veneno: 31,35

verdura: 92, 118, 195, 197, 201, 206, 208, 209, 258

videira: 32,40

vinagre: 43, 197, 202, 209, 211, 286

vinha: 32, 46, 92, 119, 122, 126, 136, 180

vinho: $17-23,25,27,28,3-50,55,101$, $102,104,105,107,113,114,118-$ 20, 124, 128-30, 132, 136, 143, 144, 148, 154-56, 158, 160, 161, 197, 201, 202, 206, 209, 211, 226, 257, 259

vinho de pramno: 40

vinho de uvas: 259

vinho puro/estreme: 31, 31, 41

vinho tinto: 155

víscera: 4 


\section{Produção}

(técnicas, objetos e processos)

abate: $31,39,134$

acondicionamento: 219, 227-229, 234$36,239-43,248$

açucareiro: 105

agomis: 107

albarrada: 23

ânfora: 49, 52, 64, 65

assado: 73, 237, 257, 262, 263, 281

assar: 102, 261

assento: $40,108,130,136$

bacia: $19,37,50,179$

baixela: $54,96,107,110$

banquete: 31, 38, 41-43, 54, 58, 60, 96, $97,102,106,108,110,145,152$, $156,158,159,222,223,226,249$, 256,262

bar: 21

botica: 214, 215, 238, 243

brasido: 43

caça: $39,44,54,58,90,92,98,102$, $107,119,120,136,149$

caçada: $39,55,59,61,93,102,105,110$

cadeira: $27,40,180$

caixas: $177,179,180,181,219,228-31$, 233-36, 240-42, 248, 249

caldeira/caldeirão: 72, 103

caldo: $215,260,263,283$

cantina: 21

cardápio: 24, 218, 256, 267

cesto: 39,40

conservar: 169, 218, 219, 220, 288

convívio: 20, 36, 37, 48, 106-108, 110, 272

copa: 98, 107-10, 116

cozinha: 21, 24-26, 35, 38, 51, 52, 71, $75,89,91-94,96,98,100,103,104$, $119,120,142,143,148,149,151$, $158,163,171,179,193-96,201-03$, $211,213,218,223,226,238,253-$
$58,261,263,264,266-68,270-72$

cozinhado: 149, 263

currais: 92, 113, 121

curtição: 116

delícia; 31, 45

ensopado: 266

entradas: 21,44

escalfado: 263

esmagar: 42

estufado: 46

farnel: 21,38

fogão de abóboda: 262

fogão de chapa: 262

forno: 45, 46, 113, 121-23, 127, 136, 262,268

fornos de pão: 113, 121, 122, 136

frigideira: 262

fritura: 260,262

fogo: 43, 51, 85, 87, 122, 219, 238, 260, 262

fruteiro: 25

fumeiro: 263

garrafão: 21

grelha: 43, 73, 149, 215, 262

grelhar: 75

guisado: 257,263

krater: $34,41,47$

kylix: 41

jarra/o: 31,37

líquido: 41, 63, 156, 227, 241, 263, 277, 280, 285, 291

livro de cozinha: 148, 181, 193, 196, 218

mamadeira: 277, 286, 289

menu: 21, 23, 31, 38, 41, 42, 152, 257

mesa: 17, 18, 20, 23, 25, 27, 35-42, 44, $46,47,50-52,55,56,58,59,67$, $73,89,94,96,97,100,102-104$, 106-111, 114, 141, 142-45, 147-63, $166,167,180,183,186,188,191$, 194-96, 198, 200, 212, 216, 221- 
23, 226, 227, 234, 247, 249, 250, 256, 281

moagem: 45

moinho: 127,136

moquém: 260

objectos da mesa: 89

odre: 38

olaria: $64,116,242$

padaria: 25,221

panela: 105, 221, 229, 236, 238, 262

panos: $96,103,107,228$

pastelaria: 21,25

pesos: 156,167

phiale: 41

piparote: 105, 155, 221, 224

pisado: 73,119

poia: $123,127,128$

pomares: 92, 118

praça/ mercado: 45, 46, 63, 65, 66, 118 , 119, 130, 136, 144, 211, 216, 231 , 232

prato: $20,21,23,25,39,42-44,54,56$, $58,59,89,100,102-104,150,153$, $158,159,184,223,235-37,256$, $260,265,267,271,281$

preparação: $39,40,42,43,73,124,125$, $134,154,172,173,177,186,218$, 219, 222, 223, 227, 235, 281, 282

purificação: $37,41,78,80$

raça: $267,269,272$

ralador: 40

receita: 20, 24-26, 43, 149, 151, 196, 202, 214, 218-220, 222, 223, 232, $241,254,256,262,265,271,281$, 283

restaurante: 21

salva: $37,180,224,241$

serviço de mesa: 36, 40, 44

taberna: 21

tabuleiro: 48

taça: 37, 41, 44, 107, 241 tainha: 104, 197, 199, 210

tapeçarias: 98, 107

tasca: 21

toalha: $27,107-10,167,180,247$

utensílio: 41, 97, 179, 257, 262, 277, 286

vaso: $37,41,64,179,235,239,286$ 


\section{Ofícios/Mesteres}

açougue: 129, 130, 134, 136

alcacel: 127

alfoz: 117

alitães: 104

almocreves: 116,125

almotacé: 119

alveitar: 98

arauto: $97,98,110$

armeiro: 107

azeiteiro: 131

azemel: 98

caçador: 59,98

caminheiro: 98

camponês: 55, 117

carniceiro: 98, 113, 134, 135

cavalariço: 98

comerciante: $116,124,125,130,136$, 287

comprador: 97, 98, 100,101, 103, 104

confeiteiro(a): 24-26, 163, 165-87, 192 , 213, 214, 217, 218, 220, 221, 226, 232, 247-49

conserveira: 169, 214, 231, 235, 238, $239,246,249$

conserveiro: 214

copeiro: 26, 97 100, 163, 214

cozinheiro: $25,26,98,100,101,104$, $163,222,256,267$

despenseiro: 25,97

dispensa: 19, 40, 96, 98, 103, 105, 130

doceiro: 25

enxerqueiras: 125

escanção: 37

escançaria: 104

escravo: 42, 54, 88, 166, 254, 269

escrivão da cozinha: 100

escudeiro: 37, 100, 103

falcoeiro: 98

ferrador: 98 guarda-resposte: 215,224

governanta: 37,38

homens de pé: 98

intendente: 33

jogral: 97,110

lagareiro: $113,130-32$

lagar de azeite: 113, 121-23, 129-31, 136, 137

magarefe: 134,135

manceba: 98, 101, 175

manteeiro: 96

marchante: 134

marisqueira: 125

mercador: 116, 125, 173, 242, 244

merceeiro: 125

mestre do relógio: 97, 98

metalurgia: 119

moço de câmara: 98, 101

moço de cozinha: 163

moço do monte: 98

moleiro: 127

negro/negra: 110, 146, 154, 238, 239 , 259, 260, 269, 271, 279, 282, 289

oficiais: $89,94,96,98,100,110,167$, $169,175,183,220$

olival: 118,180

padeira: $125,127,128$

panificação: 124,127

pasteleiro: $25,163,166-69$

peixeira: 125

periliteiro: 97,98

porqueiro: 39

regateira: 125

regueifeira: 98, 100, 101

reposte: $97,98,153$

reposteiro: 96, 97, 98, 100, 101, 107, 224

sapateiro: 98, 173, 180

sardinheira: 125

servo(a):35, 37, 42, 86 
Índice onomástico

serviçal: 37

tendeiro: 175,182

tesoureiro: 103-05, 153

trinchador: 37

trinchante: 163

trombeteiro: 97,110

uchão: 97

ucharia: 96, 148, 149, 163, 257, 267

vedor: 96, 100, 103, 108, 217

vendedeira: 125

verceira: 125

vinhateiro: 113,12 



\section{Índice Comum}

abelha: $25,173,261$

abstinência: 78, 79, 82-84, 87, 104, 149, 150

aculturação: 50

africano: 28, 54, 55, 65, 66, 247, 259-63, $268,269,276,280$

alcáçova: 90-92, 116, 151, 162, 193

aleitamento artificial: 288

aleitamento materno: 275-79, 281, 283, 285-87, 289-91

algazaria: 119

alimentação mediterrânea: 34

alimentação portuguesa: 34, 49, 50

almedina: 115, 116, 123, 127, 129-31, 134,136

almoço: 157

almuinha: 118, 126, 127, 137

amamentação: 169, 275-79, 283, 284, 286-91

ama de leite: $286-289$

anfitrião: 20,37, 54

antiguidade: 17, 22, 29, 35, 39, 47, 50, $52,58,61,65,152,200,266,290$

arrabalde: 91, 115-17, 122, 129, 130, 134, 136

astrologia: 146, 147

atrium: 55

audiência episcopal: 123, 126, 131 banquete(s): 31, 38, 41-43, 54, 58, 60, $96,97,102,106,108,110,145,152$, $156,158,159,222,223,226,249$, 256, 262

bebé: $284,286,288$

bestialidade: $22,28,33$

bodas: 108,109

botânica: 22,44

brindar: 48

burguesia: 288

caloria: 284

canibalismo: 32, 33

carboidratos: 284

carta de quitação: 103, 104

casa corrente: 120

Casa da Rainha: 94, 96, 100, 101, 153, 217

Casa do Rei: 94, 96, 100. 105

Casa Real: 96-98, 102, 104, 105, 107, $110,155,159,163,217,220,256$, 257

cavalariça: 121

ceia: 77, 102, 157, 158, 162, 237, 256, 271

celebração: 20, 36, 147, 155

cena: 19, 36-38, 54-56, 58, 72-74, 107, 157

cerimónia: 90, 108, 110, 159, 162, 260 
civilização: 20, 39, 50, 54, 67, 156, 163, 238

civilizado: 18, 22, 29-32, 34, 39

colegiada: 115, 121-123, 125-32, 134, 135

colegial: 194-97, 203, 212

colégio: 59, 176, 193-95, 199, 200, 203, 211

colónia: 26, 65, 166, 169, 262, 270, 276, $283,289,291$

colonial: 26, 65, 166, 169, 262, 270, 276, 283, 289, 291

colono: 29, 32, 62, 260, 263

concelho: $114,118,156$

Condes portucalenses: 115

conquista: 115,118

consoada: 198

convalescência: 282

convalescente: 238,282

convidado: 20, 54, 55, 58, 77, 106, 110

cortes: 90, 97, 108, 145, 256

crença, 29, 67, 68, 74, 142, 214, 257, $275,276,278,279,280,282-84$, 290, 291, 292

criança: 166, 167, 169, 277, 278, 280, 282, 286-88, 290

cultura: $17-20,23,27,28,50,52,53,54$, $61,66-68,74,77,80,81,108,110$, $113,119,126,127,142,152,165$, 166, 214, 222, 224, 254-56, 268, 270, 276, 278-81, 285

cultura portuguesa: 19, 30, 247, 253

descobrimentos: 23

desmame precoce: $278,287,290$

desnutrição: 278

diaita: 278, 287, 290

dieta: 17, 19, 22-24, 29, 31, 32, 35, 36, $42,44,50,55,58,67,113,119,123$, $151,194,195,196,201,203,222$, 237, 256-58, 260, 261, 265, 279, 282, 284-86, 291

dieta europeia: 19 dieta mediterrânea: 24, 35, 50

dieta portuguesa: 19, 32, 265

dízimo: 123, 126, 128, 131

domus: 53, 56, 67

embriaguez: 283

estereótipo: 28'

estômago: 43, 52, 71, 75, 77, 78, 82, 84, $85,87,88,237,267$

exedra: 53, 56, 57, 67

família: 20, 37, 46, 53, 55, 56, 79, 105, $113,127,136,172,178,216,219$, 246, 271, 277, 279, 283, 284, 287, 289

faraó: 30

fauna: 114,257

fera: $22,31,33$

fertilidade: $58,118,277,290$

festa: $20,21,26,48,97,106,110,143$, $154,155,158,166,250,256,281$, 289

fisiologia: 51, 73, 77, 277, 278, 283, 285

flora: 114,257

fome: $51,73-76,80,82,83,145,158$, $160,264,278$

foral: $115,116,118-20,122,130,133$

freguesia(s): 122, 123, 125, 127-29, 131, $132,134,168,174$

frio: $21,27,150,162,226,281,185$

gastronomia: 20, 23, 35, 52, 150, 156, $163,213,218$

gastrónomo: 47, 51

gourmet: 44

gravidez: 282

grinalda: 43

herança colonial: 270. 276, 291

higienização: 41

hipogalactia: 278

horta: 92, 113, 121, 258

hospitalidade: $30,32,36,51,53$

identidade: 17, 20-22, 24,29, 30, 36, 49, $50,68,165,195,201,247,250$ 
iguador: 98

imus lectus: 56

incenso: 41, 43

indígena: 29, 257, 259, 260, 261, 262, $263,281,288$

índio: 22, 23, 27, 29-31, 222, 263, 269, $270,272,273,279,281,288$

ingestão: 31, 38, 72, 78, 215, 237, 284

inventário: 142, 178, 179, 214, 215

jantar: 48, 51, 54, 56, 102, 106, 157, 158, 222, $226237,256,261$

jejum: 78, 84, 104, 149, 157, 162, 195, $211,215,271$

jentaculum: 55

lactação: 277, 278, 281, 285, 286, 288, 290, 291

lactogogo: 276, 278, 279, 281-84, 291

lanche: 21

lazer: $21,93,157$

leitoso: 280

limpeza: 41, 219, 223, 250

ludus / ludi gladiatorii: 59

lusofonia: 18, 19, 50, 237, 281

mãe: 31, 43, 153, 170, 171, 178, 215, 222, 276-80, 286-90

mama: 277,290

mamilos: 288,290

mantimento: $22,23,26,30,89,154$, 162,266

manuscrito: 25, 73, 74, 214, 218, 219, $232,235,241$

maternidade: 287,290

materno : 172, 275-91

medicina: 146, 150, 152, 162, 163, 194, $214,215,237,254,283$

medicina galénica: 150,152

medida: 31, 63, 119, 156, 209

medius lectus: 56

mercenárias: 288, 289

merenda: 21, 157, 158, 223, 250

mesa régia: $89,104,144,145,159,161$,
221

mito: $39,51,52,54,58,275,276,278$, $279,285,290-92$

monarca: 22, 37, 89-94, 96, 100, 102, 106-08, 114, 116, 118, 120, 130, 133, 145, 146, 154, 157, 158, 162, 220,225

monarquia: 145, 147, 154, 159, 162

monteirinho: 98

mortalidade infantil: 277, 286, 288, 289

mos maiorum: 58,67

mulher: 40, 97, 98, 100, 125, 128, 137, 154, 160, 166, 167, 169, 172-75, $177,178,182,185,186,233,247$, $265,277-84,286-92$

natal: $100,106,167,195,223,224,230$, $246,247,254,264$

nómada: 31,32

núcleo amuralhado: 115

nutrição: 76, 254, 258, 267, 278, 287, 291

nutricionista: 267,275

nutriente: 38, 277, 284, 290, 291

nutriz: 276-79, 282, 284, 285, 290, 291

ostentação: 54, 58, 107, 144, 145, 147, 156, 158, 159

padrão alimentar: 22, 26, 30, 31, 32, 34, 50

palácio: 36-38, 89, 93, 236

paladar: 48, 103, 227, 256, 263, 264, $265,267,271$

parida: 282

parto: 282, 286, 287

parturiente: 207, 279, 283, 285

pastor: 32

património alimentar: 17, 49, 50, 237

património imaterial: 17,20

perfume/fragrância: 43, 58

perystilum: 55

posturas de 1145: 118, 119

prandium: 55 
primitivismo: 28

primitivo: $22,27,29,39,32,50,74$

proibições: 52, 282

propriedade urbana: 115

proteínas: 198, 207, 267, 284, 287

provisões: 38,257

puérpera: 282

quente: 43, 48, 59, 134, 146, 226, 282, 285

receita: 20, 24-26, 43, 149, 151, 196, 202, 214, 218-20, 222-24, 241, 254, $256,262,265,271,281,283$

refeição: 19, 19, 21, 23, 36, 37-40, 45, $48,55,58,101,102,105,107,110$, 157, 158, 162, 163, 221-23, 226, 262

regime enfiteutico: 123

regimento: $162,169,171,176,220,221$, $223,242,243$

regionalismo: 272

relego: 120

remédio: $35,82,82,236$

resguardo: 98, 276, 282-85, 288

restrição alimentar: 276, 284

saúde: $27,29,35,38,42,48,77,83,146$, $147,150,160,162,277,278,287-$ 89

seios: $278,288,284$

selvagem: 22, 27, 30-32, 39, 44

sepultura: 284

sibas: 104

silvestre: 17, 22, 23, 29, 31, 42, 50

simbólica alimentar: 147, 148

simpósio: 48

sobrevivência: 38, 51, 62, 178, 195, 286, 288, 289

soldalitas: 59

summus lectus: 56

tabu : 48, 260, 275, 276, 278, 279, 284, 285, 291, 292

teoria dos humores: 150, 162 terroir: 48,49

Tribunal do Santo Ofício: 24, 165, 166, 171

Triclinium: 55, 56

turismo: 20

UNESCO: 17,20

Utensílio: 41, 97, 179, 257, 262, 277, 286

útero: 277

venatio: $59,60,68$

veneno: 31,35

villa: 67

vínculo afetivo: 272, 287

xenia: $32,36,51,53,54,56,67,68$ 